\title{
CONSUMO, PARÂMETROS DIGESTIVOS E COMPORTAMENTO DE BOVINOS DE CORTE EM PASTEJO DE CAPIM TANZÂNIA (Panicum maximum Jacq. cv Tanzânia) SUPLEMENTADOS COM FONTES DE ENERGIA OU DE PROTEÍNA
}

\author{
RICARDO PEREIRA MANZANO \\ Médico Veterinário
}

Orientador : Prof. Dr. LUIZ GUSTAVO NUSSIO

\begin{abstract}
Tese apresentada à Escola Superior de Agricultura "Luiz de Queiroz", Universidade de São Paulo, para obtenção dos título de Doutor em Agronomia, Área de Concentração: Ciência Animal e Pastagens.
\end{abstract}




\section{ERRATA}

Autor: Ricardo Pereira Manzano

Titulo: Consumo, parâmetros digestivos e comportamento de bovinos de corte em pastejo de capim

Tanzânia (Panicum maximum Jacq. Cv. Tanzânia) suplementados com fontes de energia ou de proteína.

$\begin{array}{llll}\text { p. } & \text { item } & \text { linha } & \text { onde se lê } \\ 67 & \text { Tabela 6 } & \text { R1 } & 0,86(0,20 \text { a 1,51) } \\ 67 & \text { Tabela 6 } & \text { Ri } & 0,91(0,36 \text { a 1,72) } \\ 67 & \text { Tabela 6 } & \text { R1 } & 0,16(-1,08 \text { a 1,71) } \\ 67 & \text { Tabela 6 } & \text { R2 } & 0,95(0,31 \text { a 1,75) } \\ 67 & \text { Tabela 6 } & \text { R2 } & 0,75(0,82 \text { a 1,18) } \\ 67 & \text { Tabela 6 } & \text { R2 } & 0,31(-0,43 \text { a 1,98) } \\ 86 & \text { Tabela 13 } & \text { NDT } & 59,28 \\ 86 & \text { Tabela 13 } & \text { NDT } & 59,80 \\ 86 & \text { Tabela 13 } & \text { NDT } & 0,9593 \\ 86 & \text { Tabela 13 } & \text { NDT } & 0,7089 \\ 86 & \text { Tabela 13 } & \text { NDT } & 0,5992 \\ 86 & 3.3 .3 & \text { Oitava e nona } & 0 \text { NDT não sofreu efeito do } \\ & & & \text { residuo..... } \\ 91 & \text { Tabela 14 } & \text { NDT } & 60,81 \\ 91 & \text { Tabela 14 } & \text { NDT } & 58,89 \\ 91 & \text { Tabela 14 } & \text { NDT } & 60,03 \\ 91 & \text { Tabela 14 } & \text { NDT } & 58,43 \\ 91 & \text { Tabela 14 } & \text { NDT } & 1,3482 \\ 91 & \text { Tabela 14 } & \text { NDT } & 0,2931 \\ 91 & \text { Tabela 14 } & \text { NDT } & 0,5446 \\ 91 & \text { Tabela 14 } & \text { NDT } & 0,5568 \\ 91 & \text { Tabela 14 } & \text { NDT } & 0,4247 \\ 91 & \text { Tabela 14 } & \text { NDT } & 0,2313 \\ 93 & \text { 3.4 } & \text { Primeira } & \text { A disponibilidade de matéria seca da } \\ & & \text { segunda e } & \text { pasagem é o grande limitante ao } \\ & & \text { terceira } & \text { consumo de forragem por animais } \\ & & & \text { em pastejo sobrepondo-se à } \\ & & & \text { utilização de suplementos } \\ & & \end{array}$

Sétima oitava e nona

1366

Primeira segunda e terceira
A utilização de suplementos energéticos para bovinos em pastejo, apresenta efeito mais acentuado quando a disponibilidade de matéria seca verde esteja limitando 0 consumo de energia digestivel pelos animais. pasagem é o grande limitante ao consumo de forragem por animais em pastejo sobrepondo-se à utilização de suplementos

A utilização de suplementos energéticos para bovinos em pastejo, apresenta efeito mais acentuado quando a estrutura da pastagem esteja limitando o consumo de energia digestivel pelos animais.
A disponibilidade de matéria seca da

leia-se

0,13

0,085

$-0,043$

0,03

0,22

0,61

58,34

60,74

0,2420

0,0001

0,0001

O NDT sofreu efeito do resíduo.....

54,97

62,00

63,85

57,34

0,3423

0,0001

0,0001

0,0016

0,0001

0,0002

A disponibilidade de massa seca da pastagem é o grande limitante ao consumo de forragem por animais em pastejo, enquanto a utilização de suplementos energéticos ou protéico elevou 0 consumo de matéria seca da dieta.

O efeito de substituição provocado pela suplementação foi baixo, elevando a ingestão de matéria seca total.

A disponibilidade de massa seca da pastagem é o grande limitante ao consumo de forragem por animais em pastejo, enquanto a utilização de suplementos energéticos e protéico elevou 0 consumo de matéria seca da dieta.

O efeito de substituição sexta provocado pela suplementação foi baixo, elevando a ingeståo de matéria seca total. 


\section{Dados Internacionais de Catalogação na Publicação (CIP) DIVISĀO DE BIBLIOTECA E DOCUMENTAÇĀO - ESALQ/USP}

Manzano, Ricardo Pereira

Consumo, parâmetros digestivos e comportamento de bovinos de corte em pastejo de capim Tanzânia (Panicum maximum Jacq. cv Tanzânia) suplementados com fontes de energia ou de proteína / Ricardo Pereira Manzano. - - Piracicaba, 2002.

$160 \mathrm{p}$.

Tese (doutorado) - Escola Superior de Agricultura Luiz de Queiroz, 2002.

Bibliografia.

1. Bovinos de corte 2. Capim coloniāo 3. Comportamento ingestivo animal 4. Digestão 5. Pastejo 6. Suplementos energéticos para animais. I. Título

CDD 636.2085 


\title{
À minha esposa, Ana Paula e \\ Ao meu filho, João Otávio
}

\author{
Por suportarem a minha falta e pelo incentivo, apoio, amizade \\ e carinho que sempre demonstraram.
}




\section{AGRADECIMENTOS}

À Escola Superior de Agricultura Luiz de Queiroz (USP) e em especial ao Departamento de Produção Animal - Setor de Ruminantes, pela oportunidade de realização deste curso.

Ao Prof. Dr. Luiz Gustavo Nussio pela orientação segura, pelos ensinamentos valiosos, pela amizade, confiança e exemplo de dedicação profissional.

À Fundação de Amparo à Pesquisa do Estado de São Paulo (FAPESP), pela concessão da bolsa de estudos durante o transcorrer do curso e pelo financiamento do projeto através dos recursos disponibilizados na reserva técnica da bolsa.

Ao Prof. Dr. Max Lázaro Vieira Bose, pela amizade, apoio e incentivo durante o curso de doutorado.

Ao Dr. José Manuel Corrêa de Simas, pelas sugestões, colaboração e orientação na execução deste trabalho, pela amizade e exemplo profissional.

Aos Prof. Dr. César Gonçalves de Lima e Irineu Umberto Packer pelo auxílio e sugestões preciosas na análise estatística dos dados.

Ao Prof. Dr. Alexandre Vaz Pires pela execução das cirurgias.

Ao Prof. Dr. Moacyr Corsi por ter viabilizado a área experimental para realização deste trabalho.

Ao Prof. Dr. Flávio Augusto Portela Santos pelo auxílio na formulação das dietas.

Ao Prof. Dr. Wilson Roberto Soares de Mattos pelas sugestões e participação ativa na redação final do trabalho.

Aos demais professores do Departamento de Produção Animal, pelos ensinamentos, cordialidade e pela amizade.

Aos estagiários Edson H. Soares, Karina Z. Veiga, Karlen B. Lopes, 
Marcos V. Salione, Mariana P. Andreucci, Rafael Z. M. Costa pela lealdade e dedicação fundamentais para condução do experimento no campo.

Aos amigos e colegas de curso Carla Maris de Bittar Nussio, Felipe Tonato, Francisco Nogueira Dias, Hugo Imaizume Juliano José de Resende Fernandes, Liliane Suguisawa e Rodrigo Michelini Coelho pela amizade e pelo auxílio na condução das análises laboratoriais.

Ao amigo Dr. Fábio Prudêncio de Campos pelas sugestões e auxílio na correção do trabalho escrito.

Ao funcionário do Laboratório de Bromatologia do Departamento de Produção Animal Carlos César Alves, pela amizade, paciência e ensinamentos durante as análises laboratoriais.

Aos demais funcionários e colegas do curso de pós-graduação, pela amizade, pela ajuda e pela agradável convivência.

Aos meus queridos pais José Roberto e Edith e minhas irmãs Roberta e Rejane, pela confiança e grande incentivo para execução deste trabalho.

Às pessoas que, direta ou indiretamente, contribuíram para a realização deste trabalho. 


\section{SUMÁRIO}

Página

RESUMO

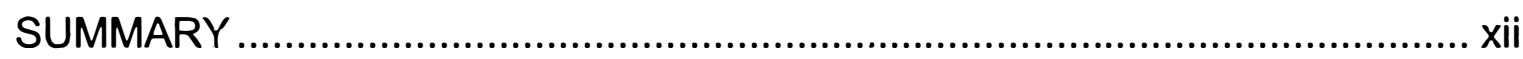

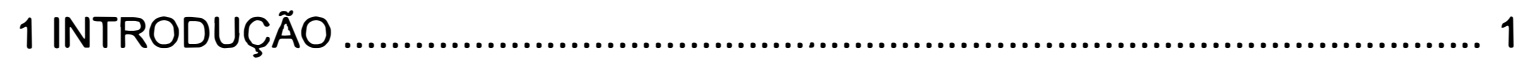

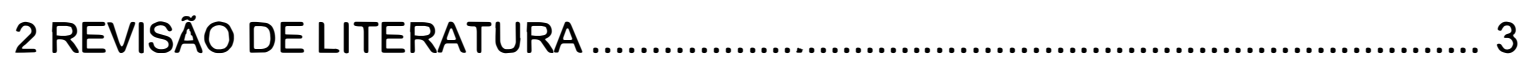

2.1 Caracterização das plantas forrageiras tropicais no período das águas ...... 3

2.2 Ingestão de forragem durante o pastejo pelos animais .................................. 4

2.3 Suplementação de bovinos de corte mantidos em pastagens no verão....... 9

2.4 Parâmetros ruminais ............................................................................. 13

2.4.1 Concentração de nitrogênio amoniacal no fluido ruminal ......................... 13

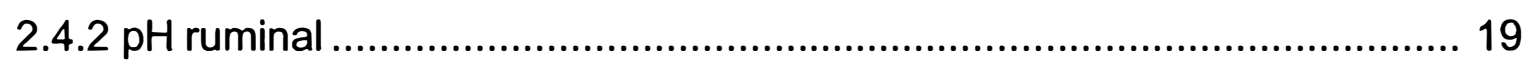

2.4.3 Perfil da concentração de ácidos graxos voláteis...................................... 24

2.4.4 Degradação ruminal da matéria seca e da fibra....................................... 31

2.5 Comportamento de pastejo ...................................................................... 36

3 CONSUMO, PARÂMETROS RUMINAIS E DIGESTIBILIDADE DE NUTRIENTES EM DE BOVINOS DE CORTE MANEJADOS SOB PASTEJO ROTACIONADO EM CAPIM TANZÂNIA (Panicum maximum Jacq. cv. Tanzânia) E SUPLEMENTADOS COM 
Resumo

Summary 43

3.1 Introdução 44

3.2 Material e métodos 48

3.2.1 Instalações experimentais e animais 48

3.2.2 Tratamentos 49

3.2.3 Período experimental 50

3.2.4 Consumo de matéria seca da pastagem 51

3.2.5 Coleta de conteúdo ruminal e determinação do $\mathrm{pH}$, ácidos graxos voláteis e nitrogênio amoniacal.

3.2.6 Coleta de amostras dos alimentos e análises bromatológicas nos alimentos e nas fezes 53

3.2.7 Determinação da digestibilidade verdadeira da matéria orgânica e da digestibilidade aparente dos nutrientes.

3.2.8 Ensaio de degradabilidade "in situ" da matéria seca para determinação do consumo de matéria seca da pastagem.

3.2.9 Análise estatística. 60

3.3 Resultados e discussão. 62

3.3.1 Consumo de matéria seca, matéria orgânica e fibra detergente neutro.

3.3.2 Parâmetros ruminais 74

3.3.3 Digestibilidade aparente 85

3.4 Conclusões. 93 
4 COMPORTAMENTO INGESTIVO E SUA RELAÇÃO COM A ESTRUTURA DA PASTAGEM CONSUMIDA POR BOVINOS DE CORTE SUPLEMENTADOS COM PROTEÍNA OU ENERGIA EM PASTEJO ROTACIONADO.

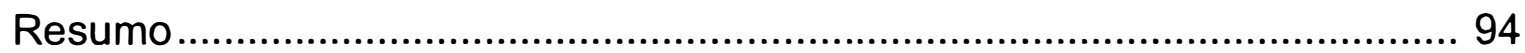

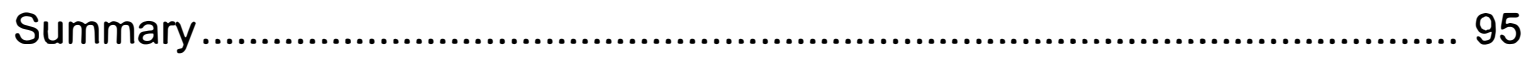

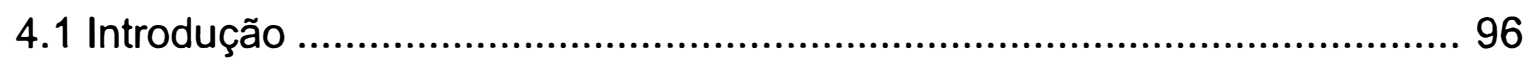

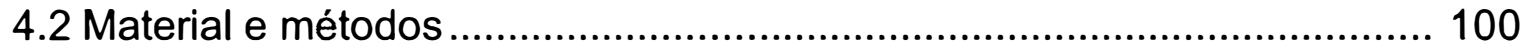

4.2.1 Instalações experimentais e animais.............................................. 100

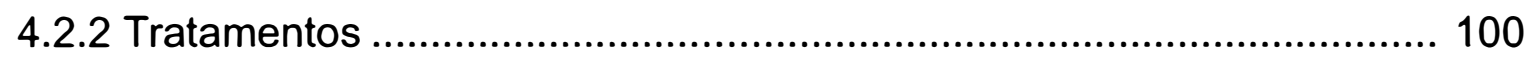

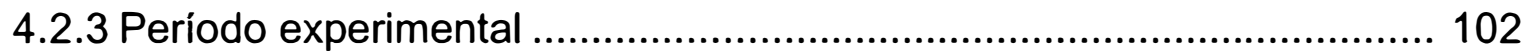

4.2.4 Avaliação do comportamento de pastejo e da estrutura do dossel ...... 102

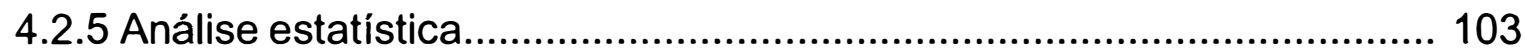

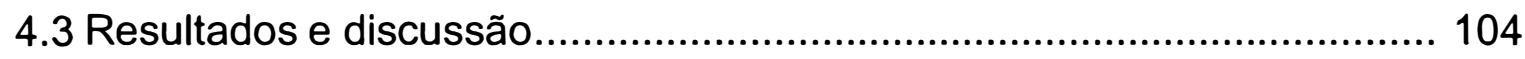

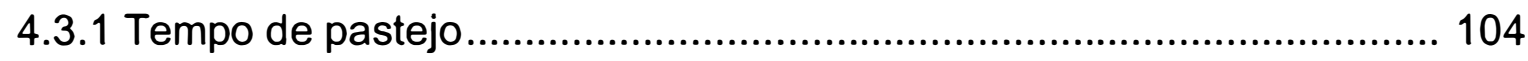

4.3.2 Tempo de ruminação e tempo em ócio .............................................. 111

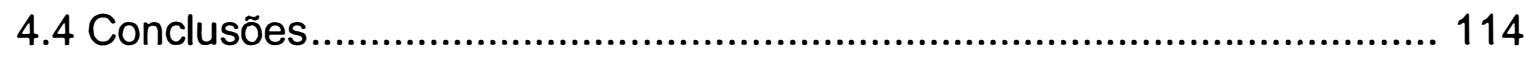

5 EFEITO DA SUPLEMENTAÇÃO ENERGÉTICA OU PROTÉICA SOBRE A DEGRADABILIDADE RUMINAL DO CAPIM TANZÂNIA (Panicum maximum Jacq. cv. Tanzânia) MANEJADO SOB DOIS RESÍDUOS PÓS PASTEJO, EM SISTEMA ROTACIONADO DE PASTEJO, NO VERÃO......................................................... 115

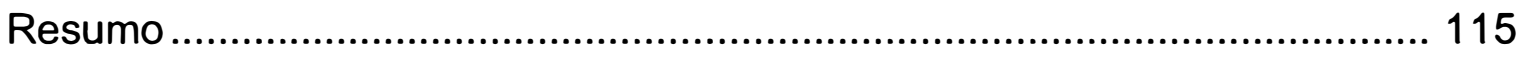

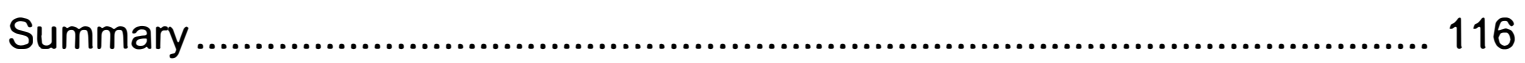

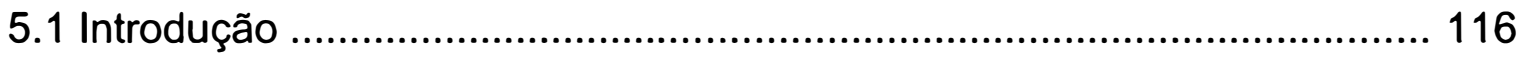


5.2 Material e métodos

5.2.1 Instalações experimentais e animais 121

5.2.2 Tratamentos 122

5.2.3 Período experimental 123

5.2.4 Degradabilidade "in situ". 124

5.2.5 Análise estatística 126

5.3 Resultados e discussão. 127

5.4 Conclusões. 135

6 CONCLUSÕES GERAIS 136

REFERÊNCIAS BIBLIOGRÁFICAS 137 


\title{
CONSUMO, PARÂMETROS DIGESTIVOS E COMPORTAMENTO DE BOVINOS DE CORTE EM PASTEJO DE CAPIM TANZÂNIA (Panicum maximum Jacq. cv. Tanzânia) SUPLEMENTADOS COM FONTES DE ENERGIA OU DE PROTEÍNA
}

\author{
Autor: RICARDO PEREIRA MANZANO \\ Orientador: Prof.LUIZ GUSTAVO NUSSIO
}

\section{RESUMO}

O objetivo foi de avaliar o efeito da suplementação energética ou protéica sobre o comportamento ingestivo e os parâmetros digestivos, de bovinos sob pastejo, com duas disponibilidades de forragem diferentes no verão. Oito garrotes da raça Nelore foram utilizados em um sistema de pastejo rotacionado, em capim Tanzânia, sob dois níveis de resíduo de MS verde (MSV), obtidos após a saída dos animais $\left(R 1=1000 \mathrm{~kg} \mathrm{ha}^{-1}\right.$ de MSV e R2 $=4000 \mathrm{~kg} \mathrm{ha}^{-1}$ de MSV). Quatro garrotes foram alocados a cada um dos resíduos, sendo distribuídos em dois quadrados latinos $4 \times 4$, onde cada animal recebeu um tratamento de suplementação ( $S 0=$ sem suplementação; $S 1=2,24 \mathrm{~kg} \mathrm{dia}^{-1}$ de milho moído grosso; $\mathrm{S} 2=2,24 \mathrm{~kg} \mathrm{dia}^{-1}$ de milho floculado; $\mathrm{S} 3=0,7 \mathrm{~kg} \mathrm{dia}^{-1} \mathrm{de}$ farelo de soja). Os ciclos de pastejo se constituiram em 33 dias como período de descanso e 3 dias de ocupação. Houve aumento do tempo de pastejo (470,63 contra 354,28 minutos dia $\left.^{-1}\right)$, tempo de ruminação $(408,48$ contra 319,06 minutos dia $\left.^{-1}\right)$ e do consumo de matéria seca da forragem $(P<0,05)$ 
com o aumento na disponibilidade de MSV. O tempo em ócio foi elevado com a redução na disponibilidade de matéria seca $(P<0,05)$. Houve aumento de consumo de matéria seca total e de matéria orgânica total, com a suplementação $(P<0,05)$. A suplementação reduziu o tempo de ruminação, o pH ruminal, a relação acético:propiônico e elevou a concentração molar de ácido propiônico no fluido rumimal $(P<0,05)$. Animais manejados no menor resíduo de MSV pós pastejo, apresentaram maior concentração total de ácidos graxos voláteis $(P<0,05)$. Não foram observados efeitos significativos da disponibilidade de forragem sobre a digestibilidade dos nutrientes $(P>0,05)$, à exceção da PB. O uso de milho moído grosso elevou a digestibilidade da porção fibra, enquanto que o milho floculado, estimulou a digestibilidade do amido $(P<0,05)$. A suplementação e a disponibilidade de forragem não alteraram o NDT e os parâmetros de degradabilidade ruminal da matéria seca $(P>0,05)$. Os parâmetros de degradabilidade das frações FDN e FDA não foram alterados pela suplementação $(P>0,05)$. O resíduo de matéria seca verde pós pastejo influenciou a fração insolúvel e potencialmente degradável da FDN e FDA, que foram superiores para o R1 ( $P<0,05)$; e a taxa fracional de degradação da FDN que foi inferior para o R1 $(P<0,05)$. A degradabilidade potencial da FDA foi superior para o R1 $(P<0,05)$. A disponibilidade de forragem, vinculada ao maior resíduo pós pastejo, exerceu influência mais acentuada do que a suplementação sobre os parâmetros avaliados. 


\title{
INTAKE, DIGESTIVE PARAMETERS AND BEHAVIOR OF BEEF STEERS ON TANZANIA GRASS (Panicum maximum Jacq. cv. Tanzania) PASTURE, SUPPLEMENTED WITH ENERGY OR PROTEIN SOURCES.
}

\author{
Author: RICARDO PEREIRA MANZANO \\ Adviser: Prof. LUIZ GUSTAVO NUSSIO
}

\section{SUMMARY}

The aim of this study was to evaluate the effect of energy or protein supplementation on the feeding behavior and digestive parameters of grazing steers, under two forage allowances in the summer. Eight Nelore steers on a rotational system in Tanzania pasture were utilized, under two levels of green dry matter $(G D M)$ residues, obtained after the animals withdrawal $(R 1=1,000$ and R2 $\left.=4,000 \mathrm{~kg} \mathrm{day}^{-1} \mathrm{GDM}\right)$. Four animals were placed on each one of the post grazing residue. Four sources of supplements (WO - no supplement; CC$2.24 \mathrm{~kg} \mathrm{day}^{-1}$ cracked corn; SFC - $2.24 \mathrm{~kg} \mathrm{day}^{-1}$ steam flaked corn; and SBM $0.7 \mathrm{~kg}^{\text {.day }}{ }^{-1}$ soybean meal) were used in a Latin square design. Grazing cycles presented 33 days of rest and 3 days of grazing. There was an increase on grazing and ruminating times (470.63 vs. 354.28 and 408.48 vs. 319.06 minutes day $^{-1}$, respectively), as well as on forage dry matter intake $(P<.05)$ along with increase on GDM allowances. Time spent resting was increased when reducing dry matter allowance $(P<.05)$. Higher total dry and organic matter intakes were observed for animals receiving supplementation $(P<.05)$. Supplementation 
reduced rumination time, ruminal $\mathrm{pH}$, acetic:propionic ratio, and increased molar concentration of propionic acid in ruminal fluid $(P<.05)$. Animals managed under lower GDM post grazing residue presented higher VFA total concentration $(P<.05)$. Forage allowance resulted in no significant effects on nutrients digestibility $(P>.05)$, excepting $C P$. Cracked corn increased fiber digestibility, while steam flaked corn stimulated starch digestibility $(P<0.05)$. Supplementation and forage allowance did not alter TDN and parameters of dry matter ruminal degradability $(P>.05)$.. Degradability parameters of ADF and NDF fractions were not altered by supplementation ( $P$ > .05). GDM post grazing residue influenced insoluble and potentially degradable fractions of ADF and NDF, which were superior for R1 $(P<.05)$; and the fractional rate of NDF degradation was lower for $R 1(P<.05)$. ADF potential degradability was higher for R1 $(P<0.05)$. Forage allowance, linked to higher post-grazing residue, exerted stronger influence than supplementation on the evaluated parameters. 


\section{INTRODUÇÃO}

A produção de bovinos de corte em países tropicais pode atingir niveis satisfatórios de produtividade devido ao elevado potencial de produção de matéria seca das pastagens. As plantas forrageiras, em geral, são as responsáveis pela oferta de energia, proteína, vitaminas e parte dos elementos minerais necessários ao atendimento das exigências de manutenção e produção dos animais. No entanto, o desempenho de bovinos em pastejo ainda está aquém de seu potencial produtivo, devido às características nutricionais que as plantas forrageiras impõem: elevados teores de fibra, baixos teores de carboidratos não estruturais e grande proporção de nitrogênio sob a forma solúvel e vinculado à parede celular, em pastagens manejadas intensivamente com utilização de altas doses de adubos nitrogenados.

O excesso de nitrogênio solúvel aliado ao déficit de carboidratos não estruturais (CNE) encontrados na matéria seca dessas gramíneas conduzem ao excesso de amônia no fluido ruminal. A suplementação com concentrados, visando suprir as necessidades energéticas do animal, poderá otimizar os processos fermentativos no rúmen, fornecendo fontes de carboidratos rapidamente fermentáveis, que juntamente com $\circ$ nitrogênio amoniacal, presente no ambiente ruminal aumenta a eficiência da síntese de proteína microbiana, fato que influenciará a cinética da degradação da parede celular das plantas forrageiras. Entretanto, a utilização desses suplementos, principalmente os energéticos, poderá alterar o comportamento de pastejo, além de provocar o efeito substitutivo, que limita a ingestão de matéria seca forragem, principalmente quando esta apresentar alto valor nutritivo. 
Nas duas últimas décadas houve a tendência generalizada, entre nutricionistas, em difundir o conceito de se suplementar animais de alta produção, com alimentos ricos em proteinas que ultrapassem o ambiente ruminal, sendo digeridas no intestino. Esse processo teoricamente promoveria 0 aumento no fluxo de aminoácidos para o intestino delgado de ruminantes consumindo dietas completas. Esse conceito foi desenvolvido a partir de hipóteses, cálculos teóricos e ensaios de infusão intestinal de caseína e expresso pelo termo "by pass". No entanto, a utilização de bovinos fistulados em ensaios metabólicos e de produção, vem gerando resultados conflitantes aos obtidos anteriormente. O fornecimento de aminoácidos para ruminantes consumindo dietas pobres em proteína de baixa degradabilidade ruminal, poderia ser estimulado através do aumento na síntese de proteína microbiana, que possui um perfil de aminoácidos de alto valor biológico quando comparado a valores apresentados na carcaça de animais de corte.

Em contrapartida, resultados de trabalhos com animais pastejando gramíneas tropicais, manejadas sob altas lotações, durante o período de verão, recebendo suplementação concentrada, são escassos.

Assim, o objetivo do trabalho foi o de avaliar o efeito da suplementação energética, sobre o comportamento dos animais em pastejo, sobre os parâmetros ruminais e a de digestão das porções fibrosas e de amido da dieta de bovinos de corte em recria, alocados em pastagens manejadas intensivamente, durante o período do verão. 


\section{REVISÃO DE LITERATURA}

\subsection{Caracterização das plantas forrageiras tropicais no período das águas}

As plantas forrageiras tropicais apresentam alta produtividade, em função dessas apresentarem um sistema enzimático eficiente na incorporação de carbono $\left(\mathrm{C}_{4}\right)$, o qual confere maior eficiência no uso de água e nutrientes minerais para o crescimento e consequente acúmulo de matéria seca. Entretanto, essas plantas demonstram elevado conteúdo de parede celular e apresentam menores valores de digestibilidade, e consequentemente menores consumos por animais ruminantes (Humphreys, 1991). Isso ocorrê porque as forragens tropicais apresentam niveis de fibra em detergente neutro (FDN) ao redor de $65 \%$ a $75 \%$ da matéria seca (Van Soest, 1994; Cowan \& Lowe, 1998; Nussio et al. 1998).

No verão, período de crescimento das pastagens, o conteúdo protéico das dessas plantas apresenta níveis acima de 6 a $8 \%$, o que garante a fermentação adequada no rúmen (Minson, 1990), não constituindo assim, em barreira ao consumo de forragem, a deficiência de nitrogênio. Nessa época, o consumo é limitado pelo alto conteúdo de parede celular presente na matéria seca forragem (Mertens, 1994), desde que a disponibilidade de forragem e a estrutura do pasto não limitem a apreensão pelo animal (Poppi et al., 1987).

Segundo Hogan (1982) quando o suprimento de proteína bruta pela forragem encontra-se acima de $7 \%$, a degradabilidade ruminal afeta a quantidade de nitrogênio protéico direcionada ao intestino delgado dos ruminantes, para ser utilizado como fonte de aminoácidos essenciais e/ou como 
fonte de energia. Esse autor relata também, que forragens produzidas nesse periodo, possuem $80 \%$ de seu conteúdo nitrogenado na forma de proteína de alta solubilidade ruminal, o que aumenta as chances de degradação dessa proteína no rúmen. Esse fato, aliado ao alto conteúdo de carboidratos estruturais, com menores taxas de degradação, provoca a falta de sincronia entre nitrogênio e esqueletos carbônicos oriundos da degradação de carboidratos, desfavorecendo a sintese de proteina microbiana. Poppi e McLennan (1995) relataram que isso é comum não só para forragens tropicais, mas também para forragens de clima temperado, que possuem maior conteúdo de carboidratos não estruturais.

Quando pastagens tropicais são adubadas com nitrogênio, o problema acentua-se (Boin et al., 1997), pois ocorre um aumento na concentração de nitrogênio na matéria seca das plantas adubadas, sem elevação concomitante no teor de corboidratos não estruturais. Além disso, adubações nitrogenadas promovem maior crescimento da planta forrageira obrigando a mesma a aumentar a síntese de parede celular (Minson, 1990). Essa situação será responsável pela baixa produção de proteina microbiana e pela redução na eficiência de uso do nitrogênio presente na forragem, pelos animais em pastejo. Deve-se considerar ainda, que energia adicional será necessária para metabolizar e excretar o nitrogênio amoniacal absorvido do rúmen (Poppi \& McLennan, 1995). Desta forma o ganho de peso individual de bovinos em pastagens tropicais, tem sido limitados a níveis próximos de $0,7 \mathrm{~kg}^{\mathrm{d}} \mathrm{dia}^{-1}$ (Humphreys, 1991).

\subsection{Ingestão de forragem durante o pastejo pelos animais}

A ingestão de forragem através de pastejo, é controlada por fatores como o animal, a forragem e o ambiente (Mertens, 1994). A maioria desses fatores, aplicam-se a animais estabulados, mas alguns são exclusivos para animais em pastejo. Para esses animais, inclui-se a oportunidade de pastejar seletivamente 
e influenciar a ingestão de forragem disponivel no ato de colheita (bocado). Alguns estudos têm sido propostos, para confirmar sob condições de pastejo, princípios já estabelecidos com animais estabulados, recebendo forragem cortada, mas em outros estudos o foco é direcionado ao entendimento dos fenômenos nas condições de pastejo (Minson, 1990).

A importância da ingestão de forragem como um fator determinante da produtividade animal está claramente estabelecida. Entretanto, o processo pelo qual os ruminantes suprem suas necessidades ainda encontra-se por esclarecer (Cosgrove, 1997). No entanto, é importante ressaltar que a ingestão de forragem está positivamente ligada ao valor nutritivo da forragem, através da taxa de redução do tamanho de partícula no rúmen e da taxa de passagem pelo rúmen (Minson, 1990), bem como a pela taxa de degradação ruminal da matéria seca (Van Soest, 1994).

Conrad et al. (1964) e Mertens (1994), estabeleceram que o consumo de matéria seca por um animal é limitado por processos físicos e ou fisiológicos. 0 limite físico significa a capacidade do rúmen suportar a quantidade de alimento ingerido. Esse fator exerce maior importância quando a dieta, caracterizada por maior proporção de volumoso, apresenta digestibilidade entre 52 e 66,7\%, enquanto que o limite fisiológico passa a ter importância em dietas com digestibilidade da matéria seca acima de $66,7 \%$. Nesse caso, o término da refeição é caracterizado por fatores quimiostáticos, isto é, a elevação da concentração de produtos metabólicos no rúmen (acido acético), ou no sangue (ácido propiônico), que estimulariam receptores quimicamente sensíveis. Esses receptores são capazes de transmitir impulsos para o centro da saciedade no sistema nervoso central, encarregado de regular o consumo pelo animal (Thiago \& Gill, 1990; Forbes, 1995).

O sistema de consumo de fibra relacionado com energia, foi desenvolvido por Mertens \& Ely (1982) e Mertens (1987), que explicam que o consumo de matéria seca pelos animais dependeria da quantidade de fibra ingerida, expressa em FDN, o qual procura associar a energia da dieta com o 
enchimento do trato digestivo. Avaliações preliminares sugeriram, que o limite máximo de ingestão de matéria seca por novilhos de corte é atingido quando esses animais consomem $12,5 \mathrm{~g}$ de FDN kg de peso vivo ${ }^{-1}$, quando a forragem apresentar teores de FDN dentro da amplitude de $25 \%$ a $70 \%$ da matéria seca (Mertens, 1994).

Esse consumo permitiria a maximização da ingestão de energia, o qual promovera um elevado desempenho animal. No entanto, consumos de FDN inferiores a estes são aceitáveis, desde que sejam acompanhados por aumento na densidade energética da dieta, para que o animal possa manter o mesmo desempenho (Mertens, 1992).

A concentração de proteína na dieta também pode ser um fator limitante ao consumo de matéria, pois poderia provocar um déficit de nitrogênio aos microrganismos ruminais, deprimindo a degradação da parede celular de forragens, atrasando o esvaziamento do conteúdo ruminal (Leng, 1990). Entretanto, o déficit de proteína bruta, em pastagens adubadas, durante a estação de crescimento, não seria fator limitante ao consumo.

Em recente revisão Caton \& Dhuyvetter (1997) observaram que a ingestão de matéria seca por bovinos em pastejo variou entre 0,91 a 4,3\% do peso vivo, em animais que pastejaram campos nativos ao longo do ano. Esses autores sugerem que a ingestão de forragem por bovinos em pastejo é muito variável e mal definida. Funk et al (1987) obtiveram resultados de consumo médio de matéria orgânica de $2,6 \%$ do peso vivo com novilhos pastejando "Blue grama" (Bouteloua gracilis) na estação de crescimento do capim.

No Brasil, Thiago et al. (1991), averiguaram a ingestão de matéria seca de novilhos de corte estabulados, fornecendo quatro gramíneas tropicais fenadas, com 130 dias de crescimento. Observaram consumos voluntários de matéria seca de $1,82 \%, 1,98 \%$ e $1,96 \%$ e $2,11 \%$ do peso vivo do animal para a Brachiaria decumbens, e os capins Colonião, Tobiatã e Tanzânia, respectivamente.

Balsalobre (1996) trabalhou com vacas de leiteiras em lactação 
pastejando Capim-elefante suplementadas com concentrados, e observou consumo médio de matéria seca da forragem de $11,31 \mathrm{~kg} \mathrm{vaca}^{-1} \mathrm{dia}^{-1}$, equivalendo ao consumo de $2,12 \%$ do peso vivo dos animais. $O$ consumo de concentrado foi variável em função do nível de produção e do estágio de lactação de cada animal.

Aroeira et al. (1996) trabalharam com vacas de leiteiras pastejando Capim-elefante com 30, 37,5 e 45 dias de descanso, suplementadas com $2 \mathrm{~kg}$ de concentrado por dia, e 30 dias de descanso, sem suplementação concentrada. As ingestões de MS provenientes do pasto no período do verão foram de $2,86 \%$ do peso vivo, para os animais que não receberam suplementação (30 dias de descanso). Registrou-se ingestões de MS equivalentes a 2,80; 2,89 e 2,60\% do peso vivo, para as vacas suplementadas e alocadas aos piquetes com 30; 37,5 e 45 dias de descanso, respectivamente.

Ribeiro et al. (1997) trabalharam com novilhos de corte pastejando Capim-elefante anão cv. "MOTT" com 4 ofertas de forragem $(4,8,12$ e $16 \mathrm{~kg}$ de

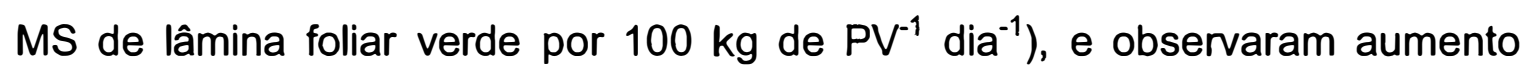
linear no consumo de matéria orgânica $(\mathrm{MO})$ da pastagem, quando se elevou a disponibilidade de forragem para os animais. Os valores atingidos para o consumo de $\mathrm{MO}$ variaram entre 2,5 e $3,7 \%$ do peso vivo. Nesse experimento, a resposta linear obtida, em função da oferta de forragem, foi caracterizada pelo incremento no consumo de $\mathrm{MO}$, da ordem de $0,18 \%$ do peso vivo do animal por $\mathrm{kg}$ de acréscimo na matéria seca de lâmina foliar ofertada para cada $100 \mathrm{~kg}$ de peso vivo dia ${ }^{-1}$. É importante ressaltar que até atingir a oferta de forragem de $13 \%$, esses autores constataram que o consumo aumentou linearmente. $A$ partir desse ponto, observaram diminuição do consumo de MO. A ingestão de forragem e o desempenho do animal aumentaram a uma taxa decrescente, com o aumento da disponibilidade de forragem. O consumo atinge o valor máximo quando a disponibilidade de MS for iqual a $10-12 \%$ do peso vivo do animal, na maioria dos sistemas de pastejo (Hodgson 1990).

O uso de suplementos tem efeito marcante sobre o consumo de matéria 
seca da pastagem. Segundo Paterson et al. (1994) o uso de suplementos protéicos, para animais ingerindo forragens com niveis de proteína bruta inferiores a $7 \%$, eleva a ingestão de matéria seca dessa forragem. Em contrapartida, esses autores observaram que o uso de suplementos energéticos provocam redução na ingestão de forragem, sendo acentuada à medida que a qualidade ou a disponibilidade da forragem for maior (Minson, 1990; Paterson et al. 1994; Dixon \& Stockdale, 1999).

Dixon \& Stockdale (1999) em extensa revisão, observaram que o consumo voluntário de forragem é mais importante que a digestibilidade na determinação do efeito de substituição.

O coeficiente de substituição médio obtido por Minson (1990) e Paterson et al. (1994), para pastagens e alimentos volumosos fornecidos para animais estabulados, foi de 0,69, com uma amplitude de variação entre 0,25 e 1,67. Boin et al. (1997) relataram que as taxas de substituição variam entre 1,00 e 0,65 para forragens de alto e baixo ( $50 \%$ de digestibilidade) valor nutritivo, respectivamente. Galloway et al. (1993) observaram taxas de substituição variando entre 0,41 a 0,68 para bovinos recebendo feno de Bermuda Greenfield (Cynodon dactylon) ad libitum, com 9,7\% de PB, 71,5\% de FDN, e $51 \%$ de digestibilidade aparente da matéria orgânica; suplementado com milho inteiro, milho moído, sorgo inteiro ou trigo inteiro em niveis de $1 \%$ do peso vivo. Combs (1997) afirmou que para vacas leiteiras em lactação, em condições de pastejo em pastagens temperadas, o coeficiente de substituição foi de 0,4 a 0,6, quando adicionou-se grãos à dieta dos animais.

Outra fator a ser considerado é que o coeficiente de substituição pode ser alterado em função da quantidade de suplemento energético fornecido aos animais (Hodgson, 1990; Caton \& Dhuyvetter, 1997). Muitas vezes, pequenas quantidades de suplementos, compostos por fontes de carboidratos rapidamente solúveis e fontes de nitrogênio, podem em alguns casos elevar a ingestão de forragens (Hodgson, 1990). Henning et al. (1980) ao suplementarem ovinos consumindo palha de milho com grãos de milho, 
observaram que os baixos niveis de suplementação determinaram aumento do consumo de volumoso. Entretanto, níveis maiores de suplementação provocaram depressão no consumo do volumoso, quando comparado a animais que não foram suplementados. Matejovsky \& Sanson (1995) também observaram que baixos níveis de suplementação energética, para ovinos, elevaram o consumo das dietas a base de forragens. Contudo, relatos da suplementação energética aumentando a ingestão de forragem, ocorrem mais freqüentemente em estudos com ovinos, que com bovinos (Caton \& Dhuyvetter, 1997). Segundo Opatpatanakit et al. (1995) há evidências de que carboidratos rapidamente fermentáveis no rúmen, fornecidos de forma suplementar, em quantidades de $0,1 \%$ do peso vivo do animal, apresentariam efeito associativo positivo. Isto é, não só evitariam o efeito de substituição, bem como promoveriam aumento na ingestão de matéria seca da forragem por animais suplementados.

\subsection{Suplementação de bovinos de corte mantidos em pastagens no verão}

O uso de suplementos energéticos durante o período do verão tem apresentado resultados positivos, elevando o ganho de peso dos animais, comparado ao consumo exclusivo de pastagem, tanto para gramíneas temperadas (Perry et al. 1972; Kemalyan et al. 1991; Hess et al. 1996) quanto para gramineas tropicais (Bodine et al. 2001; Prohmann et al. 2001; Cruz et al. 2001).

Entretanto, o ganho de peso adicional é dependente da quantidade de suplemento oferecido (Coutinho Filho et al. 2001). Prohmann et al. (2001) observaram efeito linear sobre o ganho de peso de novilhos, com $360 \mathrm{~kg}$ de peso vivo, recriados em pastagens de coast-cross (Cynodon dactylon) e suplementados com casca de soja. Esses autores ofertaram 0; 0,2; 0,4 e 0,6\% do peso vivo dos animais, em casca de soja, e observaram ganhos de peso diários de 0,859; 0,853; 0,949 e 0,988 kg, respectivamente. 
$\mathrm{O}$ uso de $3 \mathrm{~kg}$ de concentrado, composto por milho, farelo de trigo e farelo de soja (18\% PB e $81,5 \%$ de NDT) elevou em $0,48 \mathrm{~kg} \mathrm{dia}^{-1}$ o desempenho de machos inteiros em pastagens adubadas sob manejo rotacionado (Cruz et al. 2001), enquanto que, o consumo de $298 \mathrm{~g}$ de um mistura energética à base de milho $(56,63 \%$ da MS) propiciou o incremento de $0,063 \mathrm{~kg} \mathrm{cab}^{-1} \mathrm{dia}^{-1} \mathrm{em}$ pastagens manejadas sob lotação contínua nas águas (Coutinho Filho et al. 2001).

A suplementação protéica de animais em pastejo, no verão, também tem propiciado desempenhos superiores dos animais suplementados em relação aos não suplementados, tanto para proteína de alta degradabilidade ruminal, como o farelo de algodão (Worrel et al. 1990), quanto para o uso de suplementos com fontes de baixa degradabilidade ruminal (Anderson et al. 1988, Karges et al. 1992; Hafley et al. 1993). Marcondes et al. (2001) utilizaram suplementos contendo proteína degradável no rúmen, suplementos com proteína não degradável no rúmen e milho como suplemento energético, e observaram que tanto a proteína não degradável no rúmen quanto a proteína degradável elevaram o desempenho de bezerros zebuínos desmamados e recriados em pastagens de Brachiaria decumbens no verão, quando comparados ao controle. Entretanto, não ocorreu diferença estatística entre as formas de proteína utilizadas na suplementação.

Outro experimento foi realizado comparando o desempenho de bovinos não suplementados em relação à suplementação com milho, proteína não degradável no rúmen (farelo de soja tratado) e proteína degradável no rúmen (farelo de soja) (Fairbrother \& Brink, 1991). Esses autores utilizaram novilhos com $246 \mathrm{~kg}$ de peso vivo, pastejando Tifton 44 (Cynodon dactylon) e bermuda comum (Cynodon dactylon), adubadas com $180 \mathrm{~kg}$ de $\mathrm{N} \mathrm{ha}{ }^{-1} \mathrm{e}$ apresentando $9,2 \%$ de PB, $77 \%$ de FDN na MS e $41,6 \%$ de DIVMS. Constataram que apenas o tratamento com proteína de baixa degradabilidade ruminal apresentou efeito estatisticamente significativo $(p<0,05)$ sobre o ganho de peso diário. Os ganhos de peso vivo diário obtidos foram de 0,$67 ; 0,70 ; 0,81$ e $0,77 \mathrm{~kg}$ para os 
tratamentos sem suplemento, milho, farelo de soja tratado (baixa degradabilidade ruminal) e farelo de soja (alta degradabilidade ruminal), respectivamente.

O ganho de peso depende principalmente do suprimento de aminoácidos e dos nutrientes supridores de energia aos tecidos, para a síntese protéica sob limite genético, a qual provavelmente não é atinginda por animais consumindo pastagens (Poppi \& McLennan, 1995). A adição de suplementos energéticos à dieta de animais pastejando gramíneas no verão, elevaria a disponibilidade de matéria orgânica fermentável no rúmen, favorecendo assim, a síntese de proteína microbiana (Pordomingo et al. 1991), além de aumentar a disponibilidade dos precursores glucogênicos para o metabolismo animal (Dixon \& Stockdale 1999), desde que o efeito de substituição não fosse equivalente ou maior que 1,0 (Pordomingo et al. 1991).

Segundo Noller (1997) a pastagem tropical sob manejo inadeuando impõe as seguintes limitações aos animais: a) insuficiência no suprimento de forragem, b) forragem de baixo valor nutritivo e baixa digestibilidade da matéria orgânica, associada à lignificação e a elevada relação haste:folha, c) baixa concentração de proteína e com deficiência de proteína degradável no rúmen, além de baixos teores de aminoácidos disponíveis para a absorção intestinal e d) deficiências minerais, tais como fósforo, sódio, enxôfre e cobalto e algumas vezes deficiência de cobre, iodo e zinco, os quais estão relacionados com ingestão de alimentos, saúde e produção animal. Entretanto, atualmente no processo de intensificação do uso de pastagens, vem sendo acompanhado pelo uso de grandes doses de fertilizantes nitrogenados e potássicos (Corsi \& Martha Júnior, 1997). No primeiro caso, o teor de proteína e principalmente a proporção de nitrogênio não proteico aumenta, e como o teor de carboidratos não estruturais de forragens tropicais é reduzido, pode ocorrer excesso de amônia em relação à energia disponível aos microrganismos, para a síntese de proteína microbiana no rúmen, aumentando assim, a excreção de nitrogênio na urina dos animais, provocando deficiências de aminoácidos essenciais em nível 
celular. Além disso, ocorre um gasto extra de energia para metabolização do nitrogênio amoniacal absorvido do rúmen no ciclo da uréia (Boin et al., 1997; Noller, 1997), realizado no tecido hepático.

Segundo Poppi \& McLennan (1985) os ruminantes sempre respondem a suplementação de proteína de baixa degradabilidade, porém de alta disponibilidade de aminoacidos limitantes, durante a estação úmida do ano, período em que o valor nutritivo da pastagem, em termos de digestibilidade e conteúdo de proteína é elevado. Outra opção indicada por esses autores seria a suplementação desses animais, com fontes de energia para captar o excesso de amônia ruminal, e com isso aumentar a síntese de proteína microbiana. Jones et al. (1988) observaram que pequenas quantidades de grãos (0,5\% PV), fornecidas a animais em crescimento, consumindo dietas a base de feno de gramíneas tropicais, elevou o fluxo de nitrogênio microbiano para o intestino delgado, o que poderia melhorar o desempenho dos animais.

A suplementação energética, além de fornecer energia para os microrganismos ruminais, também seria útil no fornecimento de nutrientes supridores de energia ao metabolismo animal. No caso de ruminantes mantidos em pastagens, a quantidade de energia exigida pelo tecido muscular pode ser relativamente elevada, dependendo do trabalho necessário para o consumo e mastigação da forragem (Caton \& Dhuyvetter, 1997). No entanto, é importante considerar o tipo de suplemento energético fornecido, para que a energia e a amônia estejam disponiveis aos microrganismos ruminais, simultaneamente (Orskov, 1988; Noller, 1997). 


\subsection{Parâmetros ruminais}

\subsubsection{Concentração de nitrogênio amoniacal no fluido ruminal}

Segundo Satter \& Slyter (1974) níveis de nitrogênio amoniacal ruminal entre 2 e $5 \mathrm{mg} \mathrm{dL}^{-1}$ não restringem a digestão da matéria orgânica da dieta. Leng (1990) definiu que para condições tropicais, o nível mínimo de concentração de nitrogênio amoniacal no fluido ruminal seria de $10 \mathrm{mg} \mathrm{dL}^{-1}$.

Chase Junior \& Hibberd (1987) observaram valores muito próximos e abaixo do mínimo exigido por Satter \& Slyter (1974), trabalhando com animais recebendo forragem com $4,2 \%$ de $\mathrm{PB}$. $O$ valor apresentado pelos animais do tratamento controle (sem suplemento) foi de $2,2 \mathrm{mg} \mathrm{dL}^{-1}$, enquanto que a inclusão de 1; 2; e $3 \mathrm{~kg}$ de milho à dieta como suplemento energético, provocou a redução na concentração de amônia para 1,12;0,88; e $0,61 \mathrm{mg} \mathrm{dL}{ }^{-1}$, respectivamente (Chase Junior \& Hibberd 1987). Nesse experimento os picos de nitrogênio amoniacal ocorreram 3 horas após a alimentação dos animais. Bodine et al. (2001) avaliaram o efeito de suplementos a base de grãos e de fibra de alta digestibilidade (casca de soja + farelo de trigo), sobre a concentração de nitrogênio amoniacal no fluido ruminal de animais recebendo feno com 5,2\% de PB. Em geral, os níveis de nitrogênio amoniacal estiveram baixos, e os autores não encontraram efeito do tipo de suplemento, embora a suplementação tenha elevado a concentração de nitrogênio amoniacal no rúmen.

Sanson et al. (1990) avaliaram dois níveis de fornecimento de milho e um suplemento protéico, sobre a concentração de nitrogênio amoniacal no líquido ruminal de animais consumindo feno com baixa concentração de PB na matéria seca. O uso do suplemento protéico e também dos dois níveis de milho elevou a concentração de nitrogênio amoniacal em relação à concentração obtida nas amostras de líquido ruminal, colhidas dos animais que não foram suplementados. Ressalta-se que, nesse experimento as concentrações de 
nitrogênio amoniacal no líquido ruminal de animais suplementados estiveram dentro da amplitude de $2 \mathrm{mg} \mathrm{dL}^{-1}$ a $5 \mathrm{mg} \mathrm{dL}^{-1}$, fato não observado para os animais não suplementados. Quando foram avaliadas as concentrações ao longo do tempo, demonstrou-se valores mais elevados, no período de 1 a 7 horas, após a suplementação.

Efeito contrário foi observado por Olson et al. (1999) quando utilizaram amido e proteína degradável no rúmen, como suplementos, em dietas de novilhos consumindo feno de baixa qualidade (4,9\% de PB). Esses autores observaram que o incremento nos niveis de amido na dieta provocaram a redução na concentração de amônia, mesmo quando os animais receberam proteína degradável no rúmen. Entretanto, os níveis de amônia aferidos nesse experimento foram abaixo do mínimo $\left(2 \mathrm{mg} \mathrm{dL}^{-1}\right)$ mencionado por Satter \& Slyter (1974). As concentrações de nitrogênio amoniacal no líquido ruminal de novilhos suplementados com $0,5 \mathrm{~kg}$ de sorgo floculado ou $0,5 \mathrm{~kg}$ de farelo de soja, e de animais sem suplementação, foram avaliadas por Krysl et al. (1989). Esses autores observaram aumento significativo $(p<0,05)$ na concentração média de $\mathrm{N}-\mathrm{NH}_{3}$ no rúmen dos animais suplementados com proteína $(13,5 \mathrm{mg}$ $\left.\mathrm{dL}^{-1}\right)$ comparados aos do tratamento controle $\left(9,9 \mathrm{mg} \mathrm{dL}^{-1}\right)$ e com sorgo floculado $\left(8,7 \mathrm{mg} \mathrm{dL}^{-1}\right)$. O uso do suplemento energético tendeu a diminuir a concentração de amônia no rúmen (Krysl et al. 1989).

Bodine et al. (2000a) avaliaram uso de quatro tipos de suplementos para novilhos pastejando forragens com teor de PB variando entre 13,7 e 5,3\% durante um ensaio de suplementação com duração de 96 dias. Os tratamentos utilizados foram: milho + farelo de soja (MFS); milho + casca de soja (M) apenas para ajustar o nivel de NDT do MFS; farelo de soja (FS) e o controle, à base de casca de algodão (CONT), fornecidos a uma taxa de 1,$3 ; 1,3 ; 0,4$ e $0,06 \%$ do peso vivo, respectivamente. Os niveis de nitrogênio amoniacal ruminal foram elevados pelo fornecimento dos três suplementos em relação ao controle. Entretanto, não houveram diferenças significativas entre os niveis de amônia no líquido ruminal em relação aos três suplementos fornecidos. As 
concentrações médias de amônia aferidas nesse ensaio foram de 5,2; 6,7; 9,0 e $1,3 \mathrm{mg} \mathrm{dL}^{-1}$, para os tratamentos MFS, MI, FS, e CONT, respectivamente. Observou-se que, apenas o tratamento controle apresentou valor abaixo da amplitude estabelecida de 2 a $5 \mathrm{mg} \mathrm{dL}^{-1}$.

Jones et al. (1988) observaram níveis de amônia ruminal médios de 16 a $21,7 \mathrm{mg} \mathrm{dL}^{-1}$ para bovinos recebendo feno de capim bermuda (Cynodon dactylon) com $12,1 \%$ de PB na matéria seca. O fornecimento de $0,3 \%$ do peso vivo dos animais, em milho moído, não apresentou efeito significativo sobre a concentração média de nitrogênio amoniacal no líquido ruminal dos animais. Entretanto, Brake et al. (1989) encontraram valores médios para a concentração de amônia ruminal para animais consumindo feno de capim bermuda (Cynodon dactylon) inferiores aos obtidos por Jones et al. (1988). Os valores observados por Brake et al. (1989) variaram entre 2,5 a $3,4 \mathrm{mg} \mathrm{dL}^{-1}$. No experimento conduzido por Brake et al. (1989) os autores encontraram efeito do tipo de grão utilizado na suplementação dos animais, sem efeito significativo entre os suplementos energéticos utilizados, nos níveis de nitrogênio amoniacal no rúmen. Os valores obtidos foram de 3,$4 ; 5,8$ e $2,5 \mathrm{mg} \mathrm{dL}^{-1}$, para os tratamentos controle (sem suplemento), $0,64 \%$ do peso vivo em cevada moída e $0,60 \%$ do peso vivo em milho moído, respectivamente.

A utilização de grão de sorgo fornecido em níveis de 0,17; 0,32 e 0,66\% do peso vivo, não influenciou o concentração média de amônia ruminal de novilhos recebendo forragem com $6,1 \%$ de PB na matéria seca (Vanzant et al. 1990). Os valores médios observados foram de $4,26 \mathrm{mg} \mathrm{dL}^{-1}$ para a dieta sem suplemento, e de 2,92; 2,94; e 4,92 $\mathrm{mg} \mathrm{dL}^{-1}$ para os tratamentos que receberam grãos de sorgo em níveis de 0,$17 ; 0,32$ e $0,66 \%$ do peso vivo (PV), respectivamente. Vanzant et al. (1990) em outro ensaio utilizaram $0,37 \%$ do PV de animais suplementados com milho, sorgo e trigo para novilhos consumindo forragens colhidas e fornecidas em cochos. Constataram que o uso de trigo resultou em maiores concentrações de nitrogênio amoniacal quando comparado ao controle e ao sorgo, nos tempos de 0,1 e 3 horas após a suplementação, 
apresentando também maiores concentrações de nitrogênio amoniacal ruminal quando comparado ao milho nos tempos de 1 e 3 horas após a suplementação. Não foram observadas diferenças nos tempos de 6 e 9 horas após a suplementação, mas valores superiores de nitrogênio amoniacal no líquido ruminal foram observados em 12 horas após a suplementação com milho, comparado aos resultados observados nos tratamentos controle e grão de sorgo. Vanzant et al. (1990) atribuíram aos diferentes potenciais relativos de degradação ruminal, apresentados pelos grãos, como responsáveis pela maior concentração de nitrogênio amoniacal no líquido ruminal.

Pordomingo et al. (1991) forneceram 0,2; 0,4 e 0,6\% do PV de animais em milho laminado, para novilhos pastejando forragem de verão, com 9,3 a $11,62 \%$ de PB. Foram observadas interações entre tratamento, período e horário de amostragem, para a concentração de nitrogênio amoniacal no líquido ruminal. Durante o primeiro período, a concentração de nitrogênio amoniacal ruminal foi reduzida às $-2,0$ e 10 após a suplementação. Durante o segundo período, observou-se um efeito contrário ao apresentado no primeiro período, onde as concentrações de amônia foram elevadas, uma hora após, para os tratamentos com 0,$2 ; 0,4$; e $0,6 \%$ de milho no $\mathrm{PV}$ em relação comparada ao tratamento controle. As razões para este comportamento não são claras, segundo os autores. A concentração de amônia no fluido ruminal dos animais variou entre 3,8 a $12,4 \mathrm{mg} \mathrm{dL}^{-1}$.

Elizalde et al. (1998) avaliou uso de dois tipos de energia suplementar, milho $(M)$ e gérme de milho (GM), além de uma mistura de amido de milho e farelo de glúten (AFG), para novilhos pastejando festuca com $14 \%$ a $20 \%$ de PB na matéria seca. Os níveis de amônia ruminal estiveram em 21,9; 18,5; 19 ,8 e $20 \mathrm{mg} \mathrm{dL}^{-1}$ para os tratamentos controle, $M, G M$ e AFG. Houve redução na concentração de nitrogênio amoniacal $(P=0,09)$ nos tratamentos que receberam milho e gérmen de milho quando comparados ao controle. Não houve diferença significativa para as concentrações de nitrogênio amoniacal entre os dois tipos de suplementos energéticos, e nem entre os tratamentos 
contudo suplementos energéticos e o tratamento com mistura protéica energética (AFG). Em outro experimento Elizalde et al. (1999a) observaram efeito linear do uso de níveis crescentes, $0 ; 0,4 ; 0,8$; e 1,2\% do PV em milho moído, para animais recebendo alfafa fresca. Os níveis de nitrogênio amoniacal determinados no líquido ruminal dos animais foram, 34,5; 30,9; 27,9 e $24,5 \mathrm{mg}$ $\mathrm{dL}^{-1}$ para os tratamentos $0 ; 0,4 ; 0,8$ e $1,2 \%$ de milho moído em relação ao peso vivo.

Detmann et al. (2001) avaliaram a concentração de nitrogênio amoniacal no líquido ruminal de bovinos recebendo suplementação em pastagens de capim braquiária (Brachiaria decumbens), sob lotação contínua, e com alta disponibilidade de forragem, sem impedir o pastejo seletivo durante o período das águas. Foram utilizados dois tipos de suplementos, milho + farelo de soja (MFS) e farelo de trigo + farelo de soja (TFS), fornecidos em dois niveis, 1 e 2 $\mathrm{kg}$ de suplemento por animal por dia, constituindo em quatro tratamentos (MFS1, MFS2, TFS1 e TFS2), comparados a um grupo controle sem suplementação. Houve efeito significativo $(P<0,01)$ da concentração de nitrogênio amoniacal para suplemento, tempo e interação tempo $x$ coleta, ao serem avaliados líquidos ruminais coletados às $0,2,4$ e 6 horas após a suplementação. O uso de TFS2 resultou em niveis mais elevados de amônia nos tempos 2, 4 e 6 horas após a suplementação, enquanto MS1 não se diferenciou do controle em todos os tempos avaliados. Os outros tratamentos não diferiram dos demais no tempo 0 e apresentaram valores intermediários, as 2,4 e 6 horas após a suplementação. As concentrações de nitrogênio amoniacal sempre estiveram acima de $5 \mathrm{mg} \mathrm{dL}^{-1}$ para todos os tratamentos e horários amostrados. Apenas os tratamentos controle e MS1 não atingiram 10 $\mathrm{mg}$ dL sugerido por Leng (1990). Ressalta-se que os maiores valores foram obtidos pelo uso de $2 \mathrm{~kg} \mathrm{dia}^{-1}$ de farelo de trigo + farelo de soja, as 2 horas $\left(20,1 \mathrm{mg} \mathrm{dL}^{-1}\right)$ e as 4 horas $\left(22,2 \mathrm{mg} \mathrm{dL}^{-1}\right)$ após o fornecimento do suplemento. O grupo controle apresentou concentrações de nitrogênio amoniacal no líquido ruminal, variando de 6,6 a $7,8 \mathrm{mg} \mathrm{dL}^{-1}$. Detmann et al. (2001) responsabilizaram 
a maior degradação da proteína do farelo de trigo pela concentração mais elevada de nitrogênio amoniacal no líquido ruminal, principalmente no tratamento com $2 \mathrm{~kg}$ de suplemento, que propiciou maior ingestão de PB pelos animais, e consequentemente maior proporção de proteína degradável no rúmen. Aumentos na concentração de amônia ruminal foram obtidos por Mathis et al. (2000) à medida que se elevou o nível de proteína degradável no rúmen de 0 para $0,124 \%$ do PV dos animais, fornecida via suplemento, para novilhos estabulados recebendo feno de capim bermuda (Cynodon dactylon) com 8,2\% de PB na matéria seca. Del Curto et al. (1990) observaram efeito no nível de proteína no suplemento (sorgo + farelo de soja) sobre a concentração de amônia ruminal às 3,6 e 9 horas após a suplementação $(p<0,10)$, para animais recebendo feno com concentração de PB semelhante a apresentada pelo volumoso utilizado por Mathis et al. (2000). Entretanto essas diferenças não ocorreram as 0 e 12 horas após a suplementação.

Valores superiores aos encontrados por Detmann et al. (2001) para pastagens tropicais, foram observados por Branine \& Galyean (1990), em pastagens de trigo (Triticum aestivum), com concentrações de PB na MS superiores a $20 \%$. Estes autores relataram 9,9 a $37,9 \mathrm{mg} \mathrm{dL}^{-1}$ de $\mathrm{N}-\mathrm{NH}_{3}$ no líquido ruminal para animais sem suplementação. Nesse experimento o fornecimento de $0,5 \mathrm{~kg}$ por novilho por dia de milho reduziu as concentrações de amônia em determinados horários a mostrados.

Efeito do processamento do grão de milho sobre as concentrações de nitrogênio amoniacal no rúmen, de animais alimentados com feno de bermuda (Cynodon dactylon) foram relatadas por Galloway et al. (1993), quando compararam o milho moído e milho inteiro. Esses autores observaram que o milho moído apresentou menores valores na concentração de nitrogênio amoniacal no líquido ruminal, as 8 horas após a suplementação, enquanto o contrário foi observado apenas no líquido colhido as 20 horas após a suplementação. Observou-se que a moagem pode ter acelerado a degradação do amido no rúmen quando comparado ao grão inteiro, propiciando assim, o 
uso do nitrogênio amoniacal pelos microrganismos ruminais em horários mais próximos do momento da suplementação. Soriano et al. (2000) também observaram efeito da disponibilidade do amido no conteúdo ruminal sobre a concentração de nitrogênio amoniacal no líquido ruminal de vacas leiteiras recebendo $6 \mathrm{~kg}$ de milho como suplemento em pastagens de elevado valor nutritivo ( $>20 \%$ de PB e $53 \%$ de FDN na MS).

\subsection{2 $\mathrm{pH}$ ruminal}

A digestão ruminal da fibra depende da manutenção do $\mathrm{pH}$ ruminal em uma amplitude estreita (Dixon \& Stockdale 1999). Conforme exposto por estes autores em extensa revisão, a faixa de $\mathrm{pH}$ para garantir uma ótima fermentação ruminal da parede celular dos alimentos seria de 6,6 a 7,0. Segundo Dixon \& Stockdale (1999) a digestão da fibra é intensamente reduzida quando o $\mathrm{pH}$ do fluido ruminal for inferior a 6,2, e mínima, quando os valores apresentados forem inferiores a 6,0. Redução na ingestão de forragem associada ao fornecimento de grãos ricos em amido ocorre em função da redução do $\mathrm{pH}$, a valores inferiores a 6,5 , ou através do efeito direto do carboidrato sobre a flora ruminal (Hoover, 1986; Yokoyama \& Jonhson, 1988; Cardoso, 1996). Analisando o trato digestivo total, dietas com altos níveis de amido degradável no rúmen, indicaram uma redução na digestibilidade dos carboidratos estruturais. No rúmen, a digestão de FDN e FDA reduziu em média 14,1\% quando fontes de maior degradabilidade de amido foram utilizadas (Nussio, 1997). Outro efeito marcante do $\mathrm{pH}$ na fermentação ruminal seria sobre as perdas de nitrogênio amoniacal, que são mais elevadas quando há condição de acidez ruminal, ocasionadas pela redução na taxa de degradação da fibra (Hoover 1986).

Há outros fatores que afetam o $\mathrm{pH}$ ruminal, dentre eles, a produção de ácidos graxos voláteis (AGVS). Quando essa é mais rápida que sua absorção, acarreta em reduções no $\mathrm{pH}$, enquanto a secreção salivar tende a manter o pH 
(Dixon \& Stockdale 1999). A quantidade de saliva secretada depende da característica física da forragem, mas também varia amplamente entre animais (Franklin et al. 1981). Forragens imaturas, particularmente as leguminosas, apresentam alguma capacidade tamponante (Dixon \& Stockdale, 1999).

Vários trabalhos analisaram o efeito do fornecimento de fontes energéticas e protéicas em suplementos para pastagens sobre o $\mathrm{pH}$ ruminal. $\mathrm{O}$ uso de três fontes de carboidratos (glicose, amido e fibra) em dois niveis $(0,15 \mathrm{e}$ $0,30 \%$ do PV) associados a dois níveis de proteína degradável no rúmen $(0,031$ e $0,122 \%$ do $P V$ ) influenciou os valores médios de $\mathrm{pH}$ ruminal de bovinos recebendo feno de baixo valor nutritivo $(5,7 \%$ de PB). Várias interações ocorreram, entretanto, os valores apresentados pelos animais suplementados situaram-se entre 6,4 e 6,7, provavelmente causando efeito mínimo sobre a digestão de fibras (Heldt et al. 1999). Olson et al. (1999) variaram as quantidades de amido (0; 0,15 e $0,30 \%$ do PV) associadas a alterações nas quantidades de proteina degradável no rúmen $(0,03 ; 0,06 ; 0,09$ e $0,12 \%$ do PV), e observaram reduções lineares no $\mathrm{pH}$ ruminal para os niveis de amido e proteína degradável no rúmen, refletindo em aumento na atividade da fermentação ruminal. Entretanto, em nenhum dos tratamentos propostos $\mathrm{opH}$ observado foi inferior a 6,2, o que evitaria a depressão na digestibilidade da fibra. Nesse experimento, houve efeito linear do nivel de amido no suplemento, sobre a digestão da parede celular. Caton \& Dhuyvetter (1997) sugeriram que a depressão do $\mathrm{pH}$ ruminal, nem sempre, explica totalmente as reduções na ingestão e digestão, observadas constantemente em dietas de gado de corte a base de forragem, e suplementadas com grãos. Esses resultados corroboram com os obtidos por Sutton et al. (1987) em alimentação de vacas leiteiras.

Vanzant et al. (1990) observaram decréscimo linear no $\mathrm{pH}$ ruminal de $(\mathrm{P}$ $<0,01$ ) de novilhos de corte pastejando forragens contendo $11,9 \%$ de PB, recebendo niveis crescentes de grão de sorgo inteiro $(0 ; 0,45 ; 0,91$ e $1,82 \mathrm{~kg}$ por cabeça por dia). Entretanto, os valores obtidos sempre situaram-se acima de 6,45 , mesmo sob o nivel mais alto de suplementação. Pordomingo et al. 
(1991) suplementaram animais consumindo pastagens de bom valor nutritivo com niveis crescentes de grãos de milho inteiros $(0 ; 0,2 ; 0,4$ e $0,6 \%$ do PV) e não observaram efeito do suplemento sobre o $\mathrm{pH}$ ruminal. $\mathrm{O} \mathrm{pH}$ ruminal variou entre 6,0 e 6,4; apresentando média de 6,3.

$\mathrm{O}$ efeito do uso de suplementos energéticos sobre o $\mathrm{pH}$ do fluido ruminal de bovinos em pastagens tropicais foi avaliado por Brake et al. (1989). Esses autores utilizaram milho moído ( $0,60 \%$ do PV) ou cevada moída ( $0,64 \%$ do PV) e observaram uma redução do $\mathrm{pH}(\mathrm{p}<0,05)$ para animais suplementados. Os valores mensurados de $\mathrm{pH}$ foram 6,77; 6,62 e 6,67, para animais sem suplementação, suplementados com cevada a $0,64 \%$ do PV e suplementados com milho a $0,60 \%$ do $\mathrm{PV}$.

Bodine et al. (2001) compararam o uso de suplementos à base de fontes de fibra, de grãos e de uma fonte de proteina, fornecidos para novilhos recebendo feno de capim bemuda (Cynodon dactylon). Verificaram que houve efeito dos suplementos sobre $\mathrm{o} \mathrm{pH}$ ruminal, quando foram comparados os tratamentos com e sem suplementação. Entretanto, não houve efeito significativo do tipo de suplemento energético, fibra ou grão, sobre o valor do $\mathrm{pH}$ ruminal que foi de 6,44 para grãos e 6,42 para o suplemento com fibra. $O$ valor médio obtido de $\mathrm{pH}$ para o grupo sem suplementação foi de 6,81, e para o grupo suplementado com proteína foi de 6,64. Resultados semelhantes foram obtidos por Elizalde et al. (1998) que compararam o uso de suplementos à base de milho, farelo de glúten de milho (21\% de PB) e uma mistura de amido de milho + glúten de milho (66\% de PB) em novilhos pastejando forragem de alto valor nutritivo. Não foram observadas diferenças significativas entre os suplementos utilizados, bem como, entre o tratamento controle e os tipos de suplementos. $\mathrm{O} \mathrm{pH}$ observado foi de 6,3 para todos os tratamentos com suplementos e de 6,4 para o grupo sem suplementação. Não houve efeito da suplementação sobre a digestibilidade da forragem, porém observou-se redução na ingestão de forragem. Bodine et al. (2000a) observaram redução do $\mathrm{pH}$ ruminal de 6,4 para 6,1 em animais suplementados com milho ou milho + 
farelo de soja em relação ao controle. Nesse experimento ficou estabelecido que a inclusão de amido provocou a redução do $\mathrm{pH}$ ruminal, para um valor que, provavelmente, não prejudique a digestão da fibra da forragem pastejada. Entretanto, nos dados obtidos por Krysl et al. (1989) não foi observado efeito significativo do tipo de suplemento, protéico ou energético, sobre o $\mathrm{pH}$ ruminal $(6,3)$ quando comparado ao controle.

Outros trabalhos observaram efeito do uso de suplementos sobre os valores de $\mathrm{pH}$ no líquido ruminal de bovinos estabulados recebendo forragens (Chase \& Hibberd 1987; Jones et al. 1988; Sanson et al. 1990; Galloway et al. 1993) ou em pastejo (Soriano et al. 2000; Detmann et al 2000; Detmann et al. 2001), suplementados com grãos elou fontes de proteína.

Chase e Hibberd (1987) observaram efeito da quantidade de suplemento (milho moído) sobre o $\mathrm{pH}$ ruminal de novilhas. $\mathrm{O} \mathrm{pH}$ ruminal de animais recebendo 2 ou $3 \mathrm{~kg}$ de milho foi inferior ao controle (sem suplemento), das 3 as 12 horas após a suplementação. Não houve diferença significativa entre o controle e o tratamento em que os animais foram suplementados com $1 \mathrm{~kg}$ de milho por cabeça por dia, estando os valores médios encontrados acima de 6,2.

Sanson et al. (1990) avaliaram o fornecimento de suplemento protéico à base de proteína de glúten de milho, suplemento protéico/energético contendo milho, e um outro suplemento protéico/energético com maior proporção de milho. Os autores observaram que a inclusão do milho nos suplementos provocou redução no valor do $\mathrm{pH}$ ruminal para níveis inferiores a 6 , nos tempos de $3,5,7$ e 9 horas após o fornecimento do suplemento. Os tratamentos controle e suplemento protéico, apresentaram valores de $\mathrm{pH}$ acima de 6 . Os autores observaram ainda que a suplementação provocou reduções estatisticamente significativas $(P<0,05)$ no pH do líquido ruminal, após $1,3,5$ e 7 horas da suplementação, em comparação ao tratamento controle. Galloway et al. (1993) avaliaram a suplementação de animais consumindo feno de capim bermuda ( $1,5 \%$ do PV) com $0,7 \%$ do PV em grãos. Os autores registraram valores de $\mathrm{pH}$ ruminal de 5,95 e 5,99, após 8 e 14 horas a suplementação com 
milho moído. Observaram também valores de pH de 5,94 após 14 horas da suplementação com grãos de milho inteiro. Esses resultados refletem a diferença na degradabilidade do amido em função do processamento do milho (Theurer. 1986). Quando os animais receberam trigo como suplemento, o pH de 5,73 foi registrado após 8 horas da suplementação, enquanto a utilização de grãos de sorgo não gerou valores de $\mathrm{pH}$ inferiores a 6, em nenhum dos tempos estudados (Galloway et al. 1993). Essas observações demonstram o efeito do tipo de grão sobre a disponibilidade do amido rúmen. Segundo Poppi \& McLennan (1995) o amido do trigo é mais disponivel para fermentação ruminal que o amido do milho, que por sua vez é mais prontamente fermentável que o amido do sorgo. No estudo realizado por Galloway et al. (1993) a digestibilidade do amido no trato digestivo total observada nos suplementos avaliados, foi de 94,$8 ; 87,3 ; 82,3$ e $73,7 \%$ para o trigo, milho moído, milho grão inteiro e grão de sorgo, respectivamente.

Entretanto, o uso do grão de milho ensilado com alta umidade comparado ao milho moído grosso, como suplemento para pastagens de elevado valor nutricional, não demonstrou diferença sobre o $\mathrm{pH}$ ruminal (Soriano et al. 2000). Os autores forneceram $6 \mathrm{~kg}$ por vaca por dia de milho e observaram que o menor valor de $\mathrm{pH}$ registrado foi de 5,8 as 8 horas após a suplementação. Variações ocorreram entre 5 e 8 horas após o fornecimento do suplemento e foram influenciadas por turnos de ruminação. Soriano et al. (2000) sugeriram que as reduções no $\mathrm{pH}$ do líquido ruminal foram afetadas mais pela fermentação da forragem que pela fermentação do amido contido nos suplementos. Essa mesma observação foi feita por Ribeiro Filho et al. (1999) que relacionaram menores valores do $\mathrm{pH}$ ruminal com atividades de pastejo e ruminação ao longo do dia para bovinos, ingerindo exclusivamente forragem.

Detmann et al. (2000) avaliaram o uso de quantidades elevadas de suplementos à base de milho com uréia contendo caroço de algodão, farelo de soja, grão de soja integral ou grão de soja moída como fontes de proteína 
verdadeira vegetal, fornecidos ao nível de $1 \%$ do peso vivo, para terminação de bovinos em pastagens diferidas de Brachiaria decumbens $(2,52 \%$ de PB). Segundo os autores, o uso desses suplementos, normalmente empregados na terminação de bovinos em pastejo, não foi capaz de alterar o $\mathrm{pH}$ ruminal negativamente, ou seja, abaixo de 6 . Nenhum dos tratamentos apresentou pH ruminal inferior a 6,5 nos tempos de 0 a 6 horas após o fornecimento do suplemento.

Detmann et al. (2001) não encontrou diferenças entre as fontes de energia, milho (amido) ou farelo de trigo (fibra de alta digestão), e nem das quantidades de suplementos (1 ou $2 \mathrm{~kg}$ por cabeça por dia) sobre os valores de $\mathrm{pH}$ ruminal. O único efeito significativo foi o horário de coleta. Na curva de regressão do $\mathrm{pH}$ em relação ao tempo após o fornecimento do suplemento, observou-se valor mínimo de 6,32, ocorrendo 3,2 horas após a suplementação. Esses resultados estão condizentes com os observados por Hess et al. (1996) que não observaram efeito da quantidade de farelo de trigo $(0,34$ contra $0,48 \%$ do PV) e nem do tipo de suplemento (milho vs farelo de trigo) sobre $\mathrm{opH}$ ruminal. Nesse experimento o $\mathrm{pH}$ ruminal aferido foi de 6,$1 ; 6,0 ; 6,0$; e 5,9; para os tratamentos controle, milho $0,34 \% \mathrm{PV}$, farelo de trigo $0,34 \% \mathrm{PV}$ e farelo de trigo $0,48 \%$ PV, respectivamente. Segundo Catton \& Dhuyvetter (1997) fontes energéticas fibrosas tendem a resultarem em $\mathrm{pH}$ do líquido ruminal similares aos de grãos. Os autores afirmaram que a queda de $\mathrm{pH}$ está vinculada mais ao nível de suplementação, que propriamente a fonte utilizada.

\subsubsection{Perfil da concentração de ácidos graxos voláteis}

No rúmen ocorre digestão parcial dos açúcares ingeridos, por microrganismos ruminais, através de processo anaeróbio, os quais liberam produtos intermediários denominados de ácidos graxos voláteis (AGVs), que recebem esta denominação por se tratarem de ácidos orgânicos de cadeia, reduzida voláteis sob alta temperatura (Allen, 1997). A temperatura ruminal é 
insuficiente para permitir a volatilização desses compostos, mantendo todos em solução no líquido ruminal até o momento da absorção.

Esses AGVs são absorvidos por difusão através da parede ruminal, participando do metabolismo energético dos animais como principais fontes de energia (Van Soest, 1994). Após a absorção, os AGVs são utilizados de diferentes formas, sendo o ácido acético utilizado parcialmente como fonte de energia pela a parede ruminal, e o restante direcionado para a corrente sanguínea, após passar pelo fígado, chegando aos demais tecidos do organismo onde é utilizado como fonte de energia ou precursor de gordura (Bergman, 1990). O propionato após a absorção, é levado ao fígado, onde é quase totalmente utilizado pelos hepatócitos para atender a gluconeogênese, caracterizando-se como o principal precursor de glucose nos animais ruminantes (Huntington et al. 1981; Amaral et al. 1990). O ácido ácido butírico é utilizado na sua maioria como fonte de energia para a própria parede ruminal, chegando apenas $10 \%$ do total absorvido até o fígado, para ser utilizado na sintese de ácidos graxos de cadeia longa, corpos cetônicos e $\mathrm{CO}_{2}$. A disponibilidade de butirato para os outros tecidos é muito limitada, sendo esse AGV utilizado para a síntese de gordura no tecido adiposo e glândula mamária (Bergman, 1990).

O aumento na degradação ruminal de amido causa um aumento na concentração total de ácidos graxos voláteis, de acordo com Simas (1995) e Chen (1994). A floculação estimula o aumento na concentração de AGV total, principalmente pelo aumento no nivel de propionato, reduzindo a proporção acetato:propionato (Theurer et al., 1996). Lima (2000) observou aumento na concentração de propionato, redução na relação acetato:propionato e aumento na concentração de ácidos graxos voláteis, quando comparou o milho floculado com milho moído grosso, como fontes de amido para bovinos recebendo capimelefante (Pennisetum purpureum) picado, colhido através de pastejo simulado. Joy et al. (1997); Lykos et al. (1997); Menezes Jr. (1999), observaram aumento na concentração de propionato, redução na relação acetato:propionato, sem 
elevação na concentração total de AGVs. Soriano et al. (2000) forneceram 6 kg $\mathrm{dia}^{-1}$ de milho de alta umidade ou milho moído grosso para vacas em lactantes em pastejo, e não observaram alterações na concentração molar de AGV total, nem na proporção molar de acetato e propionato obtidas, que foram de $66 \%$ e $19 \%$, respectivamente.

Niveis decrescentes de milho como suplementos para dietas à base de feno de baixo valor nutritivo não influenciaram a concentração total de AGVs e a proporção molar de propionato no rúmen, enquanto a proporção molar de acetato foi reduzida linearmente $(P<0,05)$ com o incremento na quantidade de concentrado, provocando uma tendência de queda na relação acetato:propionato $(P<0,10)$ (Chase Jr. \& Hibberd, 1987).

Vanzant et al. (1990) observaram que aumentos na quantidade de sorgo grão, como suplemento, para novilhos alimentados com forragem oferecida no cocho, apresentaram decréscimo linear na proporção de acetato $(P=0,01)$, sem alterações na concentração de ácido propiônico. Nesse experimento a relação acetato:propionato variou entre 5,96 a 6,24, sem apresentar efeito estatisticamente significativo dos tratamentos. Pordomingo et al. (1991) não observaram efeito $(P>0,10)$ de níveis crescentes de milho inteiro $(0 ; 0,2 ; 0,4 \mathrm{e}$ $0,6 \%$ do PV) sobre a concentração total de AGV's e nem sobre as proporções molares de acetato, propionato e butirato no líquido ruminal de novilhos de corte pastejando forragem de elevado valor nutritivo. As concentrações de AGV's totais variaram entre 103,4 a $112,1 \mathrm{mM}$.

$\mathrm{O}$ uso de pequena quantidade de sorgo floculado $\left(0,5 \mathrm{~kg} \mathrm{cab}^{-1} \mathrm{dia}^{-1}\right)$ diminuiu a proporção molar de acetato $(P<0,05)$, sem alterar a concentração de AGV's e a concentração molar de propionato $(P>0,10)$ para animais pastejando forragem de bom valor nutritivo (Krysl, et al. 1989). O mesmo comportamento foi observado para os animais que receberam suplementação protéica à base de $0,5 \mathrm{~kg} \mathrm{cab}^{-1} \mathrm{dia}^{-1}$ de farelo de soja. Não houve diferença entre a suplementação protéica e energética. As proporções molares de acetato foram de 71,4 e $70,5 \mathrm{~mol} 100 \mathrm{~mol}^{-1}$, enquanto as proporções molares de 


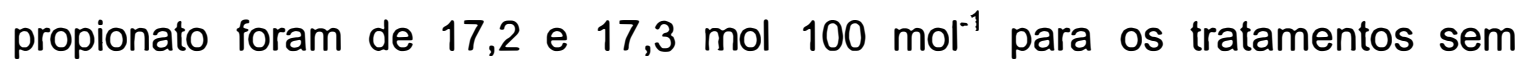
suplemento e suplementado com sorgo floculado, respectivamente.

Del Curto et al. (1990) avaliou a suplementação protéica de novilhos consumindo forragem com 8 a $9 \%$ de PB na MS, e observaram reduções lineares na relação acetato:propionato $(P=0,10)$ de 5,07 para 4,90 ; e aumento na proporção molar de propionato $(P=0,08)$ de 14,75 para

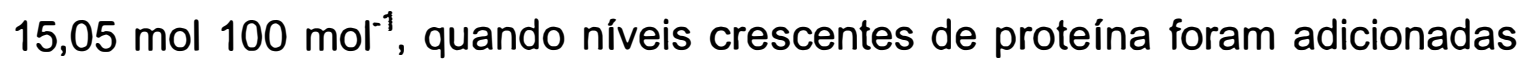
na dieta, através do fornecimento de $0,5 \%$ do PV dos animais, em suplementos à base de sorgo processado fisicamente + farelo de soja, com 13, 25 e $39 \%$ de PB na MS. A alteração da relação acetato:propionato ocorreu em função do aumento linear do ácido propiônico, uma vez que as proporções molares de ácido acético permaneceram inalteradas com a suplementação.

Galloway et al. (1993) compararm diferentes tipos de grãos e formas de processamento do milho, sobre a fementação ruminal de animais recebendo feno de gramínea tropical. Não observaram efeito dos tratamentos sobre a proporção molar de ácido propiônico, que variou entre $17,4 \%$ para o tratamento sem suplemento e $18,4 \%$ para o tratamento com milho inteiro. Entretanto, o uso de trigo elevou a produção de AGV's em relação ao milho grão moído, milho grão inteiro, sorgo inteiro e o controle, que não diferiram entre si. Ressaltou-se que o uso de suplementos energéticos determinou decréscimo na proporção molar de acetato quando comparados ao controle.

Grigsby et al. (1997) avaliaram a substituição da casca de soja por milho moído 0; 33; 66 e 100\% no concentrado, sobre a fermentação ruminal de bovinos alimentados com uma dieta composta por $60 \%$ de feno de gramínea de baixo valor nutritivo e $40 \%$ de concentrado (base da MS). Observaram decréscimo linear $(P<0,01)$ na proporção molar do acetato e aumento linear $(P$ $<0,01$ ) na proporção molar do butirato, com o incremento da participação do milho no concentrado, sem alterar a proporção de propionato e a concentração de AGV's totais.

Hess et al. (1996) compararam duas fontes de energia em suplementos 
para bovinos de corte em pastejo sobre forragem de bom valor nutricional e não observaram diferenças para as proporções molares de acetato e propionato, para a relação acetato:propionato, e também para a concentração de AGV total. Entretanto, quando os autores compararam o efeito do uso dos suplementos contra o tratamento sem suplementação, os níveis de acetato foram reduzidos $(P=0,01)$ acompanhados de elevação na proporção de propionato $(P=0,08)$, causando redução na relação acetato:propionato além do aumento na concentração de $A G V$ total $(P=0,03)$, justificando o maior desempenho dos animais suplementados comparados ao controle.

Elizalde et al. (1999b) observaram efeito linear $(P<0,01)$ de niveis crescentes de milho moído grosso, como suplemento, na dieta de bovinos alimentados com alfafa, sobre a concentração de AGV total, que foi elevada de $79,4 \mathrm{mM}$ no tratamento controle, para valores de 90,3; 94,0 e 94,0 $\mathrm{mM}$ quando o milho foi fornecido a níveis de 0,$4 ; 0,8$ e 1,2\% do PV, respectivamente. As proporções molares de acetato, propionato e butirato também apresentaram efeitos lineares $(P<0,01)$, com o incremento nas quantidades de milho. Os niveis de propionato e o butirato sofreram elevações, enquanto o de acetato apresentou redução. Os autores observaram nesse experimento uma relação linear entre a concentração total de AGV's e o pH ruminal gerando a seguinte equação: $\mathrm{pH}=7,39-0,012 \times \mathrm{AGV}[\mathrm{mM}] \mathrm{P}<0,01, \mathrm{r}^{2}=0,40$.

Entretanto, quando Elizalde et al. (1998) avaliaram o uso de $3,11 \mathrm{~kg} \mathrm{dia}^{-1}$ fibra digestível (farelo de glúten), $3,11 \mathrm{~kg} \mathrm{dia}^{-1}$ de milho moído grosso e $1,55 \mathrm{~kg}$ $\mathrm{dia}^{-1}$ da mistura de amido de milho com proteína do glúten (66\% $\mathrm{PB}$ ), como suplementos para animais pastejando capim festuca, não observaram alterações na concentrações totais de AGV's, nas proporções molares de acetato, propionato e butirato. Os valores médios encontrados nas proporções de acetato, propionato e butirato foram, de 61,6; 17,6 e 11,0 mol 100 $\mathrm{mol}^{-1}$. Os autores observaram que a suplementação não reduziu a digestão da festuca, embora tenha diminuido a ingestão de forragem, demonstrando assim efeito de substituição. 
Heldt et al. (1999) observaram incremento na concentração de AGV's totais com o uso de suplementos para animais recebendo feno de gramíneas de baixo valor nutritivo. Houve efeito positivo do nível de proteína degradável no rúmen ( $P D R)(P<0,01)$, o que foi justificado pela baixa concentração de $P B$ na matéria seca da forragem, que limitou o digestão ruminal. Nesse caso, o incremento dos níveis de carboidratos nos suplementos, não apresentou resposta positiva $(P=0,40)$, entretanto, diferenças evidentes ocorreram quando as fontes de carboidratos $(\mathrm{CHO})$ foram comparadas. $\mathrm{O}$ uso de fontes de fibra de alta qualidade nos suplementos aumentou ligeiramente $(P=0,06)$ a concentracão de AGV total, quando comparada à glucose como fonte de $\mathrm{CHO}$. Do mesmo modo, o uso de amido induziu ao aumento $(P=0,07)$ na concentração de AGV total quando comparado aos suplementos com outras fontes de $\mathrm{CHO}$.

Em relação às proporções de AGV's Heldt et al. (1999) observaram reduções nas proporções de acetato $(P<0,01)$ à medida que os niveis de PDR e $\mathrm{CHO}$ aumentaram nos suplementos. Houve também redução $(P<0,01)$ na proporção molar do acetato quando utilizou-se glucose em vez de fibra de alta qualidade nos suplementos. As proporções de butirato foram elevadas pelo uso de suplementos $(P=0,02)$, principalmente quando o nível de $\mathrm{CHO}$ foi elevado $(P<0,01)$. O nível de proteína degradável no rúmen não demonstrou efeito sobre a proporção molar de ácido butírico $(P=0,48)$. Nos suplementos sem a presença de amido, o uso de glucose elevou $(P<0,01)$ a proporção de butirato comparado ao suplemento à base de fibra. Da mesma forma, o uso de outras fontes de $\mathrm{CHO}$ (glucose ou fibra) demonstraram maiores proporções $(P<0,01)$ de butirato quando comparadas ao uso de amido como fonte de $\mathrm{CHO}$ nos suplementos. O aumento na proporção de butirato coincidiu com redução na proporção de acetato, e isso foi consistente com o fato de ambos terem o AcetilCoA como precursor comum (Heldt et al. 1999). A utilização de proteína degradável no rúmen elevou as proporções de isobutirato, isovalerato e valerato (Heldt et al. 1999). Köster et al. (1996) também observaram elevações nas 
proporções de ácidos graxos voláteis de cadeia ramificada com o uso de níveis crescentes de proteína degradável no rúmen em suplementos. Os níveis de propionato foram elevados quando comparou-se o controle contra os suplementados, porém sem efeito do nível de proteína degradável no rúmen (PDR) ou do tipo de $\mathrm{CHO}$ utilizado nos suplementos (Heldt et al. 1999).

O uso de niveis crescentes de amido e PDR foram avaliados por Olson et al. (1999) em experimentos utilizando feno de gramíneas de baixo valor nutritivo. Os níveis de amido nos suplementos foram de 0; 0,15 e 0,30\% PV, e os niveis de PDR foram de $0 ; 0,03 ; 0,06 ; 0,09$ e $0,12 \%$ do PV. Niveis crescentes de amido provocaram elevação linear $(P<0,01)$ nas proporções de propionato e butirato, acompanhadas de redução linear na proporção de acetato $(P<0,01)$, enquanto que $o$ incremento do nivel de PDR causou elevação linear nas proporções de AGV's de cadeia ramificada $(P<0,01)$. De maneira geral, o uso de suplementos elevou a concentração ruminal de AGVs no líquido ruminal em relação aos valores observados em animais não suplementados, demonstrando que a suplementação estimula a atividade de fermentação dos microrganismos ruminais (Olson et al. 1999). A concentração de $A G V s$ totais foi elevada linearmente $(P=0,02)$ quando o nível de PDR nos suplementos foi aumentada, enquanto que a adição de amido aos suplementos não promoveu incrementos $(P>0,20)$ na concentração de $A G V$ s totais (Olson et al. 1999), demonstrando que o fator limitante na fermentação ruminal de forragens de baixo valor nutritivo é o teor de proteína bruta.

Bodine et al. (2000a) avaliaram o uso de três tipos de suplementos (protéico/energético, energético e protéico) na dieta de bovinos pastejando forragem de médio valor nutritivo $(7,36 \%$ de PB). Não houve efeito da suplementação sobre a concentração de $A G V s$ totais no rúmen. Entretanto, o uso de milho nos suplementos protéico/energético e energético reduziu a proporção molar de acetato $(P<0,05)$, aumentou a proporção molar de propionato $(P<0,05)$, resultando na redução da relação acetato:propionato $(P<$ $0,05)$, quando comparado aos tratamentos sem suplemento e com proteína 
degradável no rúmen (farelo de soja).

O uso de suplementos energéticos, tanto fibra como amido, aumentou a concentração de AGVs totais em relação ao grupo sem suplemento $(P<0,05)$ e ao grupo suplementado com proteína $(P<0,10)$, em novilhos alimentados com feno contendo 5,5\% de PB na MS. Não houve efeito significativo do suplemento protéico sobre a concentração de AGVs totais, embora essa tenha sido elevada de $71,06 \mathrm{mmol} \mathrm{L}^{-1}$, no grupo sem suplemento, para $74,47 \mathrm{mmol} \mathrm{L}^{-1}$ nos animais suplementados com proteína. O uso de fontes de fibra e amido como suplementos elevou a concentração de AGVs totais para $84,25 \mathrm{mmol} \mathrm{L}^{-1} \mathrm{e}$ $86,01 \mathrm{mmol} . \mathrm{L}^{-1}$, respectivamente (Bodine et al. 2001). Esses autores avaliaram as proporções dos AGVs, e observaram que o uso de suplementos energéticos reduziu a proporção de acetato $(71 \%$ contra $67 \%)$, aumentou a proporção de propionato $(19 \%$ contra $22 \%)$ e reduziu a relação acetato:propionato $(3,82$ contra 3,15$)$ comparados ao tratamento com proteina $(P<0,01)$ e ao tratamento contole $(P<0,01)$. A comparação realizada entre as duas fontes de energia apresentou significância de $10 \%$ apenas para a proporção de propionato, que foi ligeiramente superior para o tratamento contendo grãos (amido) quando comparado ao tratamento que continha fibra de alta qualidade no suplemento $(22,6 \%$ contra $21,31 \%)$.

\subsubsection{Degradação ruminal da matéria seca e da fibra}

O rúmen é o local de maior ocorrência de digestão da fibra no sistema digestivo dos ruminantes (Van Soest, 1994). Sendo as forragens tropicais as mais fibrosas, com $60 \%$ a $75 \%$ de parede celular na matéria seca, a digestão ruminal da matéria seca é dependente da digestão da fibra no rúmen (Dixon \& Stockdale, 1999).

Segundo Mertens (1997) a fibra pode ser definida nutricionalmente como sendo a fração lentamente digestível ou a fração indigestível dos alimentos que ocupam espaço físico no trato gastrointestinal dos animais. A porção fibra dos 
alimentos é formada por carboidratos estruturais, que são representados pela fração fibra detergente neutro (FDN), e essa apresenta uma relação inversamente proporcional à densidade energética. Porém, há necessidade de uma quantidade mínima de fibra de boa qualidade, para promover máximo consumo de matéria seca e energia, manter a fermentação ruminal e prevenir distúrbios metabólicos nos animais (Hoover 1986; NRC, 1989).

A digestão da fibra no rúmen é um processo dinâmico que envolve a aderência e a fermentação dos polissacarídeos da parede celular pelos microrganismos. A extensão da digestão da fibra é caracterizada pela proporção de fibra potencialmente digestivel, e das taxas de digestão e de passagem no rúmen (Allen \& Mertens, 1988). A taxa e a extensão da digestão dos carboidratos estruturais são comprometidas pela queda acentuada do $\mathrm{pH}$, decorrente da maior produção de ácidos orgânicos durante a fermentação de carboidratos não estruturais, que estimulam o aumento da taxa de crescimento de bactérias não celulolíticas, que devem competir com vantagens sobre as bactérias celulolíticas, resultando em menor degradação da parede celular (Fahey et al. 1988). Entretanto, reduções no pH parecem afetar a digestão da fibra parcialmente (Hoover, 1986). Outras fontes de carbono como amido, maltose e manose, afetariam a digestibilidade da fibra (Hoover, 1986; Haddad \& Grant, 2000), independente do efeito do $\mathrm{pH}$.

Em dietas exclusivas de forragem, a digestão da parede celular está associada ao teor de lignina ou até mesmo à quantidade de determinados constituintes da lignina como os ácidos p-cumárico e ferúlico (Jung \& Fahey, 1984). Segundo Akin (1982) estes componentes da lignina deprimem o crescimento dos microrganismos "in vitro".

Hoover (1986), em extensa revisão de literatura, observou que a adição de carboidratos rapidamente fermentáveis, em dietas com forragem, reduziu a digestão da fibra em experimentos "in vivo" e "in vitro". Segundo esse autor, a quantidade de $10 \%$ a $15 \%$ de carboidratos rapidamente fermentáveis no rúmen seria suficiente para promover queda na digestão da fibra, embora severas 
depressões são comumente associadas à niveis de $30 \%$ de inclusão de grãos, ou outras formas de carboidratos rapidamente fermentáveis. Entretanto, alguns trabalhos não apresentaram efeito da inclusão de carboidratos não estruturais sobre a taxa e a degradabilidade efetiva da matéria seca de forragens tropicais (Berchielli et al. 1996) e sobre a fração potencialmente degradável da FDN de gramíneas temperadas ensiladas (De Visser et al. 1998).

Euclides et al. (1999) observaram valores de degradabilidade "in situ" da matéria seca do capim Tanzânia (Panicum maximum), após 96 horas de incubação, de $70,2 \%$ no verão e $67,1 \%$ no inverno $(P<0,05)$,sem o uso de suplementos para os animais.

Segundo Dixon \& Stockdale (1999) a utilização de suplementos contendo carboidratos não estruturais exerce efeito negativo mais acentuado sobre forragens de menor valor nutritivo. Leventine et al. (1990) observou que a degradabilidade potencial e a taxa de degradabilidade da MS foram maiores para forragens de melhor qualidade, quando comparada às de menor qualidade, quando foram incluídos niveis crescentes de concentrados na dieta. Esses autores também observaram efeito linear do nível de concentrado sobre a degradabilidade potencial da MS e da FDN após 96 horas de incubação.

Além da qualidade da forragem, a origem do suplemento pode ter impacto diferente sobre a degradação da MS e da FDN. Nussio (1997) observou reduções na degradação da MS e FDN, bem como redução nas taxas de degradação destas frações do feno de alfafa, quando o sorgo laminado foi substituido por sorgo floculado em dietas para vacas leiteiras. Resultados semelhantes foram observados por Weiss (1994) e Harmisson et al. (1997). Entretanto, Lima (2000) não observou efeito do processamento do grão (floculação contra moagem fina), sobre a degradabilidade efetiva e a taxa de degradação da MS e da FDN do capim elefante fornecido para vacas em lactação. A degradabilidade efetiva da MS e da FDN do capim elefante foram de $63 \%$ e $62,7 \%$ respectivamente.

Krysl et al.(1989) não observaram efeito do uso de suplemento 
energético (0,5 $\mathrm{kg} \mathrm{cab}^{-1} \mathrm{dia}^{-1}$ de sorgo floculado) e nem do uso de suplemento protéico $\left(0,5 \mathrm{~kg} \mathrm{cab}^{-1} \mathrm{dia}^{-1}\right.$ de farelo de soja) sobre a degradação da FDN nos diferentes tempos de incubação $(P>0,10)$, sobre a degradabilidade potencial em 72 horas de incubação $(P>0,10)$ e sobre a taxa de degradação $(P>0,10)$ da FDN de forragem nativa de bom valor nutritivo (PB > 11\%), incubada no rúmen de novilhos em pastejo. Os valores de degradabilidade potencial obtidos foram de 53,6; 54,6 e 55,3\%; e as taxas de degradação foram de 3,3; 3,0 e $3,0 \% \mathrm{~h}^{-1}$ para os tratamentos controle (sem suplemento), suplemento energético e suplemento protéico, respectivamente.

Hess et al. (1996) estudaram o efeito do uso de fontes de fibra ou de amido sobre a degradabilidade potencial e a taxa de degradação da FDN do capim festuca contendo elevado valor nutritivo (\% PB $\geq 12 \%$ ). Constataram redução $(P=0,01)$ na taxa de degradação de $7,5 \% h^{-1}$ para 5,4 a $5,7 \% h^{-1}$ com a suplementação dos animais em pastejo, independente da fonte de carboidrato utilizado no suplemento. Entretanto, não houve efeito do tipo de suplemento (0,34\% do PV em milho moído contra $0,34 \%$ do PV em farelo de trigo) e da quantidade de suplemento utilizada $(0,34 \%$ vs $0,48 \%$ do $P V$ de farelo de trigo), sobre a taxa de degradação. A degradabilidade potencial obtida as 96 horas de incubação não apresentou diferença significativa $(P>0,10)$ entre os animais recebendo a dieta controle e os animais suplementados. Com isso, ressalta-se que o uso de suplemento reduziu $(P=0,02)$ a degradação da FDN nos tempos de 6,9 e 24 horas $(P<0,05)$ de incubação. Segundo os autores a lenta degradação, na fase inicial da incubação, levou à menor taxa de degradação da FDN $\left(\% \mathrm{~h}^{-1}\right)$. Mertens \& Loften (1980) estudaram o efeito do amido de milho e de trigo na digestão "in vitro" da fibra e sugeriram que o amido altera a digestão da fração fibrosa dos alimentos, principalmente por aumentar o "lag time".

A substituição da casca de soja por grão de milho em suplementos fornecidos na base de $40 \%$ da MS da dieta, não provocou redução na taxa (\% $\mathrm{h}^{-1}$ ) e nem na extensão da degradação da MS ( 96 horas) em feno de baixo valor nutritivo. Entretanto, quantidades crescentes de milho no suplemento oferecido, 
apresentaram efeito linear negativo sobre a degradabilidade da MS da forragem às 4 e 8 horas $(P<0,02)$ e às 12 horas $(P=0,07)$ de incubação (Grigsby et al. 1993).

Bodine et al. (2001) comparou o uso de suplemento protéico e dois tipos de fontes de energia (grãos contra uma mistura de farelo de trigo + casca de soja) para suplementar forragem de baixa qualidade (5,5\% de PB). Os autores não observaram efeito da suplementação e nem da origem de suplemento utilizado, sobre a degradabilidade potencial, após 72 horas de incubação da MS da forragem, apresentando valores de $63,83 \%$ para grãos e $68,05 \%$ para os não suplementados $(P>0,10)$. Entretanto, a suplementação elevou a taxa de degradação da MS da forragem de $1,92 \%$ para $2,88 \%$ a $3,35 \%$. O efeito positivo da suplementação nesse experimento ocorreu provavelmente, devido os suplementos elevarem o nível de proteína da dieta, já que o feno apresentava restrições qualitativas e os suplementos foram formulados para fornecer $1,1 \mathrm{~g}$ de PDR $\mathrm{kg}$ de $\mathrm{PV}^{-1}$. Lodman et al. (1990) também observaram efeito positivo da suplementação protéica sobre a taxa de degradação da MS e da FDN.

Pordomingo et al (1991) avaliaram niveis de suplementação, com milho laminado, sobre a degradação da matéria orgânica de forragem de elevado valor nutritivo consumida por novilhos em pastejo. Os autores observaram que o nivel mais baixo de suplementação ( $0,2 \%$ do PV) aumentou a degradação potencial da matéria orgânica da forragem, após 96 horas de incubação, quando comparada ao controle, enquanto que, níveis mais elevados de suplementação $(0,4$ e $0,6 \%$ do PV) deprimiram a degradação potencial da matéira orgânica. A taxa de degradação da matéria orgânica, observada para forragem incubada no rúmen de novilhos que receberam $0,2 \%$ do $P V$ de milho, apresentou apenas tendência de se elevar, quando comparada aos demais tratamentos. Há evidências de que efeitos associativos positivos podem ocorrer quando baixos níveis de carboidratos rapidamente fermentáveis no rúmen são adicionados em dietas com forragens de baixa a média qualidade, devido ao 
estímulo da digestão microbiana da forragem e síntese de proteína microbiana (Opatpatanakit et al. 1995).

Chase Junior \& Hibberd (1987) observaram redução linear na taxa de degradação da MS e da FDN do feno, com 4,2\% de PB, ao fornecerem 0, 1, 2 e $3 \mathrm{~kg}$ de milho moído por dia. Heldt et al. (1998) observaram redução na taxa de degradação $(P<0,01)$ e na degradabilidade potencial da $M S$, após 72 horas de incubação $(P=0,06)$ de feno de gramínea de baixo valor nutritivo, quando elevaram a quantidade de farelo de trigo na dieta dos animais. A mesma situação foi observada quando os autores avaliaram a degradabilidade da FDN do feno.

\subsection{Comportamento de pastejo}

A relação planta animal é um complexo sistema de interações quando os animais estão em contato direto com a forragem no campo (Erlinger et al. 1990). A estrutura e a composição botância da pastagem podem exercer um efeito direto sobre a ingestão de forragem por animais em pastejo, independentemente da influência da composição química e do conteúdo de nutrientes da própria forragem (Hodgson, 1990). Sempre que se abordam essas relações, entre a estrutura da pastagem e o comportamento de pastejo dos animais, questiona-se sobre a existência de informações em pastagens tropicais. Os trabalhos conduzidos por Stobbs (1973a) e Stobbs (1973b) indicaram que, em pastagens tropicais, a densidade volumétrica e a relação folha colmo ${ }^{-1}$ teriam importância mais relevante na determinação do comportamento ingestivo dos animais quando essas são comparadas com as pastagens temperadas.

A ingestão diária de forragem pelo animal em pastejo, é o produto do tempo gasto pelo animal pastejando e a taxa de ingestão dessa forragem durante o pastejo. A taxa de ingestão é obtida através do produto entre o número de bocados por minuto e a quantidade de forragem colhida por bocado 
(Hodgson, 1990; Cosgrove 1997). A resposta clássica desses parâmetros foi demonstrada por Penning (1986) citado por Carvalho et al. (2001). Ao mesmo tempo que se diminui a massa de forragem na pastagem, a quantidade de forragem apreendida a cada bocado também sofre redução, refletindo assim a condição da pastagem. Nessa situação, os animais aumentam o tempo de pastejo e a taxa de bocados. Apesar disso, o consumo diminui à medida que 0 menor tamanho do bocado não consegue ser compensado pelo aumento na frequência dos mesmos. Portanto, a massa por bocado é na maioria das vezes, o principal fator determinante da quantidade de alimento consumida por um animal em pastejo (Cosgrove 1997, Carvalho et al. 2001).

O comportamento de bovinos em pastejo foi avaliado por Krysl \& Hess (1993) por meio de uma extensa revisão, na qual foi detectada que os animais realizam de 65 a $100 \%$ de sua atividade em pastejo entre as 6 e as 19 horas do dia. Esses dados foram obtidos de experimentos realizados em ambientes com temperatura ambiental, regimes de suplementação, sistemas de pastejo e tipos de forragens muito variados. Ribeiro Filho et al. (1999) observaram também, que a maior atividade de pastejo dos animais, em pastagem de capim elefante anão (Pennisetum purpureum), se concentrou durante as 6 e 18 horas.

O tempo de pastejo é reflexo da facilidade de apreensão e remoção da forragem na pastagem (Crowder \& Chheda, 1982). Hodgson (1990) afirmou que o tempo de pastejo é muito variável e dependente da disponibilidade de forragem, podendo variar de 360 a 720 minutos dia $^{-1}$. Krysl \& Hess (1993) detectaram, que o tempo gasto para a atividade de pastejo variou de 359 a 711 minutos por dia.

Erlinger et al. (1990) observaram que novilhas de 4 grupos raciais, pastejando grama bermuda (Cynodon dactylon) sem suplementação, apresentaram tempos de pastejo que variaram de 348 a 515 minutos por dia. Stakelum et al. (1987) trabalhando com vacas leiteiras sob pastejo, com oferta de $30 \mathrm{~kg}$ de $\mathrm{MS}$ animal ${ }^{-1} \mathrm{dia}^{-1}$, observaram tempo de pastejo médio para esses

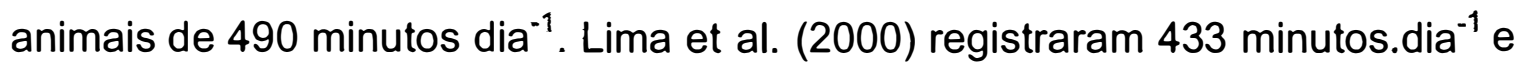


461 minutos $\mathrm{dia}^{-1}$ de atividade de pastejo para vacas leiteiras em sistema de pastejo rotacionado sobre capim Tanzânia (Panicum maximum) e capim Elefante (Pennisetum purpureum), respectivamente.

Ribeiro Filho et al. (1999) não observaram efeito de doses de nitrogênio, $0,250,500$ e $750 \mathrm{~kg} \mathrm{ha}^{-1}$, sobre o tempo de pastejo, quando a oferta de forragem foi de $9,17 \mathrm{~kg}$ de MS $100 \mathrm{~kg}_{\text {de }} \mathrm{PV}^{-1} \mathrm{dia}^{-1}$. O tempo de pastejo médio obtido por Ribeiro Filho et al. (1999) foi de 541 minutos dia ${ }^{-1}$.

Tempo de pastejo superior a faixa de 480 a 540 minutos dia $^{-1}$ indicará condições limitantes da pastagem (Hodgson, 1990). Dificilmente ovinos e bovinos ultrapassam o limite de 720 minutos dia $^{-1}$, em atividade de pastejo (Carvalho et al. 2001). Euclides et al. (1999) avaliaram o comportamento de pastejo de bovinos Nelore em pastagens de capim Tanzânia (Panicum maximum), Tobiatã (Panicum maximum) e Colonião (Panicum maximum) com disponibilidade média de MS de $2060 \mathrm{~kg} \mathrm{ha}^{-1}$ no verão, e $1610 \mathrm{~kg} \mathrm{ha}^{-1}$ na seca, e observaram aumento significativo $(P<0,05)$ do tempo de pastejo no inverno. Os tempos de pastejo observados nesse ensaio, foram de 511 minutos dia $^{-1}$ no verão e 596 minutos dia $^{-1}$ no inverno. Esses resultados demonstram que a redução na disponibilidade de forragem no período seco do ano determinou aumento no tempo de pastejo.

Cosgrove (1997) afirmou que a diminuição da disponibilidade de forragem provoca o aumento no tempo de pastejo, entretanto, em pastagens rasteiras, onde a apreensão de forragem é dificultada, os animais podem reduzir o tempo de pastejo. Isso foi observado por Chacon \& Stobbs (1976), que avaliaram o tempo de pastejo de vacas em pastagens de Setaria anceps cv. Kazungula, com diferentes disponibilidades de forragens, ao longo de nove dias de observação. Segundo esses autores, em pastagens sob lotação contínua, com alta pressão de pastejo, determinando disponibilidade de forragem limitada, a redução do tempo de pastejo explica-se pela relutância dos animais em selecionar pequena quantidade de folhas das hastes e das porções contaminadas por dejetos dos animais. Essa dificuldade foi mais intensa no 
período noturno com reduções mais acentuadas ainda no tempo de pastejo. Jamieson \& Hodgson (1979) sugeriram que em sistema de pastejo rotacionado, a redução no tempo de pastejo associado à baixa disponibilidade de forragem pode ser um reflexo condicionado, onde os animais ponderam a dificuldade de apreensão da forragem, com a antecipação de serem removidos a um novo piquete. Cosgrove (1997) mencionou que somente 4 a $32 \%$ das variações observadas no tempo de pastejo podem ser explicadas por fatores como a massa e altura da forragem, o número de folhas por unidade de área $\mathrm{e}$ digestibilidade da MS, havendo um grande componente comportamental inexplicado.

Além do tempo de pastejo, o animal se utiliza de 360 a 480 minutos dia $^{-1}$ para realizar a atividade de ruminação, e o tempo restante para descansar ou realizar outras atividades (Hodgson, 1990).

Adams (1985) testou o efeito de suplementação com 0,3 kg de milho por $100 \mathrm{~kg}$ PV e o momento da suplementação (manhã ou tarde) sobre o comportamento de pastejo de novilhos. Os resultados indicaram que o fato de suplementar os animais e o momento da suplementação não demonstraram diferença estatística sobre o tempo de pastejo, que variou de 438 a 540 minutos dia $^{-1}$, e também não afetou os tempos de ruminação e ócio observados, que foram de 420 e 873 minutos dia $^{-1}$, respectivamente.

Bonfim et al. (2000) não observaram efeito do nivel de concentrado ( $P$ > $0,05)$ sobre o tempo de pastejo de novilhos em forragem tropical, na estação seca do ano. Os niveis de concentrado utilizados foram, 0,6; 0,9; 1,2 e 1,5\% do PV dos animais, e os tempos de pastejo obtidos foram 386,$25 ; 366,00 ; 346,25$ e 315,00 minutos dia $^{-1}$, respectivamente.

No entanto Krysl \& Hess (1993) avaliando a influência da suplementação no tempo de pastejo, constataram redução no tempo de pastejo com o aumentando do nivel de suplementação com grãos (amido).

Difante et al. (2001) observaram efeito significativo do nivel de suplemento sobre os tempos de pastejo, de ruminação e em ócio, de bezerros 
pastejando azevém (Lolium multiflorum) adubado com nitrogênio. O uso 0,8\% do PV em milho moído apresentou diferença significativa $(P<0,0001)$ sobre os tratamentos controle (sem suplemento), e oferta de $0,4 \%$ do PV em milho moído $(P=0,042)$. Entretanto, não houve diferença estatística entre o tratamento controle e o menor nível de suplementação $(P=0,104)$. Os tempos de pastejo registrados foram de 419, 391 e 334 minutos dia $^{-1}$; os tempos de ruminação foram de 514,471 e 461 minutos.dia $^{-1}$; e os tempos em ócio foram de 507, 555 e 612 minutos.dia ${ }^{-1}$; para os tratamentos sem suplemento, e os suplementados com 0,4 e $0,8 \%$ do PV em milho moído, respectivamente.

A origem do suplemento para pastagens com disponibilidade de matéria seca dentro da amplitude de $3654 \mathrm{~kg} \mathrm{ha}^{-1}$ a $4353 \mathrm{~kg} \mathrm{ha}^{-1}$ foi avaliado por Bodine et al. (2000b). Esses autores forneceram 1,3\% do PV do animal em milho moído ou milho moído + farelo de soja, e $0,4 \%$ do PV do animal em farelo de soja, além de um tratamento controle sem suplemento. Foram observadas reduções no tempo de pastejo dos animais quando os suplementos continham milho, comparado aos tratamentos que apresentaram exclusivamente farelo de soja $(0,4 \%$ do $P V)$ e o controle. Os tempos de pastejo observados foram de 407, 421, 490 e 493 minutos dia $^{-1}$, para os tratamentos com 1,3\% do PV em milho + farelo de soja, $1,3 \%$ do PV em milho, $0,4 \%$ do PV em farelo de soja e o controle, respectivamente.

Gekara et al. (2001) avaliaram a altura do dossel e o uso de suplementos sobre o tempo de pastejo de vacas de corte em pastagens temperadas. As alturas avaliadas foram de 4 a $8 \mathrm{~cm}$ e 8 a $11 \mathrm{~cm}$, que

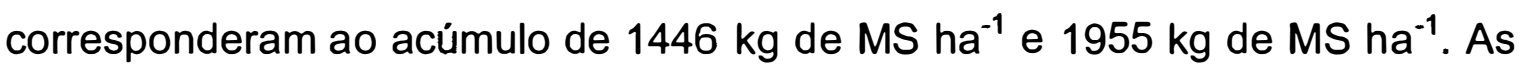
quantidades de suplementos fornecidos foram 0; 3,2 e 6,4 $\mathrm{kg} \mathrm{dia}^{-1}$. Os autores não observaram interação entre as quantidades de suplementos e as alturas do dossel avaliadas $(P>0,10)$. Entretanto, a redução na altura do dossel elevou ( $P$ $<0,01$ ) o tempo de pastejo em 72 minutos dia ${ }^{-1}$ (564 contra 492 minutos dia ${ }^{-1}$ ). A média do tempo de pastejo demonstrado pelos animais suplementados não diferiu do grupo controle $(p=0,1115)$. Entretanto, houve uma tendência de 
redução no tempo de pastejo dos animais que receberam $6,4 \mathrm{~kg} \mathrm{dia}^{-1}$ de suplemento, comparado ao grupo suplementado com $3,2 \mathrm{~kg} \mathrm{dia}^{-1}(P=0,0528)$. Os tempos de pastejo observados entre os niveis de suplementação foram de 546, 540 e 498 minutos $\mathrm{dia}^{-1}$, para $0 ; 3,2$ e 6,4 $\mathrm{kg}$ de suplemento $\mathrm{dia}^{-1}$, respectivamente.

A forma de fornecimento do suplemento (fornecimento diário sem limitante de consumo contra uso de sal como limitante de consumo) não demonstrou efeito significativo $(P>0,05)$ sobre o tempo de pastejo (Brandberry et al. 1991). Esses autores observaram ainda que os animais concentraram a atividade de pastejo das 6 as 9 horas, no periodo da manhã, e entre 15 e 18 horas, no periodo da tarde.

Soriano et al. (2000) avaliaram o efeito do fornecimento de $6 \mathrm{~kg} \mathrm{dia}^{-1} \mathrm{de}$ milho ensilado com alta umidade ou milho moido grosso para vacas leiteiras. Não observaram efeito do tipo de suplemento sobre o tempo de pastejo apresentado pelos animais que foi de 384 minutos dia ${ }^{-1}$. Entretanto, os autores observaram que os animais apresentaram dois picos distintos de atividade de pastejo, um ao amanhecer das 7:30 as 9:00 horas, e outro das 15:30 as 20:30 horas.

Dessa forma, procurou-se avaliar o potencial do uso de suplementos energéticos com niveis diferentes de disponibilidade do amido no rúmen e o uso da suplementação protéica sobre o consumo, digestibilidade, parâmetros ruminais e comportamento de pastejo de bovinos, manejados em pastagens rotacionadas sob duas disponibilidades de matéria seca verde, para distinguir qual fator seria determinante (suplemento ou disponibilidade de forragem) do desempenho de animais manejados sob estas condições, no verão. Além disso os suplementos energéticos oferecidos, procuraram fornecer nutrientes para atingir-se 1,2 a $1,3 \mathrm{~kg}$ de ganho de peso vivo por dia, de acordo com a expectativa de disponibilidade da fração nitrogenada proveniente da forragem consumida (NRC, 1996), enquanto o tratamento utilizando-se de farelo de soja, simulou a amplificação da síntese de proteína microbiana. 


\section{CONSUMO, PARÂMETROS RUMINAIS E DIGESTIBILIDADE DE NUTRIENTES EM DE BOVINOS DE CORTE MANEJADOS SOB PASTEJO ROTACIONADO EM CAPIM TANZÂNIA (Panicum maximum Jacq. cv. Tanzânia) E SUPLEMENTADOS COM ENERGIA OU PROTEÍNA, DURANTE O VERÃO.}

\section{Resumo}

Oito garrotes da raça Nelore foram utilizados em um sistema de pastejo rotacionado, em capim Tanzânia, sob dois níveis de resíduo de MS verde (MSV) obtidos após a saída dos animais $\left(\mathrm{R} 1=1000 \mathrm{~kg} \mathrm{ha}^{-1}\right.$ de MSV e R2 = $4000 \mathrm{~kg} \mathrm{ha}^{-1} \mathrm{de} \mathrm{MSV).} \mathrm{Quatro} \mathrm{garrotes} \mathrm{foram} \mathrm{alocados} \mathrm{a} \mathrm{cada} \mathrm{um} \mathrm{dos} \mathrm{resíduos,}$ sendo distribuídos em dois quadrados latinos $4 \times 4$, onde cada animal recebeu um tratamento de suplementação ( $S 0=$ sem suplementação; $S 1=2,24 \mathrm{~kg} \mathrm{dia}^{-1}$ de milho moído grosso; $\mathrm{S} 2=2,24 \mathrm{~kg} \mathrm{dia}^{-1}$ de milho floculado; $\mathrm{S} 3=0,7 \mathrm{~kg} \mathrm{dia}^{-1}$ de farelo de soja). Os ciclos de pastejo se constituiram em 33 dias como período de descanso e 3 dias de ocupação. Houve aumento de consumo ( $P<$ $0,05)$ de matéria seca da forragem com o aumento na disponibilidade de MSV e aumento de consumo de matéria seca total e de matéria orgânica total, com a suplementação $(P<0,05)$. A suplementação reduziu o $\mathrm{pH}$ ruminal, a relação acético:propiônico e elevou a concentração molar de ácido propiônico no fluido rumimal $(P<0,05)$. Animais manejados no menor resíduo de MSV pós pastejo, apresentaram maior concentração total de ácidos graxos voláteis $(P<0,05)$. Não observou-se efeitos significativos da disponibilidade de forragem sobre a digestibilidade dos nutrientes $(P>0,05)$, à exceção da $P B$. $O$ uso de milho 
moído grosso elevou a digestibilidade da porção fibra $(P<0,05)$. A suplementação e a disponibilidade de forragem não alteraram o NDT $(P>0,05)$.

Palavras chave: bovinos, suplementação, consumo, fermentação ruminal, digestiblidade.

\section{INTAKE, RUMINAL PARAMETERS AND NUTRIENT DIGESTIBILITY IN BEEF CATTLE ROTATIONALLY GRAZING TANZANIA GRASS, SUPPLEMENTED WITH ENERGY OR PROTEIN DURING SUMMER}

\section{Summary}

Eight Nelore steers were used in a Tanzania grass rotational grazing system under two post grazing green dry matter (GDM) residue (1000 and 4000 $\mathrm{kg} \mathrm{ha}^{-1}$ ), three days of grazing period and 33 days of resting period. Four animals were allocated to each one of the post grazing residue. Four sources of supplements (WO - no supplement; CC -2.24 kg day ${ }^{-1}$ cracked corn; SFC - 2.24 $\mathrm{kg} \mathrm{day}^{-1}$ steam flaked corn and SBM $-0,7 \mathrm{~kg} \mathrm{day}^{-1}$ soybean meal) were used in a Latin square design. Forage dry matter intake was higher $(P<.05)$ for the highest post grazing residue. Total dry and organic matter intakes were higher $(\mathrm{P}<.05)$ in the supplemented animals. Rumen $\mathrm{pH}$ and the acetic:propionic ratio decreased and propionic acid increased with supplementation $(P<.05)$. Total rumen volatile fatty acids was higher in animals kept in the low post grazing residue. All nutrient digestibilities but protein were unaffected by the post grazing residue. The FDN digestibility was higher $(P<.05)$ in $C C$ supplemented animals. The estimated TDN was unaffected by both supplements and forage availability. 
Key words: bovine, supplements, intake, ruminal fermentation, digestibility

\subsection{Introdução}

A produção de bovinos de corte realizada em paises tropicais pode atingir niveis de produtividade expressivos, devido ao alto potencial de produção de matéria seca das pastagens. As plantas forrageiras são as responsáveis por toda a oferta de energia, proteína, vitaminas e parte dos elementos minerais necessários ao atendimento das exigências de manutenção e produção dos animais.

No entanto o desempenho de bovinos em pastejo ainda pode ser considerado aquém de seu potencial, em função das características nutricionais que a planta forrageira impõe: alto teor de fibra e uma grande proporção do nitrogênio apresentando-se sob forma solúvel, principalmente quando a pastagem é manejada intensivamente com uitilização de altas doses de fertilizantes nitrogenados (Poppi \& McLennan, 1995).

O excesso de nitrogênio solúvel aliado ao déficit de carboidratos não estruturais encontrados na composição química dessas gramíneas, induzem a um excesso de amônia, insatisfatóriamente acoplado à disponibilidade de energia fermentável para a produção de proteína microbiana no rúmen (Poppi \& McLennan, 1995, Boin et al. 1997). A suplementação com fontes de ingredientes concentrados energéticos, pode otimizar sobremaneira os processos fermentativos no rúmen, fornecendo energia fermentável, que juntamente com o nitrogênio amoniacal presente no local, aumenta a eficiência da sintese de proteína de origem microbiana (Karges et al. 1992; Poppi \& McLennan, 1995).

Leng (1990) definiu para condições tropicais que a concentração mínima de amônia no fluido ruminal seria de $10 \mathrm{mg} \mathrm{dL}^{-1}$, acima dos valores clássicos 
definidos por Satter \& Slyter (1974) entre 2 e $5 \mathrm{mg} \cdot \mathrm{dL}^{-1}$, como mínimos para não restringir a digestão da matéria orgânica da dieta no rúmen.

O uso de suplementos energéticos para animais pastejando gramíneas, apresenta efeitos conflitantes em relação ao nível de amônia ruminal. Jones et al. (1988) não observaram efeito da suplementação com $0,3 \%$ de milho sobre o nivel de amônia ruminal de animais consumindo Cynodon dactylon, enquanto Brake et al. (1989) observaram redução da concentração de amônia ruminal com a utilização de milho (0,60\% PV) não observando o mesmo efeito para o fornecimento de cevada (0,64\% PV). Hess et al. (1996) observaram que a utilização de suplementos energéticos à base de milho ou farelo de trigo elevou as concentrações médias de amônia ruminal de animais pastejando gramínea temperada. A explicação para este fenômeno seria a contribuição do nitrogênio contido no suplemento energético, que juntamente ao nitrogênio contido na dieta elevariam o consumo total de nitrogênio pelos animais (Obara et al. 1991).

Detmann et al. (2001) observaram maiores concentrações de amônia no fluido ruminal, de 2 a 6 horas após a suplementação, quando maiores niveis de suplementos contendo farelo de soja foram utilizados, demonstrando o efeito de fontes de proteína de alta degradabilidade ruminal sobre a produção de amônia ruminal.

Entretanto o uso de suplementos poderá exercer influência sobre a cinética da degradação da parede celular presente na matéria seca da pastagem, devido a reduções no $\mathrm{pH}$ ruminal (Chase Jr \& Hibberd, 1987, Hess et al. 1996, Caton \& Dhuyvetter, 1997). Dixon \& Stockdale (1999) afirmaram que $\circ \mathrm{pH}$ deve manter-se entre 6,6 a 7,0 para garantir fermentação adequada da parede celular. Segundo esses autores a digestão da fibra é intensamente reduzida quando o $\mathrm{pH}$ do fluido ruminal situar-se entre 6,0 e 6,2, e desprezivel quando o $\mathrm{pH}$ ruminal for infeirior a 6,0 .

Desta forma, a utilização de suplementos energéticos, poderá provocar um efeito substitutivo limitando a ingestão de forragem (Paterson et al. 1994), 
além de atuar sobre o comportamento de pastejo (Krysl \& Hess, 1993). O efeito de substituição pode ser alterado em função da quantidade de suplemento energético fornecido aos animais (Hodgson, 1990, Caton \& Dhuyvetter, 1997). Quantidades mais elevadas de suplemento podem deprimir o consumo de forragem apresentando coeficientes de substituição próximos a 1 ou maiores que 1 (Minson, 1990), enquanto pequenas quantidades de concentrados adicionados ou não de fontes de proteína, podem elevar o consumo de forragem (Hodgson, 1990, Dixon \& Stockdale, 1999). Minson (1990) e Paterson et al. (1994) realizaram extensas revisões de literatura e observaram um coeficiente de substituição médio de 0,69.

Pordomingo et al. (1991) observaram que o nível de suplementação de $0,2 \%$ do PV em milho estimulou o consumo de matéria seca da pastagem, enquanto níveis de $0,4 \%$ e $0,6 \%$ do peso vivo causaram efeito de substituição para forragem de elevado valor nutritivo, contendo entre 9,3 e $11,6 \%$ de PB na matéria seca. Outro fator a ser considerado é o valor nutritivo da planta forrageira. Minson (1990) e Paterson et al. (1994) observaram maior efeito de substituição para plantas forrageiras de melhor qualidade.

O consumo de matéria seca da forragem demonstra-se muito variável dependendo da estrutura da pastagem e da qualidade da planta forrageira (Poppi et al. 1987). Caton \& Dhuyvetter (1997) observaram que a ingestão de matéria seca da pastagem, por bovinos, variou entre $0,91 \%$ e $4,30 \%$ do peso vivo. Trabalhos realizados no Brasil com plantas forrageiras tropicais apontam para consumos de matéria seca da forragem variando entre $1,82 \%$ a $2,51 \%$ do peso vivo para bovinos de corte estabulados (Thiago et al. 1991) e em pastejo (Euclides et al. 1999, Detmann et al. 2001). Consumos mais elevados variando entre 2,5 a $3,7 \%$ do peso vivo foram registrados por Ribeiro et al. (1997), quando a oferta de lâmina foliar foi elevada de 4 para $16 \mathrm{~kg}$ de matéria seca de lâmina foliar. $100 \mathrm{~kg} \mathrm{PV}^{-1}$.

Conrad et al. (1964) e Mertens (1994), estabeleceram que o consumo de 
matéria por um animal é limitado por processos físicos e ou fisiológicos. $O$ controle físico depende do nível de parede celular na dieta, e atua quando a digestibilidade da matéria seca for inferior a $66 \%$. O controle fisiológico é regulado por produtos da fermentação ruminal, principalmente a produção de ácido propiônico, quando a digestibilidade for superiror a 66\% (Thiago \& Gill, 1990, Forbes, 1995).

Desta forma, o nível e a digestibilidade do FDN, assim como a produção de ácido propiônico decorrente do tipo de dieta fornecido para os animais, apresentam grande importância na explicação do consumo e, consequentemente, do desempenho animal, quando a estrutura da pastagem não estiver limitando a apreensão da planta forrageira.

O uso de suplementos energéticos podem reduzir a digestão de fibra no rúmen, e consequentemente, no trato total, se o intestino grosso não compensar a redução na digestibilidade ruminal (Hoover 1986). Detmann et al. (2001) não observaram efeito do tipo e do nível de concentrados utilizados como suplemento, sobre a digestibilidade aparente da MS e do FDN da dieta de animais pastejando Brachiaria decumbens. Resultados semelhantes foram observados por Mathis et al. (2000) que não encontraram efeito do nível de proteína degradável no rúmen (PDR), sobre a digestibilidade aparente da matéria orgânica e da FDN. Krysl et al. (1989) compararam o uso de suplementos energético e protéico, e não observaram efeito do tipo de suplemento sobre a digestibilidade aparente do FDN e do FDA, enquanto a digestibilidade aparente da matéria orgânica foi elevada com a suplementação, sem diferença significativa entre o farelo de soja e o sorgo floculado. Entretanto Hoover (1986), em extensa revisão de literatura, observou que a adição de carboidratos rapidamente fermentáveis à dietas com forragem, reduziu a digestão de fibra em experimentos "in vivo" e "in vitro".

O aumento na ingestão e na degradação do amido no rúmen causa um aumento na produção total de ácidos graxos voláteis (AGV's) de acordo com 
Simas (1995) e Chen (1994). A floculação aumentou a produção de AGV's totais, ácido propiônico e reduziu a relação acético:propiônico no fluido ruminal de vacas leiteiras consumindo capim-elefante colhido sob pastejo simulado, picado e fornecido no cocho, e suplementado com milho floculado ou milho moído grosso (Lima 2000).

Experimentos realizados com animais em pastejo ou recebendo feno de gramineas, demonstram efeito positivo do uso de concentrados sobre a produção de AGV's, com redução na relação acético:propiônico, causada pela depressão na concentração de ácido acético e/ou elevação na concentração de ácido propiônico no fluido ruminal (Vanzant et al. 1990, Galloway et al. 1993, Hess et al. 1996, Elizalde et al. 1999, Olson et al. 1999). Entretanto o uso de suplementos não alterou a produção e a relação de ácidos graxos voláteis em outras avaliações (Chase \& Hibberd, 1987, Krysl et al. 1989, Pordomingo et al. 1991, Soriano et al. 2000). Bodine et al. (2001) comparou o uso de fontes de energia com farelo de soja como suplementos para animais em pastejo e apenas registrou efeito das fontes de energia sobre a fermentação ruminal.

O objetivo deste trabalho foi o de avaliar o efeito da suplementação energética ou protéica, sobre o consumo, parâmetros ruminais e a digestibilidade aparente das porções fibra e amido da dieta de bovinos de corte em recria mantidos em pastagens manejadas intensivamente, durante 0 período do verão.

\subsection{Material e métodos}

\subsubsection{Instalações experimentais e animais}

O experimento foi realizado na fazenda Areão da ESALQ/USP em uma área de 6 hectares estabelecida com capim Tanzânia (Panicum maximum Jacq. Cv. Tanzania) sob irrigação com equipamento do tipo pivô central, subdividida 
em quatro blocos. Cada bloco foi composto por um conjunto de seis piquetes, com três piquetes para cada resíduo de pastejo, perfazendo um total de 24 subdivisões, com $1500 \mathrm{~m}^{2}$ cada, divididas por cercas fixas e/ou eletrificadas. Cada resíduo de pastejo testado foi dividido em 12 piquetes. O manejo adotado para o sistema constitui-se em um intervalo de descanso de 33 dias, com três dias de ocupação para cada piquete. A forragem recebeu fertilização na dose de $334 \mathrm{~kg} \mathrm{ha}^{-1}$ da fórmula 24-04-24 (80 kg de $\mathrm{N} \mathrm{ha}^{-1}$ ) para cada ciclo de pastejo, logo após a saída dos animais.

Foram utilizados oito garrotes da raça Nelore, com peso vivo médio de $306,6 \mathrm{~kg}$, divididos em dois grupos de quatro animais cada, em um delineamento experimental contendo dois quadrados latinos $4 \times 4$, um para cada resíduo de pastejo estudado. Em cada quadrado latino foram testados quatro formas de suplementação. Os animais utilizados neste experimento sofreram adaptação prévia às instalações e à cirurgia de implantação das cânulas no rúmen e no duodeno proximal.

\subsubsection{Tratamentos}

Um grupo de quatro animais permaneceu durante o periodo experimental em doze piquetes rotacionados, manejados para atingirem resíduo pós pastejo de $1000 \mathrm{~kg}$ de matéria seca verde ha-1 (R1), enquanto o outro grupo de quatro animais permaneceu em doze piquetes rotacionados, manejados com o objetivo de atingir $4000 \mathrm{~kg}$ de matéria seca verde ha ${ }^{-1}(\mathrm{R} 2)$, de resíduo pós pastejo (Penati, 2002). Os quatro animais utilizados em cada tratamento de resíduo pós pastejo, foram mantidos juntamente com outros animais chamados de traçadores, que entravam e saiam dos piquetes, com o objetivo de obter-se os resíduos pós pastejo desejados. A cada intervalo de 33 dias os animais retornavam ao piquete inicial do sistema.

Em cada resíduo pós pastejo haviam quatro tratamentos de 
suplementação:

S0 - Controle, sem suplementação (SS)

$\mathrm{S} 1$ - 2,24 $\mathrm{kg} \mathrm{dia}^{-1}$ de milho moído grosso em peneira de $8 \mathrm{~mm}$ (MMG)

$\mathrm{S} 2$ - 2,24 $\mathrm{kg} \mathrm{dia}^{-1}$ de milho floculado $\left(360 \mathrm{~g} . \mathrm{L}^{-1}\right)(\mathrm{MF})$

S3 $-0,8 \mathrm{~kg} \mathrm{dia}^{-1}$ de farelo de soja (FS)

O milho floculado preparado pela Cia Sul Mineira, Varginha-MG, se submeteu aos ajustes de equipamento visando intensidade de processamento físico necessário para obter-se densidade final de $360 \mathrm{~g} \mathrm{~L}^{-1}$.

As quantidades de suplementos energéticos ofertadas foram compativeis com a expectativa de disponibilidade da fração nitrogenada proveniente da pastagem, para garantir um desempenho estimado de ganho ao redor de $1,2 \mathrm{~kg}$ $\mathrm{dia}^{-1}$ e 1,3 $\mathrm{kg} \mathrm{dia}^{-1}$ respectivamente, para os tratamentos S1 e S2 (NRC, 1996). No caso do tratamento $\mathrm{S} 4$, a oferta adicional de farelo de soja, simulou a possibilidade de amplificação da síntese de proteína microbiana, com a elevação da disponibilidade de uma fonte de proteína de maior taxa de degradação ruminal, atingindo níveis mais elevados de proteína dietética e amônia ruminal.

Os suplementos foram fornecidos duas vezes ao dia em quantidades iguais ( $50 \%$ do total pela manhã e $50 \%$ à tarde), em torno das 7 e 16 horas, através da cânula ruminal para garantir que toda a quantidade de suplemento fosse ingerida. Os animais tinham livre acesso a misturas minerais colocadas em cochos próprios disponíveis em cada piquete de pastejo.

\subsubsection{Período experimental}

Um período pré-experimental de 5 meses, foi necessário para amansar os animais e realizar as cirurgias, e a completa recuperação dos animais no 
período pós cirúrgico.

O período experimental teve duração de 50 dias, iniciando no dia 05/12/1999 e encerrando dia 24/01/2000. Este período foi subdividido em 4 subperíodos, de 12 a 13 dias de extensão, com 8 a 9 dias de adaptação e 4 dias de coleta de conteúdo ruminal. A variação no período de adaptação ocorreu em função das condições metereológicas que permitissem o manejo dos animais.

\subsubsection{Consumo de matéria seca da pastagem}

O consumo de matéria seca da pastagem foi estimado através da equação desenvolvida por Orskov et al. (1988), utilizando-se como variáveis a degradação potencial da MS e a taxa de degradação da MS da forragem, conforme representação a seguir:

IMS $=-0,822+0,0748(a+b)+40,7 c$

Sendo:

IMS = ingestão de matéria seca, $\mathrm{kg} \mathrm{dia}^{-1}$

$a+b=$ degradação potencial da matéria seca, $\%$

$\mathrm{c}=$ taxa de degradação da matéria seca, $\% \mathrm{~h}^{-1}$

As médias estimadas pela equação para o consumo de MS e MO para os tratamentos controle no presente experimento, assemelham-se às observadas por Balsalobre (2002) que utilizou óxido de cromo como marcador externo, para estimativa de consumo exclusivo de pastagem por animais submetidos aos mesmos resíduos pós pastejo.

Aos valores obtidos foram adiconadas as quantidades ( $\mathrm{kg} \mathrm{de} \mathrm{MS} \mathrm{dia}^{-1}$ ) de concentrado fornecidas aos animais, para ser calculada a ingestão total de 
matéria seca por animal diariamente.

O coeficiente de substituição observado para os suplementos utilizados foi calculado em relação ao SO (controle) utilzando-se a seguinte fórmula:

$\mathrm{CS}=\mathrm{RIMSP} / \mathrm{IMSC}$

Sendo:

CS = coeficiente de substituição,

RIMSP = redução na ingestão de matéria seca da pastagem, $\mathrm{kg} \mathrm{dia}^{-1}$

IMSC = ingestão de matéria seca do concentrado, $\mathrm{kg} \mathrm{dia}^{-1}$

\subsubsection{Coleta de conteúdo ruminal e determinação do pH, ácidos graxos voláteis e nitrogênio amoniacal}

As amostras de conteúdo ruminal foram coletadas do nono ao décimo segundo dia ou do décimo ao décimo terceiro dia do subperíodo dependendo da extensão do subperíodo, sob intervalos de 8 horas, escalonadas no tempo com defasagem de duas horas $\mathrm{dia}^{-1}$, totalizando doze horários de coleta ao longo do subperíodo. Os tempos de coleta foram estabelecidos nos horários 0 , $2,4,6,8,10,12,14,16,18,20$ e 22 horas. As coletas foram realizadas em quatro pontos distintos do rúmen, após prévia homogeneização do conteúdo no interior do rúmen, filtradas em quatro camadas de tecido de algodão (pano de fralda), obtendo-se dessa forma, aproximadamente $200 \mathrm{~mL}$ de fluido ruminal filtrado, no qual foi determinado imediatamente o $\mathrm{pH}$ das amostras, através de leitura direta com potenciômetro digital (Digimed TE-902).

Após a determinação do $\mathrm{pH}$, foram retiradas duas alíquotas de $30 \mathrm{~mL}$ do fluido ruminal que foram congeladas $a-10^{\circ} \mathrm{C}$, para posterior determinação de nitrogênio amoniacal $\left(\mathrm{N}-\mathrm{NH}_{3}\right)$, e ácidos graxos voláteis (AGV). Após o descongelamento, uma das alíquotas foi centrifugada a $12.000 \mathrm{~g} \mathrm{a} 4^{\circ} \mathrm{C}$, durante 
20 minutos, sendo uma fração do sobrenadante utilizada para a determinação de $\mathrm{N}-\mathrm{NH}_{3}$ de acordo com o método colorimétrico descrito por Chaney \& Marbach (1962) e adaptado para ser utilizado em placas de microtítulo e posterior leitura em aparelho do tipo Elisa Reader (absorbância de 550 nanômetros).

Da outra alíquota foram coletados $8 \mathrm{~mL}$ e misturados a $2 \mathrm{~mL}$ de ácido metafosfórico $25 \%$. Esta mistura foi centrifugada a $12.000 \mathrm{~g}$ a $4^{\circ} \mathrm{C}$, durante 20 minutos, e uma fração do sobrenadante foi utilizada para determinação de AGV's de acordo com Palmquist \& Conrad (1971), utilizando cromatógrafo líquido gasoso, CLG (Hewlett Packard 5890, Series II), equipado com HP Integrator (Hewlett Packard Company, Avondale, PA). O padrão interno utilizado foi ácido 2-etilbutírico e o nitrogênio foi o gás de arraste. A temperatura do injetor, detector e coluna, foram 150, 190 e $115^{\circ} \mathrm{C}$, respectivamente. Em cada tubo de leitura em cromatógrafo foram colocados, $100 \mu \mathrm{L}$ do padrão, $1000 \mu \mathrm{L}$ do sobrenadante após a centrifugação, que foi composto por $800 \mu \mathrm{L}$ de fluído ruminal e $200 \mu \mathrm{L}$ de ácido metafosfórico.

\subsubsection{Coleta de amostras dos alimentos e análises bromatológicas nos alimentos e nas fezes}

As amostras de forragem foram coletadas diariamente, durante os quatro dias de coleta dos períodos, simulando o pastejo dos animais, com amostras sendo separadas por dia de coleta e por resíduo pós pastejo (R1 e R2), totalizando oito amostras por período de coleta. Logo após a realização do pastejo simulado, as amostras de forragem foram secas em estufa de ventilação forçada a $60^{\circ} \mathrm{C}$ por 72 horas.

As amostras dos concentrados foram coletadas diariamente, durante os quatro dias de coleta, de cada período experimental, totalizando quatro subamostras, que posteriormente foram homogeneizadas, formando uma amostra 
composta por período.

As fezes foram coletadas a cada oito horas, durante os quatro dias de coleta. As porções coletadas em cada horário eram conservadas sob refrigeração e no final do período eram homogeneizadas e secas em estufas de ventilação forçada $a 0^{\circ} \mathrm{C}$ por 72 horas.

Todas as amostras de alimentos e fezes sofreram moagem em moinho tipo Willey com peneira de $1 \mathrm{~mm}$, após a secagem. As análises de matéria seca, matéria mineral e extrato etéreo foram conduzidas em duplicatas conforme metodologia descrita pelo AOAC (1980). A determinação da proteína bruta foi realizada em duplicata, através da combustão total do nitrogênio da amostra, seguindo o método de Dumas e utilizando o equipamento Leco ${ }^{\circledR}$, modelo FP. 528, validado por Wiles et al. (1998). A determinação do extrato etéreo nas fezes foi conduzida utilizando como solvente éter de petróleo acidificado com ácido acético glacial $5 \%$.

As frações fibra em detergente ácido e fibra em detergente neutro das amostras, foram determinadas em duplicata, de forma sequencial, conforme metodologia descrita por Van Soest et al. (1991), utilizando-se do equipamento Fiber Analyser Ankom 200 (Holden 1999). A lignina foi determinada através do método LDA (lignina em detergente ácido) com uso de solução ácido sulfúrico $72 \%$ (Van Soest et al. 1991), em sequência à fibra em detergente ácido, utilizando o equipamento Daisy Incubator Ankon (Holden 1999).

A determinação do nitrogênio retido na fibra em detergente ácido ( $\mathrm{N}$ FDA) foi executada com $1 \mathrm{~g}$ de amostra (Goering \& Van Soest, 1970), após a recuperação da fração fibra em detergente ácido no Fiber Analyser Ankom 200 (Holden 1999), em equipamento Macro Kjeldahl conforme Krishnamoorthy et al. (1983). A determinação do amido foi realizada em triplicata, através da técnica descrita por Poore et al. (1989).

O cálculo da fração carboidratos não fibrosos (CNF), como porcentagem da matéria seca, foi obtido através da fórmula: 
$C N F(\%)=100-(P B+F D N+E E+M M)$

Onde:

$\mathrm{PB}=$ porcentagem de proteína bruta na matéria seca,

FDN = porcentagem da fibra detergente neutro na matéria seca,

$E E=$ porcentagem de extrato etéreo na matéria seca,

$\mathrm{MM}=$ porcentagem de matéria mineral na matéria seca,

A composição bromatológica da forragem colhida simulando o pastejo dos animais, nos quatro períodos experimentais, apresenta-se na Tabela 1. A composição dos alimentos utilizados como suplementos encontram-se na Tabela 2.

Tabela 1. Composição bromatológica expressa em \% da matéria orgânica (MO) e a $\%$ de matéria mineral da forragem colhida, simulando o pastejo dos animais, nos resíduos pós pastejo (RPP) R1 e R2 nos quatro períodos experimentais.

\begin{tabular}{lccccccc}
\hline \multirow{2}{*}{ Periodo } & \multirow{2}{*}{ RPP } & \multicolumn{7}{c}{ Frações (\%) } \\
\cline { 3 - 7 } & & PB & CNF $^{\mathrm{a}}$ & FDN & FDA & EE & MM \\
\hline P1 & R1 $^{\text {b }}$ & 12,10 & 14,86 & 72,04 & 39,87 & 0,99 & 16,30 \\
& R2 & 19,11 & 9,57 & 70,16 & 36,11 & 1,16 & 10,43 \\
P2 & R1 & 13,53 & 7,56 & 77,78 & 43,39 & 1,13 & 13,45 \\
& R2 & 13,70 & 8,58 & 76,37 & 41,66 & 1,35 & 10,83 \\
P3 & R1 & 14,70 & 9,18 & 74,77 & 42,24 & 1,35 & 17,51 \\
& R2 & 12,99 & 8,42 & 77,36 & 43,07 & 1,24 & 10,52 \\
P4 & R1 & 10,41 & 9,69 & 78,63 & 41,29 & 1,27 & 8,57 \\
& R2 & 14,35 & 7,94 & 76,40 & 40,69 & 1,31 & 10,81 \\
\hline
\end{tabular}

${ }^{a} \mathrm{CNF}=$ carboidratos não fibrosos

${ }^{\mathrm{b}} \mathrm{R} 1=1000 \mathrm{~kg} \mathrm{~h}^{-1}$ de matéria seca verde, $\mathrm{R} 2=4000 \mathrm{~kg} \mathrm{~h}^{-1}$ de matéria seca verde 
Optou-se pela apresentação das médias nas tabelas 1 e 2 com base na matéria orgânica, uma vez que a elevada contaminação por solo nas amostras de pastejo simulado, especialmente em R1, determinaram distorções na interpretação dos resultados relativos ao consumo e digestibilidade dos nutrientes.

Tabela 2. Composição bromatológica expressa em \% da matéria orgânica (MO) e a \% de matéria mineral dos ingredientes milho moído grosso (MMG), milho floculado (MF) e farelo de soja (FS) utilizados com suplementos nos quatro períodos experimentais.

Período Alimentos Frações (\%)

\begin{tabular}{ccccccccc} 
& & PB & CNF $^{\mathrm{a}}$ & FDN & FDA & Amido & EE & MM \\
\hline \multirow{3}{*}{ P1 } & MMG & 9,50 & 72,86 & 14,26 & 3,01 & 70,01 & 3,38 & 1,15 \\
& MF & 9,39 & 76,72 & 9,99 & 2,94 & 70,41 & 3,90 & 1,60 \\
& FS & 57,04 & 28,34 & 13,32 & 9,49 & 0 & 1,30 & 5,93 \\
P2 & MMG & 9,21 & 76,75 & 10,68 & 2,78 & 68,17 & 3,86 & 0,99 \\
& MF & 9,36 & 76,97 & 10,15 & 2,67 & 71,12 & 3,52 & 0,96 \\
& FS & 56,78 & 27,65 & 14,30 & 10,90 & 0 & 1,28 & 6,07 \\
& & & & & & & & \\
P3 & MMG & 9,21 & 75,36 & 11,30 & 2,76 & 65,87 & 4,17 & 1,22 \\
& MF & 9,24 & 75,30 & 11,13 & 2,95 & 61,63 & 4,32 & 1,24 \\
& FS & 55,59 & 29,11 & 13,69 & 11,18 & 0 & 1,62 & 6,18 \\
& & & & & & & & \\
P4 & MMG & 9,95 & 72,54 & 13,47 & 3,56 & 58,92 & 4,04 & 1,79 \\
& MF & 9,16 & 75,87 & 10,27 & 3,27 & 62,50 & 4,70 & 1,37 \\
& FS & 54,66 & 27,56 & 15,45 & 10,25 & 0 & 2,33 & 5,91
\end{tabular}

${ }^{\mathrm{a} C N F}=$ carboidratos não fibrosos. 
3.2.7 Determinação da digestibilidade verdadeira da matéria orgânica e da digestibilidade aparente dos nutrientes

Deve ressaltar-se, que as alterações de composição bromatológica, notadamente, menor fração amido, e consequentemente elevação nos componentes FDN, FDA e MM, observadas para as fontes de concentrados energéticos, milho moído grosso e milho floculado, se deveram provavelmente à origem da partida e ataque por insetos respectivamente.

A determinação da digestibilidade da matéria orgânica inicialmente foi conduzida com a utilização da fibra em detergente neutro indigestivel (FDNindig), como marcador interno. Entretanto os valores obtidos, não se aproximaram dos observados na literatura. Dessa forma, optou-se pela estimativa da digestibilidade da matéria orgânica como sendo igual ao valor de NDT (nutrientes digestiveis totais) calculados pelo modelo multivariado proposto por Weiss et al. (1992), citado no NRC Dairy Catlle (2001):

NDT $(\%)=$ CNFdig. + Pbdig. + (Agdig. X2,25) + FDNdigest. -7

Onde:

NDT = nutrientes digestiveis totais, $\%$

CNFdig. = carboidratos não fibrosos digestíveis, $\%$

Pbdig. = proteína bruta digestivel, $\%$

Agdig. = ácidos graxos digestivel, \%

FDNdig = fibra detergente neutro digestível, \%

A utilização dessa equação equação permitiu a estimativa da digestibilidade verdadeira da matéria orgânica, uma vez que Weiss et al. (1992) determinou que em média o NDT metabólico fecal é seria de 7 pontos percentuais, como considerado no modelo proposto. 
Com os valores de digestibilidade verdadeira estimados, associados às estimativas de consumo de matéria seca, foi possível determinar a produção de MS fecal ( $\left.\mathrm{kg} \mathrm{dia}^{-1}\right)$ pela seguinte equação:

Produção de MS fecal $\left(\mathrm{kg} \mathrm{dia}^{-1}\right)=$ IMS - [IMS x (NDT/100)]

Onde:

IMS = ingestão de matéria seca, $\mathrm{kg} \mathrm{dia}^{-1}$

NDT = nutrientes digestíveis totais conforme Weiss et al. (1992) citado no NRC Dairy Cattle (2001)

A digestibilidade dos nutrientes foi calculada utilzando a seguinte fórmula:

Digestibilidade do Nutriente $=[($ Ing.Nut. - Excre. Nut. $) /$ Ing. Nut. $] \times 100$

Onde:

Ingestão do Nutriente $\left(\mathrm{kg} \mathrm{dia}^{-1}\right)=\%$ do nutriente na MS da dieta $x$ Ingestão de MS (kg dia $\left.{ }^{-1}\right)$

Excreção do Nutriente $\left(\mathrm{kg} \mathrm{dia}^{-1}\right)=\%$ do nutriente na MS das fezes $x$ Produção de MS fecal $\left(\mathrm{kg} \mathrm{dia}^{-1}\right)$

3.2.8 Ensaio de degradabilidade "in situ" da matéria seca para determinação do consumo de matéria seca da pastagem

O ensaio de degradabilidade "in situ" da MS foi realizado com a forragem colhida do estrato acima de $7 \mathrm{~cm}$ do solo, para o R1, e $37 \mathrm{~cm}$ do solo para R2, objetivando simular a forragem disponivel para pastejo pelos animais, submetidos a cada um dos residuos avaliados. 
As amostras foram secas em estufa com circulação de ar a $60^{\circ} \mathrm{C}$ por 72 horas, e moídas em moinhos tipo Willey com peneira de $5 \mathrm{~mm}$. Sub-amostras desse material, pesando aproximadamente 6 gramas, foram colocadas em sacos de nailon $10 \times 20 \mathrm{~cm}$, com porosidade de $45 \mu \mathrm{m}$, previamente pesados. Os sacos foram agrupados em uma argola com ganchos de metal, e esta argola foi presa a uma corda de nailon de $50 \mathrm{~cm}$, de modo a evitar que os saquinhos ultrapassassem o limite do compartimento ruminal. Os sacos foram posicionados submersos no rúmen de todos os garrotes de cada resíduo. Os horários utilizados para avaliar a degradabilidade foram: 0, 24, 48, 72 e 96 horas. Para cada horário haviam dois sacos de nailon. Os saquinhos foram incubados em ordem reversa, sempre iniciada às 7:30 horas, e retirados simultaneamente, visando reduzir os possiveis erros no momento da lavagem.

Retirados do rúmen, os saquinhos foram lavados imediatamente em água corrente até que essa se apresentasse limpa. Os sacos referentes ao tempo 0 foram lavados juntamente com os demais. Os saquinhos foram levados para secagem em estufa de ventilação forçada a $60{ }^{\circ} \mathrm{C}$ por 72 horas, e o peso foi registrado para determinação da MS do resíduo.

Os dados das amostras incubadas foram processados utilizando o programa "fit curve" desenvolvido pela Rowett Research Institute, Aberdeen, Escócia. O programa oferece os parâmetros do modelo de degradabilidade ruminal segundo Orskov \& McDonald (1979), entre outras informações. As degradabilidades potenciais "in situ" da matéria seca foram calculadas de acordo com a equação:

$D g=a+b\left(1-e^{-c t}\right)$

Sendo:

$\mathrm{Dg}=$ degradabilidade estimada, \%;

$a=$ interseção da curva no tempo 0 , podendo ser interpretada como fração 
rapidamente solúvel, \%;

$\mathrm{b}=$ fração insolúvel em água, mas potencialmente degradável, \%;

$c=$ taxa de degradação da fração $b$ por hora, $\% h^{-1}$;

e = logaritimo natural;

$\mathrm{t}=$ tempo de incubação, $\mathrm{h}$;

$a+b=$ potencial de degradabilidade, $\%$;

\subsubsection{Análise estatística}

O experimento foi conduzido sob um delineamento tipo quadrado latino 4 $x 4$, contendo um quadrado para cada resíduo pós pastejo. Em cada quadrado latino (resíduo pós pastejo) foram estudados quatro suplementos (S0, S1, S2 e S3). Foi adotado o nível de significância de $5 \%$ para o teste $\mathrm{F}$. Utilizou-se contrastes não ortogonais para comparação entre as médias dos suplementos utilizados, com nivel de significância de $5 \%$. Os contrastes utilizados foram:
a)S0 vs S1+S2+S3
b)S3 vs $S 1+S 2$
c)S1 vs S2
d)SO vs S1+S2
e)SO vs S3

Para análise da variância e comparação das médias de consumo e digestibilidade aparente foi utilizado o procedimento GLM do programa SAS (1991). As médias foram obtidas através dos quadrados mínimos, utilizando o comando LSMEANS do programa SAS (1991). O quadro da análise de variância proposto para os dados de consumo, e digestibilidade aparente é apresentado na tabela 3. Como não houve interação entre resíduo pós pastejo e a suplementação sobre os parâmetros avaliados, a interação foi retirada do modelo.

As variáveis $\mathrm{pH}, \mathrm{AGV}$ 's e $\mathrm{N}-\mathrm{NH}_{3}$ foram analisadas estatisticamente como 
parcelas subdivididas, repetidas no tempo. Os efeitos de resíduo pós pastejo (RPP), suplemento, interação RPP $\times$ suplemento, animal e período foram testados com relação às parcelas. A interação horário de coleta $x$ tratamentos, foi testada com relação às subparcelas, através do procedimento MIXED do GLM do programa estatísitico SAS (SAS 1991). O quadro de análise de variância é apresentado na tabela 4.

Tabela 3. Esquema de análise da variância para o ensaio de consumo e digestibilidade aparente.

\begin{tabular}{lc}
\hline Causas de variação & Graus de liberdade \\
\hline Quadrado Latino & 1 \\
Animais (QL) & 6 \\
Suplementos & 3 \\
Período & 3 \\
Resíduo & 18 \\
Total & 31 \\
\hline
\end{tabular}

As diferenças entre os suplementos, para as variáveis avaliadas, foram verificadas através de contrastes não ortogonais como nível de significância de $5 \%$ :
a) $\mathrm{S} 0$ vs $\mathrm{S} 1+\mathrm{S} 2+\mathrm{S} 3$
b) $\mathrm{S} 3$ vs $\mathrm{S} 1+\mathrm{S} 2$
c) $S 1$ vs $S 2$
d) $\mathrm{SO}$ vs $\mathrm{S} 1+\mathrm{S} 2$
e) SO vs S3 
Tabela 4. Esquema de análise da variância para os dados pH, AGV's e N-NH analisados estatisticamente como parcelas subdivididas repetidas no tempo.

\begin{tabular}{lc}
\hline Causas de variação & Graus de liberdade \\
\hline Quadrado Latino & 1 \\
Suplementos & 3 \\
QL x Suplementos & 3 \\
Período & 3 \\
Animais (QL) & 6 \\
Horário & 11 \\
Horário x Quadrado Latino & 11 \\
Horário x Suplemento & 33 \\
Horário x Suplemento x Q. Latino & 33 \\
Resíduo & 279 \\
Total & 383 \\
\hline
\end{tabular}

\subsection{Resultados e discussão}

\subsubsection{Consumo de matéria seca, matéria orgânica e fibra detergente neutro}

O consumo de matéria seca da forragem expresso em porcentagem do peso vivo e $\mathrm{g} \mathrm{kg}$ de peso metabólico ${ }^{-1}$ sofreu efeito do resíduo pós pastejo, sem efeito da suplementação (Tabela 5). Este fato é explicado pela quantidade de matéria seca verde presente na pastagem no $\mathrm{R} 1$, na saída dos animais dos piquetes (Tabela 3 capítulo 4). Este valor esteve abaixo do limite de $2000 \mathrm{~kg}$ MS ha-1, estabelecido por Minson (1990), como mínimo para não restringir o consumo de pastagem.

Os valores observados para o consumo de forragem em porcentagem do peso vivo encontram-se dentro da amplitude observada para forragens tropicais por Thiago et al. (1991), Euclides et al. (1999) e Detmann et al. (2001) e abaixo daqueles obtidos por Ribeiro et al. (1997).

O consumo de matéria seca da forragem em relação ao peso metabólico (g.kg PM-1) apresentou diferença significativa entre os resíduos de matéria seca 
verde estudados (Tabela 5). Os valores encontrados no presente experimento encontram-se acima da média obtida por Detmann et al. (2001), que foi de 64,6 g.kg $\mathrm{PM}^{-1}$, para bovinos pastejando $B$. decumbens, no verão, recebendo suplementação protéico/energética.

A redução do consumo, quando se comparou os dois resíduos pós pastejo, explica-se pela menor disponibilidade de matéria seca de folhas observada no R1, comprometendo a capacidade de apreensão da forragem pelos animais, levando a uma redução no tempo de pastejo (Tabela 3 capítulo 4).

A suplementação não afetou o consumo de matéria seca da forragem, fato também observado por Detmann et al. (2001) que utilizou suplementos à base de milho ou farelo de trigo adicionados de farelo de soja. Vanzant et al. (1990) obteve resultados semelhantes ao obtidos nesse experirmento, não obtendo redução no consumo de matéria seca da forragem, em porcentagem do peso vivo, quando estudou a inclusão de níveis crescentes de sorgo na dieta de animais estabulados. 
Tabela 5. Médias dos quadrados mínimos do consumo de matéria seca da forragem (CMSF) e consumo de matéria seca total (CMST), forragem mais suplemento, em kg.dia ${ }^{-1}$, porcentagem do peso vivo (\% PV) e gramas.kg de peso metabólico ${ }^{-1}\left(\mathrm{~g} \mathrm{~kg} \mathrm{PM}^{-1}\right)$ de garrotes Nelore manejados em pastejo rotacionado sobre capim Tanzânia (Panicum maximum Jacq.) em dois resíduos pós pastejo (RPP) R1 e R2.

\begin{tabular}{|c|c|c|c|c|c|}
\hline & \multirow[t]{2}{*}{$\mathrm{R} 1^{\mathrm{c}}$} & \multirow[t]{2}{*}{$\mathrm{R} 2$} & \multirow[t]{2}{*}{$\mathrm{EPM}^{\mathrm{a}}$} & \multicolumn{2}{|c|}{ Efeitos Principais } \\
\hline & & & & RPP & SUP $^{6^{-}}$ \\
\hline \multicolumn{6}{|l|}{ CMSF } \\
\hline Kg MS dia ${ }^{-1}$ & 6,37 & 6,54 & 0,085 & 0,1742 & 0,3820 \\
\hline$\% \mathrm{PV}$ & 2,08 & 2,19 & 0,071 & 0,0120 & 0,4265 \\
\hline $\mathrm{g} \mathrm{kg} \mathrm{PM}^{-1}$ & 86,96 & 91,16 & 2,425 & 0,0258 & 0,4341 \\
\hline \multicolumn{6}{|l|}{ CMST } \\
\hline $\mathrm{Kg} \mathrm{MS} \mathrm{dia}{ }^{-1}$ & 7,55 & 7,72 & 0,082 & 0,1742 & 0,0001 \\
\hline$\% \mathrm{PV}$ & 2,46 & 2,59 & 0,0032 & 0,0139 & 0,0001 \\
\hline $\mathrm{g} \mathrm{kg} \mathrm{PM}^{-1}$ & 102,95 & 107,51 & 1,242 & 0,0233 & 0,0001 \\
\hline
\end{tabular}

${ }^{\mathrm{a} E P M}=$ erro padrão da média,

${ }^{b}$ SUP = efeito da suplementação com fonte de energia ou proteína.

${ }^{\mathrm{C}} \mathrm{R} 1=1000 \mathrm{~kg} \mathrm{~h}^{-1}$ de matéria seca verde, $\mathrm{R} 2=4000 \mathrm{~kg} \mathrm{~h}^{-1}$ de matéria seca verde.

Hess et al. (1996) observou efeito contrário ao detectado no presente experimento. Esses autores observaram redução no consumo de matéria orgânica da forragem quando se utilizaram de suplementos energéticos à base de milho ou farelo de trigo. Ressalta-se que nos dados apresentados por Hess et al. (1996) o efeito de substituição apresentou-se demasiadamente elvado elevado, atingindo valores superiores a 1.

A redução na ingestão de matéria seca da forragem na presença de 
suplemento, foi também observada por Jones et al. (1988) que utilizaram dose de $0,3 \%$ do PV de milho moído e por Pordomingo et al. (1991) que utizaram milho laminado, em níveis crescentes como suplementos.

O consumo de matéria seca total, sofreu elevação não somente pela maior disponibilidade de forragem presente no R2, em relação ao R1 (Tabela 3 capítulo 4), mas também em decorrência do uso da suplementação (Tabela 5). Detmann et al. (2001), registou consumo médio de matéria seca total, igual a $1,93 \%$ do peso vivo para animais em pastejo, e não observou efeito da suplementação sobre este parâmetro. Entretanto valores de consumo de matéria seca total, em relação ao peso vivo, superiores aos observados no presente experimento, foram registrados por Galloway et al. (1993), utilizando feno de gramínea tropical fornecido para bovinos estabulados, recebendo como suplemento diferentes tipos de grãos. Esses autores registraram consumo de matéria seca total acima de $3 \%$ do peso vivo.

O consumo de matéria seca, observado em relação ao peso metabólico, foi superior ao registrado por Detmann et al. (2001) que obtiveram média de $88,1 \mathrm{~g} \mathrm{~kg} \mathrm{PM}^{-1}$, e não encontraram efeito da suplementação. Mathis et al. (2000), registraram um consumo de matéria orgânica variando entre 87,5 a 94,4 $\mathrm{g} \mathrm{kg} \mathrm{PM}^{-1}$, para novilhos recebendo feno de capim bermuda (Cynodon dactylon) de valor nutritivo intermediário $(8,2 \%$ de $\mathrm{PB})$, suplementados com niveis crescentes de proteína degradável no rúmen, e não encontraram efeito da suplementação sobre o consumo de matéria orgânica total. Elizalde et al. (1998) também não encontraram efeito do uso de suplementos protéicos ou energéticos sobre o consumo de matéria seca total.

No presente experimento, a suplementação exerceu efeito positivo sobre o consumo de matéria seca total provavelmente em função dos coeficientes de substituição aferidos no experimento terem sido inferiores a 1 (Tabela 6). Minson (1990) e Paterson et al. (1994) encontraram coeficiente de substituição médio de 0,69 . Coeficientes de substiruição maiores são registrados quando a 
disponibilidade e o valor nutritivo da forragem são maiores. Entretanto outros fatores que apresentaram efeitos marcantes sobre o coeficiente de substituição foram, a origem e a quantidade do concentrado oferecido aos animais (Minson, 1990; Paterson et al. 1994). Os coeficientes de substituição para fontes de amido como o milho moído grosso e milho floculado foram mais próximos de 1 (Tabela 6).

Hess et al. (1996) encontraram efeito de substituição variando entre 1,97 a 2,38, com redução na ingestão de matéria seca da forragem $(P<0,01)$ e redução na ingestão de matéria seca total $(P<0,05)$, ao compararem a suplementação de fontes de fibra de alta digestibilidade com amido. Coeficientes de substituição elevados, superiores a 1, também foram observados por Pordomingo et al. (1991) que registraram redução no consumo de forragem quando o consumo de milho laminado esteve entre 0,4 e $0,6 \%$ do PV. Entretanto, níveis inferiores de suplementação $0,2 \%$ do peso vivo, provocaram coeficiente de substuição negativo, determinando aumento no consumo de matéria seca da forragem.

Os valores para coeficiente de substituição para os tratamentos contendo farelo de soja, nos resíduos R1 e R2, obtidos no presente experimento foram numericamente menores e mais próximos a zero (Tabela 6). Em geral, o uso de suplementos protéicos promove aumento de consumo de forragem quando essa é de baixo valor nutritivo, caracterizando o coeficiente de substituição negativo. Entretanto, à medida que o valor nutritivo da forragem é elevado, o consumo de forragem sofre pequenas alterações ou nenhuma, demonstrando deslocamento do coeficiente de substituição para próximo de zero (Paterson et al. 1994).

Houve efeito da origem do suplemento sobre o consumo de matéria seca total (Tabela 7). De forma geral, a suplementação incrementou o consumo de matéria seca total, e o uso de suplementos energéticos elevou o consumo de matéria seca total quando comparado à suplementação com farelo de soja $(p=$ 
0,0001).

Tabela 6. Coeficiente de substituição observado para o fornecimento de ingredientes concentrados sobre o consumo de matéria seca de forragem $\left(\mathrm{kg} \mathrm{dia}^{-1}\right)$, por garrotes Nelore manejados sob pastejo rotacionado em capim Tanzânia (Panicum maximum Jacq.) sobre dois resíduos pós pastejo (RPP) R1 e R2.

\begin{tabular}{lccc}
\hline & \multicolumn{3}{c}{ Suplementos $^{\mathrm{a}}$} \\
\cline { 2 - 4 } RPP & $\mathrm{S} 1$ & $\mathrm{~S} 2$ & $\mathrm{~S} 3$ \\
\hline R1 & $0,86(0,2$ a 1,51$)$ & $0,91(0,36$ a 1,72$)$ & $0,16(-1,08$ a 1,71$)$ \\
R2 & $0,95(0,31$ a 1,75$)$ & $0,75(0,82$ a 1,18$)$ & $0,31(-0,43$ a 1,98$)$
\end{tabular}

${ }^{\mathrm{a} S 1}=2 \mathrm{~kg} \mathrm{MS}$ de milho moído grosso; $\mathrm{S} 2$ = $2 \mathrm{~kg} \mathrm{MS}$ milho floculado; $\mathrm{S3}=0,7$ $\mathrm{kg}$ MS farelo de soja.

${ }^{\mathrm{b}} \mathrm{R} 1=1000 \mathrm{~kg} \mathrm{~h}^{-1}$ de matéria seca verde, $\mathrm{R} 2=4000 \mathrm{~kg} \mathrm{~h}^{-1}$ de matéria seca verde

Essa diferença ocorreu, provavelmente, em função da diferença entre as quantidades de suplemento energético e de suplemento protéico oferecidos aos animais. Krysl et al. (1989) não observaram efeitos significativos da inclusão de $0,5 \mathrm{~kg} \mathrm{dia}^{-1}$ de suplemento protéico (farelo de soja) ou energético (sorgo floculado) na dieta de animais sobre o consumo de forragem por animais em pastejo. Pequenas variações na quantidade de suplemento energético fornecido $(0,34 \%$ a $0,48 \%$ do PV) para animais em pastejo, também não promoveram incrementos significativos sobre o consumo de matéria orgânica total (Hess et al. 1996). Pordomingo et al. (1991) não observaram efeito de níveis crescentes de milho laminado sobre o consumo de matéria orgânica total, provavelmente, em função dos elevados coeficientes de substituição obtidos com o incremento nas quantidades de suplementos oferecidos. Entretanto, não houveram diferenças significativas quando foram comparadas as formas de processamento do milho $(\mathrm{P}>0,05)$. 


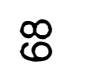

).

동

ब응

惫

E

包

$\overline{0}$

잉 응

年

을

\%

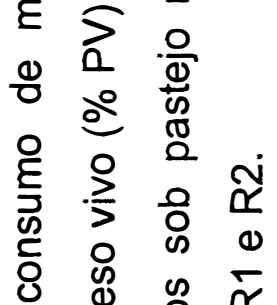

응 웅

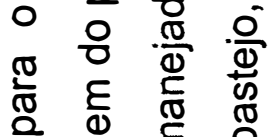

잉

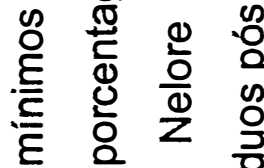

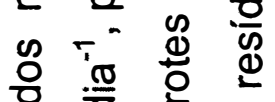

\%

몽

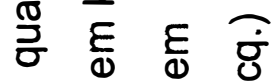

ช0

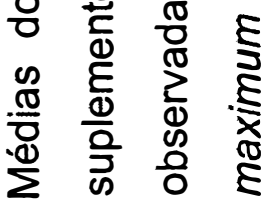

N

$\frac{\pi}{10} \frac{0}{\circ}$

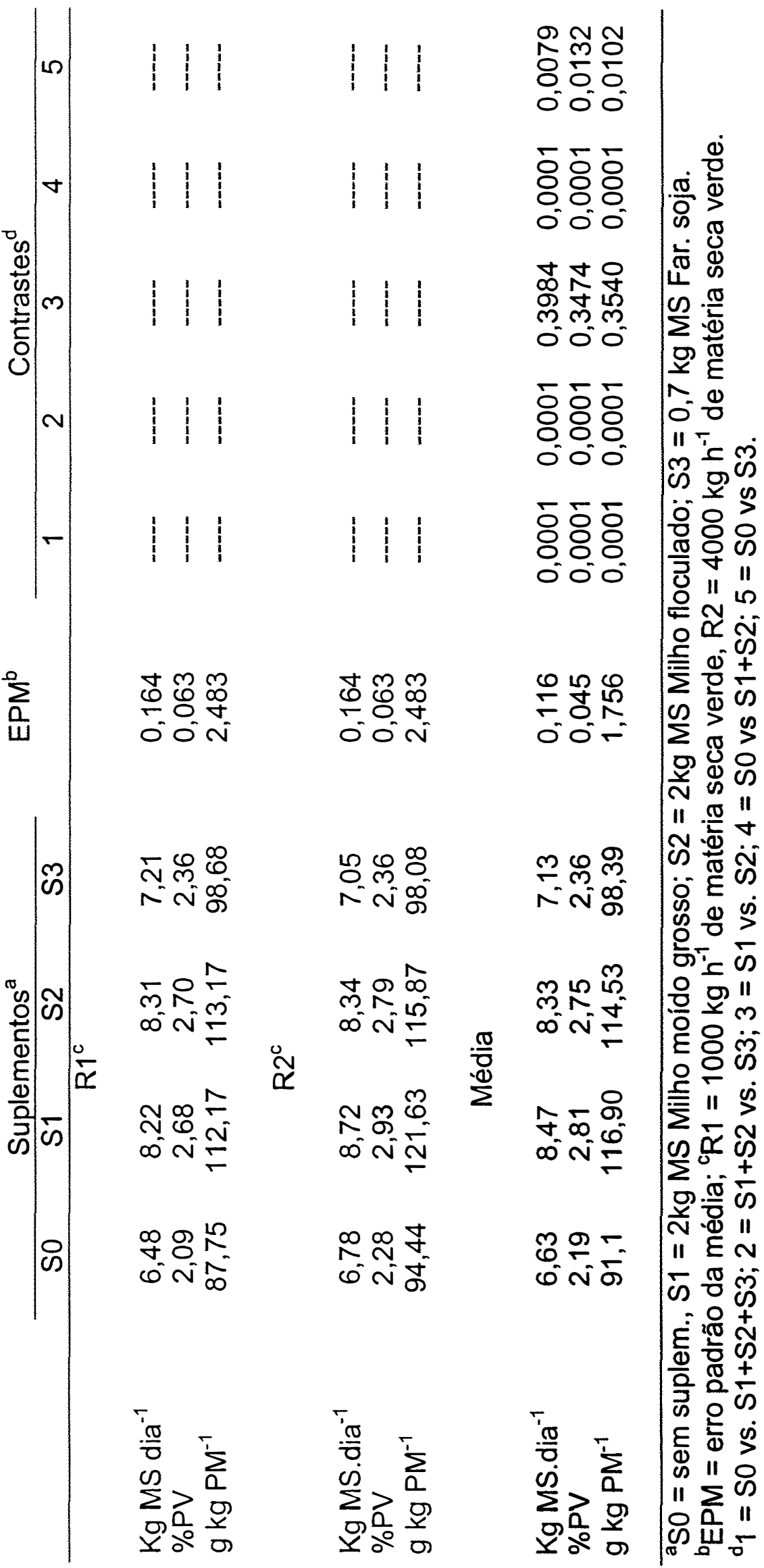


8

+

$\sum_{0}^{4} \sum_{0}^{\frac{\pi}{0}}$

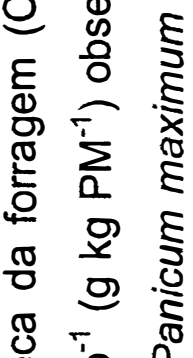

\&

它 它

ㅇํㅇ \&

을 잃

ग

ठ응으

- E ष্

지 बे 든

त 2 త্ర

ต 2 은

을 을

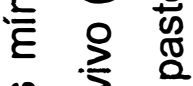

융 \& 응

ช্ㄴ \& \&

흄 음

क ह $\frac{\mathbb{N}}{\mathrm{D}}$

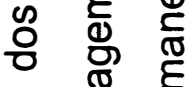

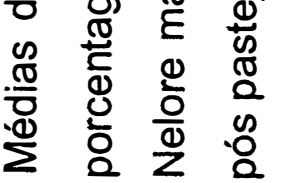

$\infty$

$\frac{\pi}{\frac{0}{10}}$

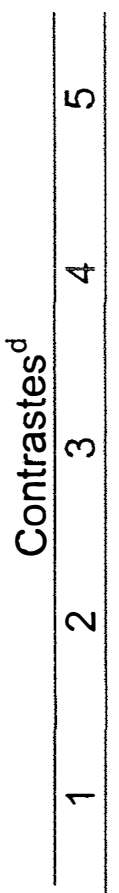

111
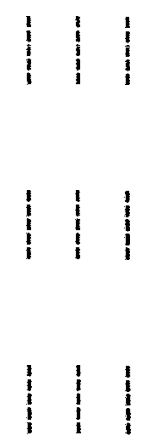

(111

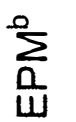

$\infty$

ถัก

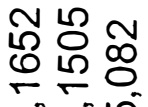

के

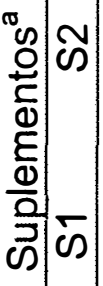

이

$\frac{0}{x}$

ำ ต

๑ก

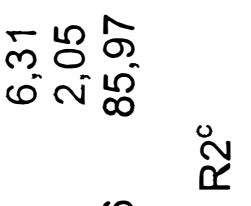

$\begin{array}{lll}\infty & R \\ + & 0 & N \\ 0 & N & N\end{array}$

m $\cong \stackrel{m}{\circ}$

बं

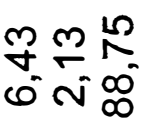

ก $\sim$ ๑ $\sim \infty$ $\stackrel{\sim}{\alpha}$ N@® ०त ต

बִ

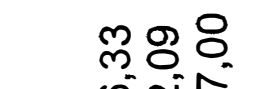
๑ก<smiles></smiles>

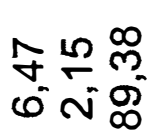

धु बून

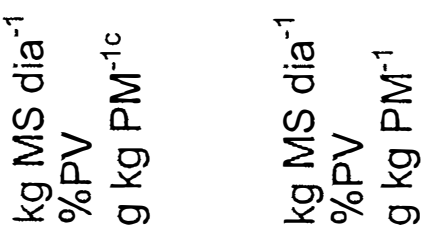

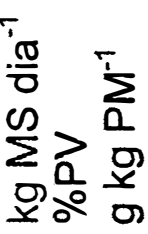

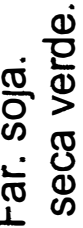

C)

$\sum \pm$

우 है

등 음

लि

후

을 용

을

ชั ชิ

ㅇ

$\sum_{0}^{0}$ 心

N

잉

N

II

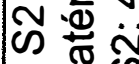

के है

भु

ธั.

음 에 1

응 수

틍 해

을 을

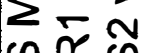

๘01

웅 잉

ก E I

ज ठ

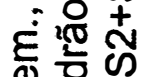

윽 뜽

ต 은

ह ํํํ ग

\& 110

II $\sum$ क

은

늠 


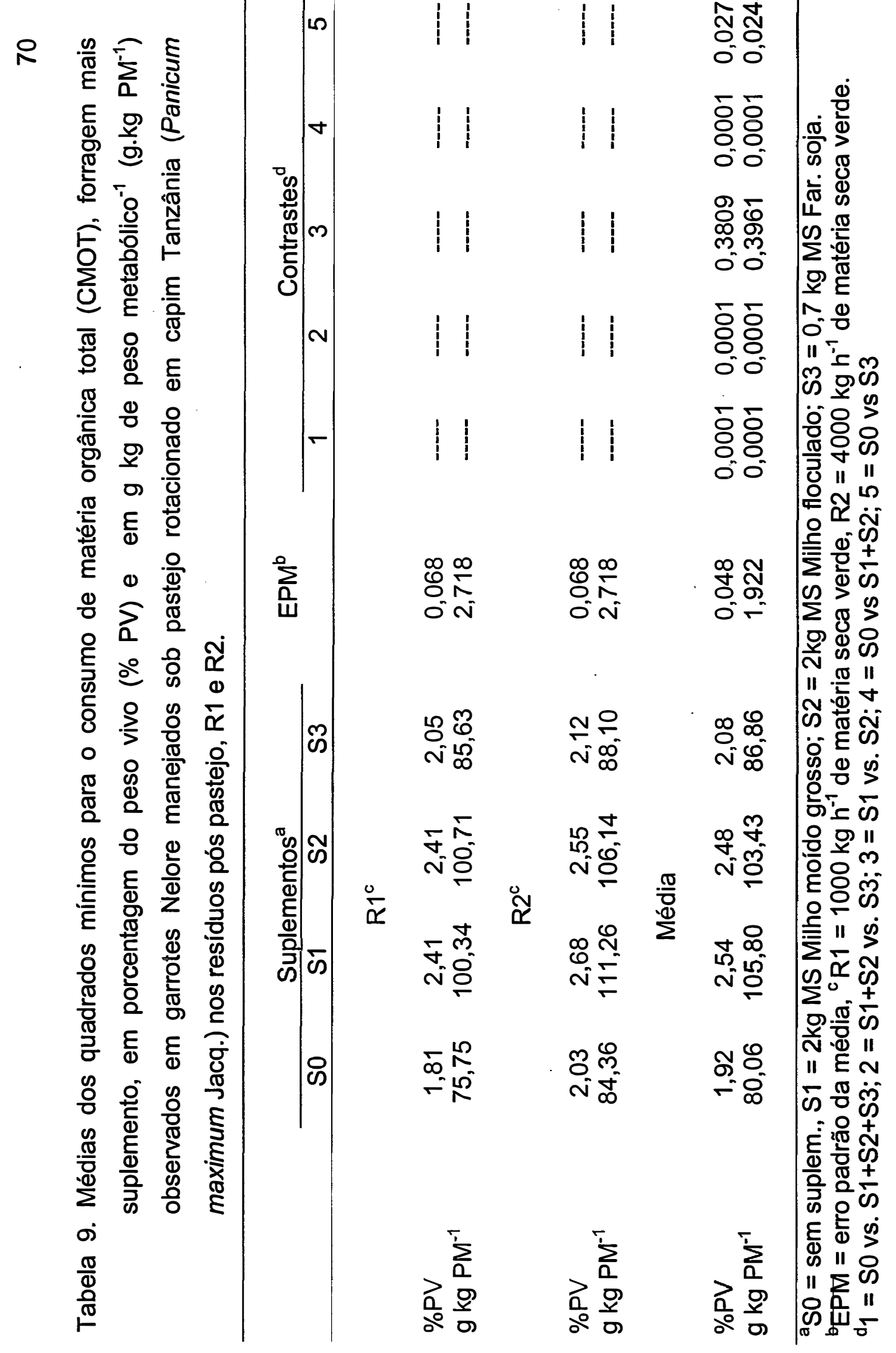


Na tabela 9 são apresentados os dados de consumo de matéria orgânica total em porcentagem do peso vivo e em $\mathrm{g} \mathrm{kg}$ de peso metabólico ${ }^{-1}$ e na tabela 9 os consumos de FDN total, expressos em porcentagem do peso vivo e em $\mathrm{g}$ $\mathrm{kg}$ de peso metabólico.

A análise do consumo de matéria orgânica foi reduzida devido a elevada quantidade de matéria mineral no menor resíduo (R1), originada pela contaminação por solo da forragem colhida, via pastejo simulado.

$\mathrm{O}$ consumo de matéria orgânica total sofreu efeito do resíduo pós pastejo ( $\mathrm{P}<$ 0,01 ) e da suplementação (Tabela 9 ), acompanhando a mesma tendência do consumo de matéria seca total, demonstrando que a maior disponibilidade de matéria seca e a suplementação elevaram o consumo de energia pelos animais. Não houve interação significativa entre resíduo pós pastejo e suplementação para o consumo de matéria orgânica $(P>0,05)$. Não houve diferença significativa entre a origem do suplemento energético, embora 0 consumo tenha sido elevado quando comparou-se a suplementação energética com a suplementação protéica (Tabela 9).

O uso de suplementos elevou o consumo de matéria orgânica (MO) em g $\mathrm{kg}$ peso metabólico ${ }^{-1}$ em dietas contendo forragem de baixo valor nutritivo (Heldt et al., 1999 e Olson, et al. 1999). Esse fato está de acordo com os dados demonstrados na tabela 9. Entretanto, o efeito mais acentuado nos experimentos conduzidos por Heldt et al. (1999) e Olson et al. (1999) se deveu a inclusão e aumento nos níveis de proteína degradável no rúmen, desconsiderando o efeito da inclusão de amido, em pequenas quantidades, pois o principal fator limitante à ingestão de matéria orgânica nestes casos, se constitui no baixo teor de proteína.

Quando se comparou o uso de suplementos protéico e energético em pequenas quantidades para suplementar forragens de bom valor nutritivo, não foram detectados efeitos da suplementação e nem da origem de suplemento, sobre o consumo de matéria orgânica em relação ao peso vivo dos animais (Krysl et al. 1989). 
A comparação entre duas fontes de energia não apresentou resultados significativos, embora o uso de suplementos energéticos tenha elevado o consumo de matéria orgânica em $\mathrm{g} \mathrm{kg}$ de $\mathrm{PM}^{-1}$ de animais consumindo forragem de boa qualidade (Hess et al. 1996).

$\mathrm{O}$ consumo de FDN em relação ao peso vivo e em g kg PM${ }^{-1}$ foi afetado apenas pelo resíduo pós pastejo (Tabela 10). Os animais manejados sobre o R2 apresentaram maior consumo de FDN devido ao maior consumo de matéria orgânica (Tabela 9) pelos animais submetidos a este tratamento, uma vez que a concentração de FDN na matéria orgânica da forragem coletada simulando o pastejo no R2 foi ligeiramente inferior ao mensurado no R1 em três dos quatro períodos de avaliação (Tabela 1).

Tabela 10. Médias dos quadrados mínimos para o consumo de FDN total, forragem mais suplemento, em porcentagem do peso vivo (\% PV) e em g.kg de peso metabólico-1 $\left(\mathrm{g} \mathrm{kg} \mathrm{PM}^{-1}\right)$ em garrotes Nelore manejados sob pastejo rotacionado em capim Tanzânia (Panicum maximum Jacq.) nos resíduos pós pastejo, R1 e R2.

\begin{tabular}{|c|c|c|c|c|c|}
\hline & \multirow[t]{2}{*}{$\mathrm{R} 1^{\mathrm{d}}$} & \multirow[t]{2}{*}{$\mathrm{R} 2$} & \multirow[t]{2}{*}{$\mathrm{EPM}^{\mathrm{a}}$} & \multicolumn{2}{|c|}{ Efeitos Principais } \\
\hline & & & & $\mathrm{RPP}^{\mathrm{E}}$ & SUP $^{\mathrm{b}}$ \\
\hline$\% P V$ & 1,41 & 1,52 & 0,027 & 0,0091 & 0,5527 \\
\hline$g \mathrm{~kg} \mathrm{PM}^{-1}$ & 58,88 & 63,18 & 1,113 & 0,0154 & 0,5780 \\
\hline
\end{tabular}

\footnotetext{
a'EPM = erro padrão da média.

${ }^{\mathrm{b}} \mathrm{RPP}=$ resíduo pós pastejo.

'SUP = efeito da suplementação com fonte de energia ou proteína.

${ }^{d} \mathrm{R} 1=1000 \mathrm{~kg} \mathrm{~h}^{-1}$ de matéria seca verde, $\mathrm{R} 2=4000 \mathrm{~kg} \mathrm{~h}^{-1}$ de matéria seca verde.
}

Os valores observados para consumo de FDN em relação ao peso vivo (Tabela 10) estão acima de $1,28 \%$ do peso vivo, valor médio obtido por Detmann et al. (2001), para bovinos manejados em pastagens de Brachiaria 
decumbens com alta disponibilidade de forragem, mantida acima de $4000 \mathrm{~kg}$ $\mathrm{ha}^{-1}$ de matéria seca verde; e também superior ao valor proposto por Mertens (1994) como adequado para atingir máximo consumo. Justificando os desempenhos mais elevados apresentados por bovinos manejados em pastagens tropicais. Mathis et al. (2000) observaram ingestão de 52,7 a $59,4 \mathrm{~g}$

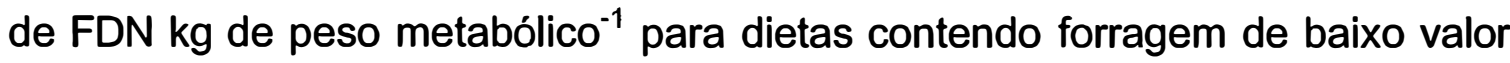
nutritivo suplementadas com proteina degradável no rúmen, próximos aos valores encontrados neste experimento (Tabela 10).

Não houve efeito da suplementação sobre o consumo de parede celular da dieta e nem interação resíduo pós pastejo $x$ suplemento $(P>0,05)$. Esses resultados estão de acordo com os observados por Elizalde et al. (1999a) e Detmann et al. (2001) que não observaram efeito da suplementação sobre o consumo de FDN da dieta total contendo forragens de elevado valor nutritivo.

A suplementação energética aumentou o consumo de FDN de gramíneas tropicais e temperadas de bom valor nutritivo (Jones et al. 1988) enquanto Bodine et al. (2001) observaram efeito positivo, tanto da suplementação protéica quanto da suplementação energética, sobre o consumo de FDN em relação ao peso vivo dos animais, para forragem de baixo valor nutritivo. Provavelmente, a proteína dos suplementos oferecidos tenham minizado o balanço protéico negativo da dieta. Bodine et al. (2001) observaram incrementos no consumo de FDN de 1,0 para $1,6 \%$ do peso vivo.

Mathis et al. (2000) não observaram efeito positivo da inclusão de níveis de crescentes de proteína degradável no rúmen sobre o consumo de FDN total (da dieta) contendo 8,2\% de PB na MS, tendo variado entre $67,0 \mathrm{~g} \mathrm{~kg} \mathrm{PM}^{-1}$ para os animais suplementados e $72,5 \mathrm{~g} \mathrm{~kg}$ de $\mathrm{PM}^{-1}$ para animais sem suplementação, valores esses, superiores aos obtidos nesse ensaio (Tabela 10).

Matejovsky \& Sanson (1995) avaliaram o efeito da suplementação protéica e/ou energética sobre o consumo de FDN, em \% do peso vivo da dieta total (forragem + suplementos), com o fornecimento de fenos de alto e baixo 
valor nutritivo. Não observaram efeito do suplemento protéico sobre o consumo de FDN de feno de alto valor nutritivo, entretanto a suplementação protéica elevou o consumo de FDN da dieta constituida por feno de baixo valor nutritivo. $\mathrm{O}$ aumento no consumo de FDN de dietas à base de forragens de reduzido valor nutricional foi observado por Olson et al. (1999) e Heldt et al. (1999). Entretanto, a utilização de grãos de cereais como suplementos reduziu o consumo de FDN, tanto para dietas contendo feno de alto como para dietas contendo feno de baixo valor nutritivo (Matejovsky \& Sanson, 1995).

\subsubsection{Parâmetros ruminais}

As médias dos valores de $\mathrm{pH}$, amônia e ácidos graxos voláteis (AGV's) entre os resíduos pós pastejo avaliados constam da tabela 11. Observa-se, nessa tabela, que houve efeito significativo do resíduo pós pastejo sobre o valor de $\mathrm{pH}$ ruminal $(P=0,0001)$. Os animais manejados no resíduo com menor disponibilidade de matéria seca verde (R1) apresentaram $\mathrm{pH}$ ruminal médio inferior aos animaïs manejados no R2. Esse fato poderia ser explicado pelas maiores concentrações de ácidos graxos voláteis totais, ácido acético e ácido propiônico $(P<0,05)$ apresentadas pelos animais provenientes do R1 (Tabela 11). Não houve efeito do resíduo de matéria seca verde pós pastejo, sobre a concentração ruminal de ácido butírico $(P>0,05)$ (Tabela 11). As causas da maior concentração de AGV's no líquido ruminal dos animais submetidos ao R1, não são aparentes, uma vez que estes animais consumiram menores quantidades de MS, MO e FDN, confirmado pelo menor tempo de ruminação apresentado pelos animais neste resíduo pós pastejo (Tabela 2 capítulo 4). Esta fenômeno contraria a expectativa, uma vez que a produção de AGV's totais sofre elevação à medida que o consumo dos animais é elevado (Church, 1993). Sob esta ótica, o menor consumo de MS e FDN poderia induzir a ocorrência de menor diluição do substrato fermentável na fase líquida do rúmen, especialmente para os animais recebendo suplementação, criando a 
oportunidade para elevação na concentração de AGV's.

Além disso a produção de saliva, que é um agente tamponante ruminal, depende da atividade de ruminação, que por sua vez pode ser elevada ou reduzida em função do conteúdo de fibra e da quantidade de matéria seca consumida (Church, 1993; Dixon \& Stockdale, 1999). Neste caso o menor consumo de FDN, deprimiu a atividade de ruminação, reduzindo a produção de saliva, o que provavelmente dificultou o tamponamento do $\mathrm{pH}$ ruminal.

Houve efeito do horário ao longo do dia $(P=0,0001)$ sobre os valores de $\mathrm{pH}$ com os menores valores observados às 12 e 20 horas, 4 a 5 horas após a suplementação ter ocorrido (Figura 1), demonstrando o efeito do horário de oferta dos concentrados, embora os tratamentos sem suplementação tenham apresentado perfil similar. Chase \& Hibberd (1987) e Detmann et al. (2001) observaram reduções no $\mathrm{pH}$ ruminal, 3 a 6 horas após o fornecimento de suplementos para bovinos consumindo feno de baixo e pastagem de alto valor nutritivo, respectivamente. Apenas os animais manejados sob R1, demonstraram valores de $\mathrm{pH}$ ruminal inferiores a 6,2, considerado como limite por Dixon \& Stockdale (1999) para evitar redução drástica na digestão da fibra (Figura 1). Entretanto, não houve efeito do resíduo de matéria seca verde pós pastejo sobre a digestibilidade da FDN (Tabela 13).

O uso de suplementos reduziu o valor de $\mathrm{pH}$ ruminal médio, embora não tenham sido detectadas diferenças significativas entre as origens de suplementos (Tabela 11), com valores médios sempre acima de 6,2.

A redução do $\mathrm{pH}$ ruminal médio, para animais suplementados, está de acordo com Bodine et al. (2001), Brake et al. (1989) e Vanzant et al. (1990). Entretanto, Bodine et al. (2001) observaram diferenças para os valores de $\mathrm{pH}$ ruminal de animais recebendo fontes de energia ou de proteína suplementar o que discorda dos dados apresentados na Tabela 11. 
Tabela 11. Médias dos quadrados mínimos para as características de fermentação ruminal observadas em garrotes Nelore manejados sob pastejo rotacionado em capim Tanzânia (Panicum maximum Jacq.) em dois resíduos pós pastejo (RPP), R1 e R2.

\begin{tabular}{lcccccc}
\hline & \multirow{2}{*}{$\mathrm{R}^{\mathrm{d}}$} & $\mathrm{R} 2$ & $\mathrm{EPM}^{\mathrm{a}}$ & \multicolumn{3}{c}{ Efeitos Principais } \\
\cline { 6 - 8 } & & & & $\mathrm{RPP}$ & $\mathrm{SUP}^{\mathrm{b}}$ & $\mathrm{RPP}$ X SUP \\
\hline $\mathrm{pH}^{\mathrm{e}}$ & 6,20 & 6,54 & 0,0300 & 0,0001 & 0,0043 & 0,4606 \\
Amônia, $\mathrm{mg} \mathrm{dL}^{-1}$ & 11,15 & 9,60 & 0,8673 & 0,2280 & 0,0001 & 0,8517 \\
$\mathrm{AGV}^{\mathrm{c}}$ totais, $\mathrm{mM}$ & 160,69 & 143,63 & 3,3650 & 0,0027 & 0,2512 & 0,9542 \\
& & & & & & \\
Acético, $\mathrm{mM}$ & 117,57 & 105,09 & 2,775 & 0,0063 & 0,2616 & 0,9769 \\
Propiônico, $\mathrm{mM}$ & 27,80 & 24,40 & 0,7500 & 0,0058 & 0,0178 & 0,7841 \\
Butírico, $\mathrm{mM}$ & 12,29 & 11,57 & 0,3780 & 0,1989 & 0,0462 & 0,1411 \\
Isobutírico, $\mathrm{mM}$ & 0,78 & 0,74 & 0,0458 & 0,5054 & 0,0061 & 0,9299 \\
Valérico, $\mathrm{mM}$ & 1,00 & 0,86 & 0,0425 & 0,0281 & 0,0022 & 0,5753 \\
Isovalérico, $\mathrm{mM}$ & 1,24 & 0,99 & 0,0727 & 0,0241 & 0,0084 & 0,5779 \\
Relação Ac:Prop & 4,51 & 4,53 & 0,0880 & 0,8730 & 0,0006 & 0,7444 \\
& & & & & & \\
\hline
\end{tabular}

aEPM = erro padrão da média.

${ }^{\text {bSUP }}$ = efeito da suplementação com fonte de energia ou proteína.

${ }^{\mathrm{c}} \mathrm{AGV}$ = ácidos graxos voláteis.

${ }^{d} \mathrm{R} 1=1000 \mathrm{~kg} \mathrm{~h}^{-1}$ de matéria seca verde, $\mathrm{R} 2=4000 \mathrm{~kg} \mathrm{~h}^{-1}$ de matéria seca verde.

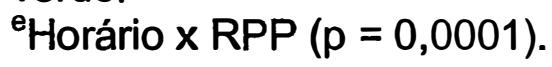

O uso de suplementos energéticos não provocou diferenças significativas quando comparado à utilização do farelo de soja como suplemento. Fato também observado por Krysl et al. (1989) que não registrou diferença significativa quando comparou a oferta de grãos de sorgo floculado contra a oferta de farelo de soja como suplementos. No entanto, esses autores também não registraram efeito da suplementação sobre o $\mathrm{pH}$ ruminal médio, quando compararam com o tratamento controle.

A redução do $\mathrm{pH}$ ruminal no tratamento contendo farelo de soja em relação ao controle apresentado nesse experimento, contraria as observações realizadas por McColum \& Galyean (1985). 


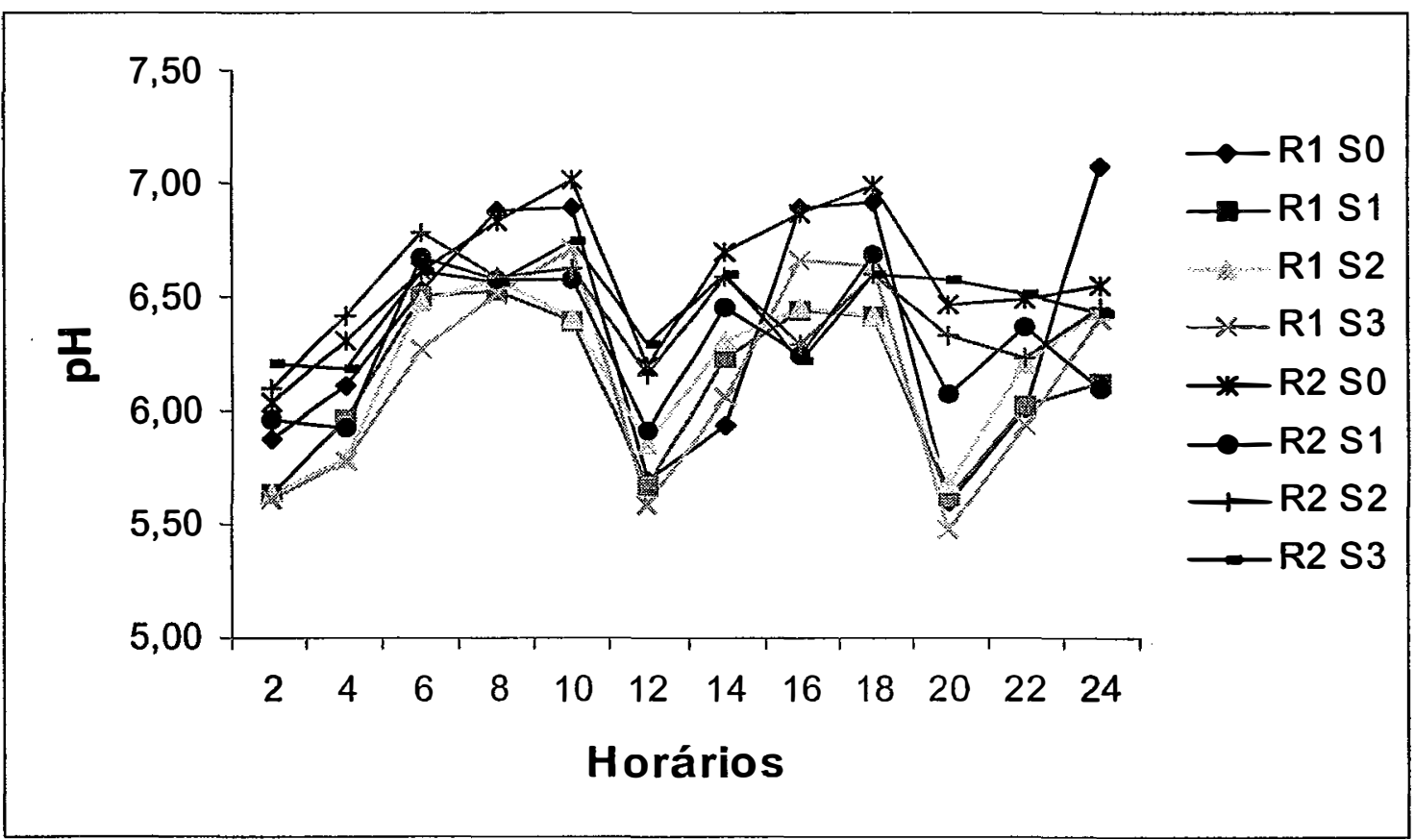

Figura 1 - Evolução temporal do pH ruminal em relação aos resíduos pós pastejo (R1 e R2) e a suplementação (S0, S1, S2 e S3).

A concentração de amônia no fluido ruminal não apresentou diferença significativa entre os resíduos pós pastejo avaliados, e nem interação resíduo pós pastejo x suplementação (Tabela 11), mas foi elevada pelo uso de farelo de soja como suplemento quando comparada aos demais suplementos (Tabela 12 e Figura 2).

O uso de suplementos protéicos é caracterizado pela elevação da concentração de amônia no fluido ruminal. Trabalhos realizados por Heldt et al. (1999), Olson et al. (1999) com forragens de baixo valor nutricional e Mathis et al. (2000) com forragem de valor nutritivo intermediário, observaram que níveis crescentes de suplementos protéicos exercem efeito linear, aumentando as concentrações de amônia no fluido ruminal. As concentrações médias de amônia no fluido ruminal registradas por Mathis et al. (2000), para bovinos recebendo feno de gramínea tropical com $8,2 \%$ de PB na MS, variaram entre 
5,88 a $16,9 \mathrm{mg} \mathrm{dL}^{-1}$, para novilhos sem suplementação e recebendo $0,124 \%$ do PV de proteína degradável no rúmen, respectivamente.

O valor mais elevado observado para a concentração de nitrogênio amoniacal no líquido rúminal por Mathis et al. (2000), encontra-se próximo do valor apresentado no presente experimento pelos animais suplementados com farelo de soja, que são superiores aos relatados por Bodine et al. (2000) que constataram uma concentração média de nitrogênio amoniacal no fluido ruminal de $9,0 \mathrm{mg} \cdot \mathrm{dL}^{-1}$.

Não houve efeito significativo do uso de energia sobre a concentração de amônia $(P=0,4678)$, contrariando as afirmações de Poppi \& McLenann (1995) e Rearte \& Pieroni (2001) de que a utilização de suplementos energéticos poderia reduzir as concentrações de nitrogênio amoniacal no rúmen pelo aumento na eficiência do uso do nitrogênio degradável presente na forragem. Provavelmente a proteina presente no concentrado energético, contribui para que não haja redução da concentração de nitrogênio amoniacal em relação ao controle (Obara et al. 1991), em decorrência da sincronização energia nitrogênio amoniacal.

Bodine et al. (2001) não observaram diferença na concentração média de amônia ruminal entre animais suplementados com fontes de proteína e de energia. Também não houve diferença entre a origem do suplemento energético, se assemelhando ao ocorrido no presente experimento. 


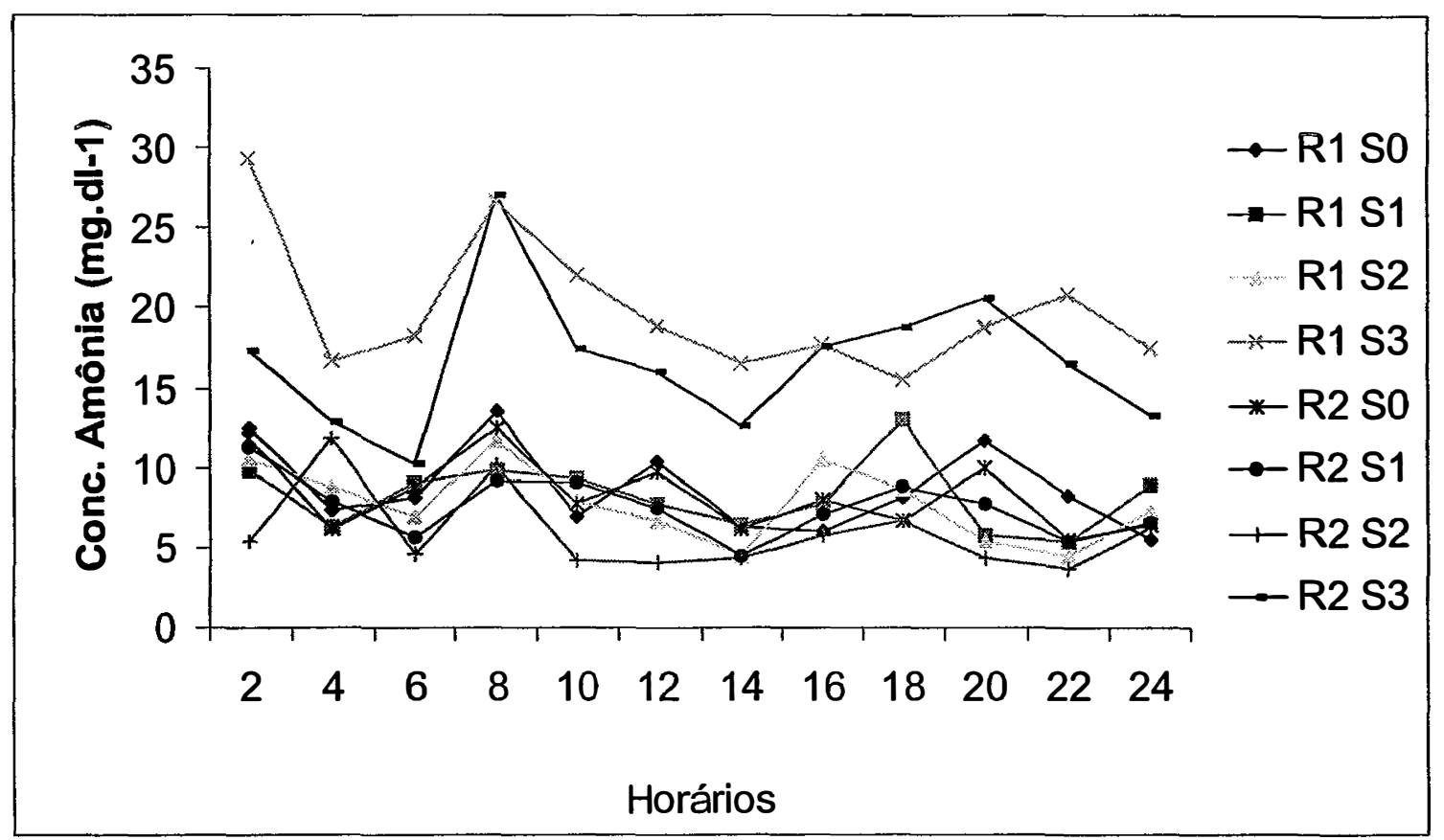

Figura 2 - Evolução temporal da concentração de nitrogênio amoniacal ruminal em relação aos resíduos pós pastejo (R1 e R2) e a suplementação (S0, S1, S2 e S3).

As concentrações de nitrogênio amoniacal no líquido ruminal sofreram maiores elevações no início da manhã e no final da tarde, após os horários de suplementação (Figura 2), mas estiveram sempre dentro ou acima da amplitude proposta por Satter \& Slyter (1974), como mínima para garantir a fermentação ruminal adequada. Entretanto, apenas os animais recebendo suplementação protéica, apresentaram concentração de nitrogênio amoniacal no líquido ruminal acima de $10 \mathrm{mg} \mathrm{dL}^{-1}$, considerada como limiar necessário por Leng et al. (1990), para animais alimentados com forragens tropicais. Aumentos nos níveis de nitrogênio amoniacal ruminal logo após a suplementação, foram registrados por McCollum \& Galyean (1985) usando farelo de algodão como suplemento, e por Detmann et al. (2001) utilizando concentrado protéico/energético.

Entretanto, no presente experimento a suplementação não alterou as concentrações molares de AGV's totais e de ácido acético. A ausência de efeito 
da inclusão de suplementos energéticos na dieta de animais em pastejo e recebendo feno, também foi observada por Chase \& Hibberd (1987) para forragens de baixo valor nutritivo, e por Pordomingo et al. (1991) para forragens de bom valor nutritivo. Entretanto, Galloway et al. (1993) observaram aumentos nas concentrações de AGV's totais quando forneceram grãos com maior taxa de degradação do amido, comparado ao controle e ao fornecimento de grãos de menor taxa de degradação do amido, que não diferiram entre si. Aumentos na concentração de AGV's totais foram observadas quando forragens de baixo valor nutritvo (<7\% de PB) foram suplementadas com fontes de proteína de alta degradabilidade ruminal (Heldt et al. 1999, Olson et al. 1999). Lippke et al. (2000) não encontraram efeito da disponibilidade de forragem e da suplementação sobre a concentração de ácidos graxos voláteis. 


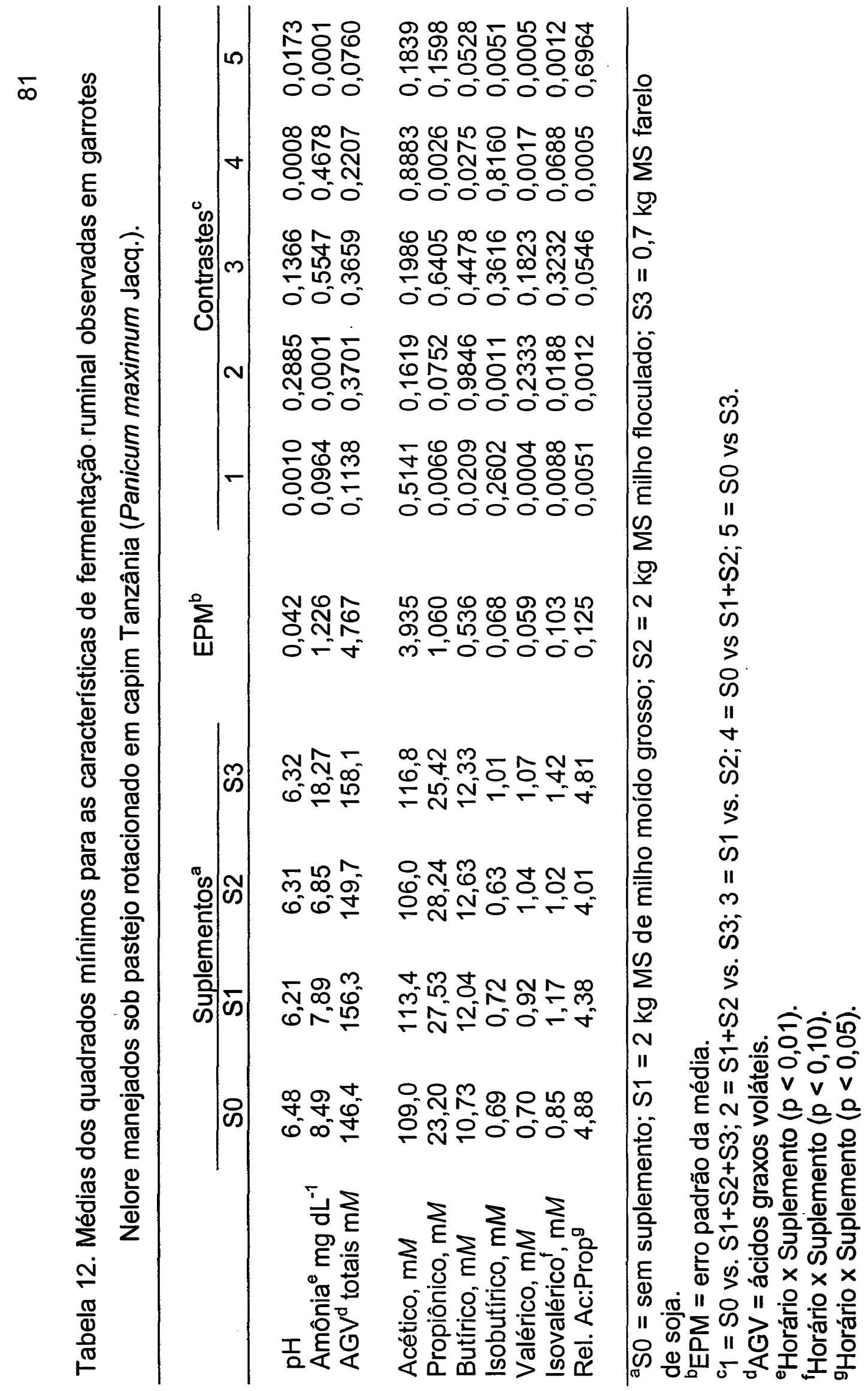


A suplementação energética reduz a proporção molar de ácido acético e aumenta a proporção molar de acido propiônico no fluido ruminal de animais, suplementados com concentrados, principalmente grãos (Church 1993, Van Soest, 1994), reduzindo a relação acetato:propionato (Church, 1993).

Entretanto, a utilização de suplementos no presente experimento não afetou a concentração de ácido acético, elevou apenas a concentração molar de ácido propiônico, causando redução na relação acético:propiônico (Tabela 12). Estes dados concordam com os apresentados por (Del Curto 1990) e são contrários às observações de Chase \& Hibberd (1987) e Kyrsl et al. (1989), que constataram redução na relação acético:propiônico, devido à menor concentração de ácido acético, sem alterações na concentração molar de ácido propiônico com o uso de suplementos. Hess et al. (1996) observaram redução na relação acético:propiônico pela redução na concentração de acetato e aumento na de ácido propiônico.

As concentrações molares de ácido propiônico foram elevadas com a utilização de suplementos energéticos, mas não sofreram alteração quando os animais receberam o farelo de soja como suplemento em relação ao controle (Tabela 12). Não houve diferença entre a forma de processamento do milho sobre a produção de ácido propiônico, fato também observado por Soriano et al. (2000) que suplementou vacas leiteiras em pastagens de alto valor nutritivo. Hess et al. (1996) não observaram efeito do tipo de suplemento (milho vs. farelo de trigo) sobre a produção de ácido propiônico. Entretanto, a floculação do grão de milho provoca aumentos na concentração de ácido propiônico no fluido ruminal (Joy et al. 1997; Lykos et al. 1997; Menezes Jr., 1999 e Lima 2000).

As concentrações de ácido butírico foram elevadas com a suplementação energética, entretanto o processamento do grão não afetou a concentração do ácido butírico no fluido ruminal (Tabela 12). Grigsby et al. (1997) observaram aumento nos níveis de ácido butírico, com o incremento da dose de amido em substituição à fibra da casca de soja, em suplementos fornecidos para bovinos alimentados com feno de baixo valor nutritivo. Elizalde 
et al. (1999) observou incrementos lineares nas concentrações de ácido butírico com aumento no fornecimento de milho moído para animais consumindo alfafa como volumoso.

Os ácidos graxos de cadeia ramificada sofreram acréscimo na cocnetração molar ruminal devido à suplementação protéica (Tabela 12). Esse fenômeno foi observado por Köster et al. (1996) e Heldt et al. (1999) que registraram níveis mais elevados de AGV's de cadeia ramificada no líquido ruminal de bovinos recebendo fonte de proteína degradável no rúmen e não observaram essa tendência para inclusão de carboidratos rapidamente fermentáveis no rúmen. Mathis et al. (2000) observaram efeito linear de niveis crescentes de proteína degradável no rúmen sobre a concentração molar de AGV's de cadeia ramificada. Os AGV's ramificados resultam da fermentação de alguns aminoácidos presentes na dieta e foram apontados como fatores de crescimento para bactérias fibrolíticas (Baldwin \& Allison, 1983).

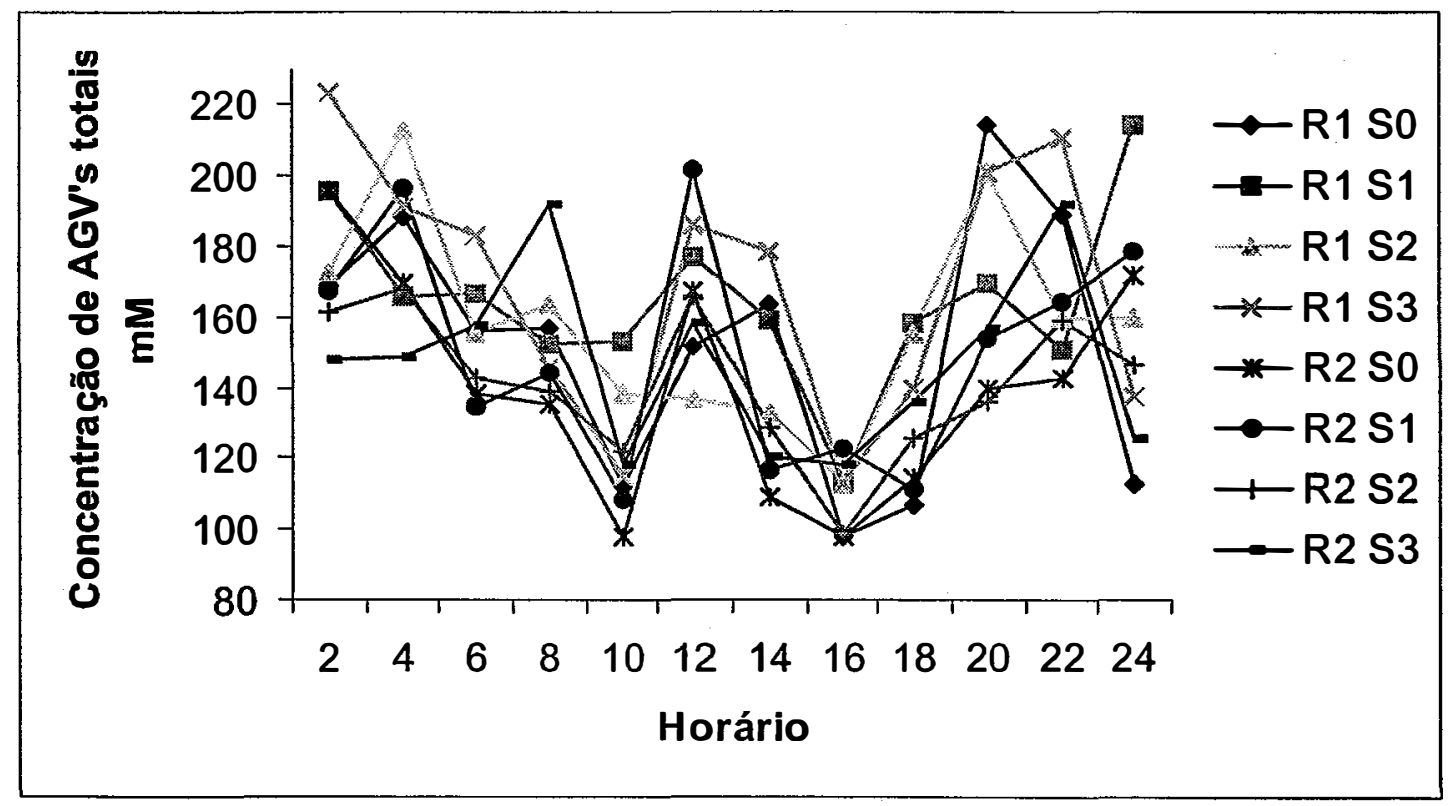

Figura 3 - Evolução temporal da concentração de ácidos graxos voláteis no líquido ruminal em relação aos resíduos pós pastejo (R1 e R2) e a suplementação (S0, S1, S2 e S3). 


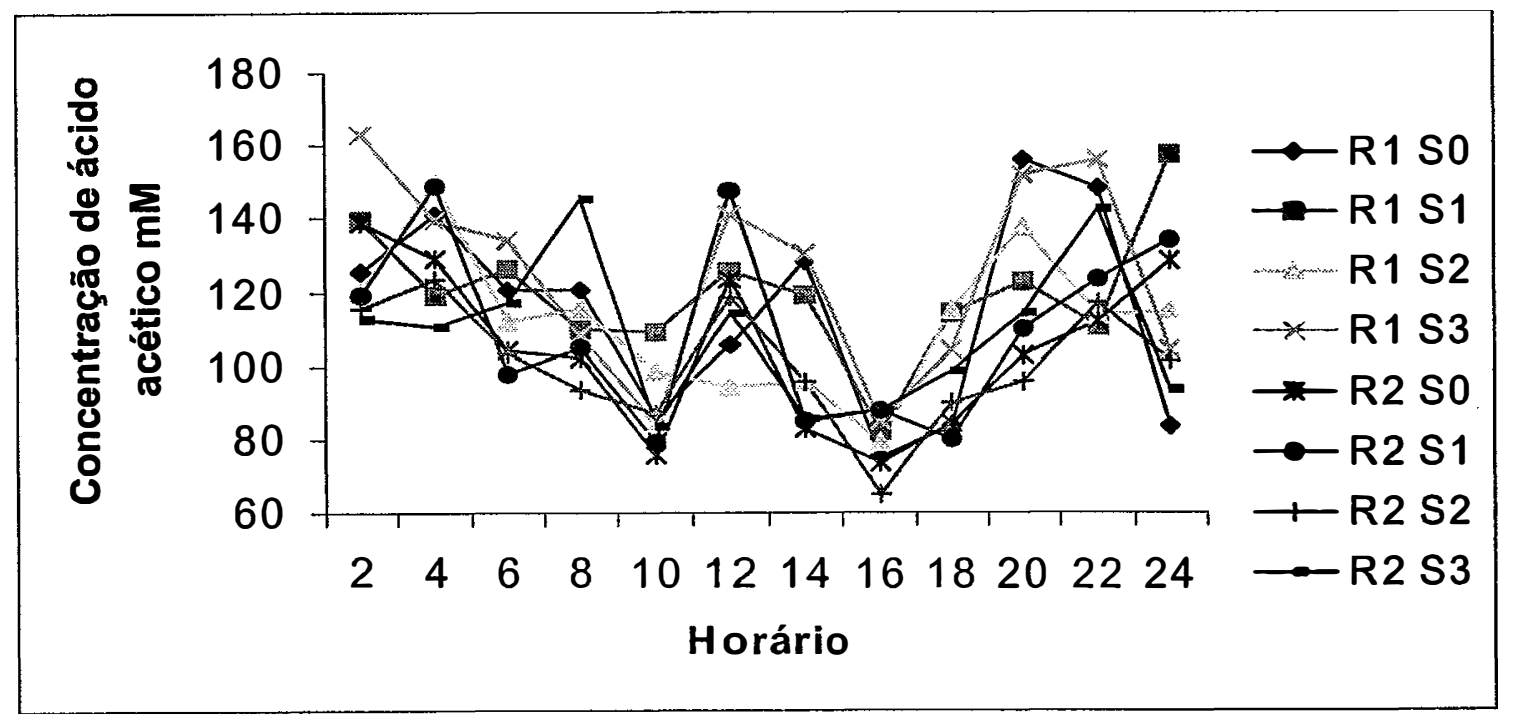

Figura 4 - Evolução temporal da concentração de ácido acético no líquido ruminal em relação aos resíduos pós pastejo (R1 e R2) e a suplementação (S0, S1, S2 e S3).

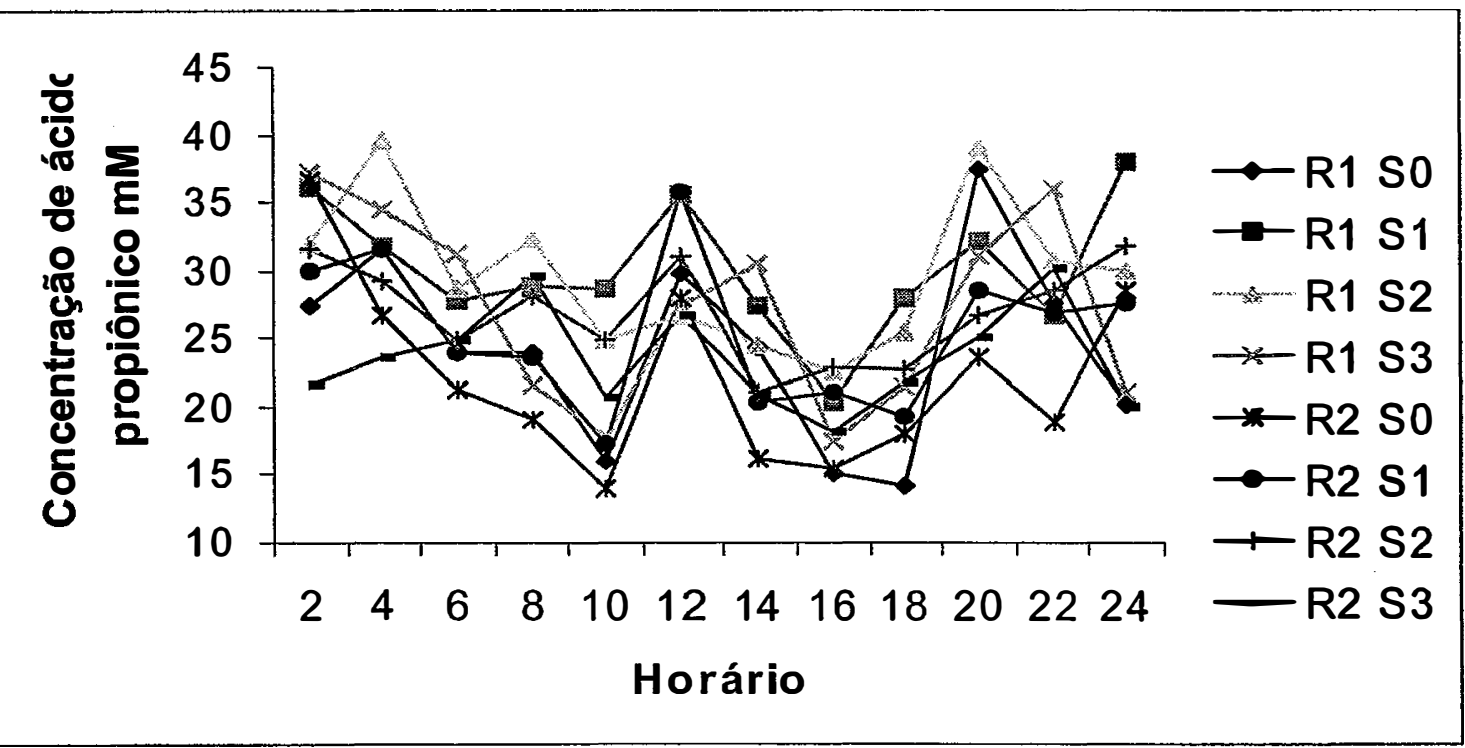

Figura 5 - Evolução temporal da concentração de ácido propiônico no líquido ruminal em relação aos resíduos pós pastejo (R1 e R2) e a suplementação (S0, S1, S2 e S3). 
Houve efeito do horário de amostragem $(P<0,001)$ sobre as concentrações de AGV's totais, ácido propiônico e ácido acético, no fluido ruminal. Elevações pronunciadas foram observadas duas horas após os horários de suplementação, tanto no periodo da manhã quanto no período da tarde (Figura 3, Figura 4 e Figura 5). Entretanto, não ocorrereram interações entre horário $x$ suplementação $(P>0,05)$, que podem ser explicadas pelo horário de pastejo dos animais que se concentrou sempre próximo aos horários de suplementação. Assim os picos de concentração molar dos AGV's ruminais também são explicados pelo hábito e horário de pastejo dos animais.

\subsubsection{Digestibilidade aparente}

Os dados de digestiblidade aparente dos nutrientes e da matéra orgânica, representado pelo NDT constam na tabela 13. Foram observados efeitos do resíduo pós pastejo e da suplementação $(P<0,05)$ sobre a digestiblidade de alguns nutrientes sem, no entanto, ocorrerem interações resíduo pós pastejo $x$ suplementação $(P>0,05)$. O NDT não sofreu alteração decorrente do resíduo pós pastejo, da suplementação e nem interação resíduo pós pastejo $x$ suplementação $(P>0,05)$.

Apenas as digestibilidades aparentes da PB e da FDA apresentaram efeito significativo $(P<0,05)$ do resíduo pós pastejo. $A$ digestibilidade aparente da $\mathrm{PB}$ foi superior para o R2 quando comparado à média observada para R1, fato que é explicado pelo maior conteúdo de PB da forragem produzida no R1 (Tabela 1) que exerceu um efeito de diluição sobre o nitrogênio metabólico fecal (Van Soest, 1994). 
Tabela 13. Médias dos quadrados mínimos da digestiblidade aparente da proteína bruta (PB), amido; fibra detergente neutro (FDN), fibra detergente ácido (FDA) e dos nutrientes digestíveis totais (NDT) observadas em garrotes Nelore manejados sob pastejo rotacionado em capim Tanzânia (Panicum maximum Jacq.) em dois resíduos pós pastejo (RPP), R1 e R2.

\begin{tabular}{llllll}
\hline \multicolumn{1}{r}{ Fração } & $\mathrm{R}^{\mathrm{c}}$ & $\mathrm{R} 2$ & $\mathrm{EPM}^{\mathrm{a}}$ & \multicolumn{2}{c}{ Efeitos Principais } \\
\cline { 5 - 6 } & & & & $\mathrm{RPP}$ & SUP $^{\mathrm{b}}$ \\
\hline PB (\%) & 52,69 & 63,41 & 0,9981 & 0,0001 & 0,0001 \\
Amido (\%) & 95,21 & 97,05 & 1,4255 & 0,3749 & 0,0001 \\
FDN (\%) & 66,28 & 65,98 & 0,5830 & 0,7222 & 0,0001 \\
FDA (\%) & 68,96 & 66,94 & 0,5457 & 0,0193 & 0,0001 \\
NDT (\%) & 59,28 & 59,80 & 0,9533 & 0,7089 & 0,5992 \\
\hline
\end{tabular}

${ }^{a}$ EPM = erro padrão da média,

bSUP = efeito da suplementação com fonte de energia ou proteína.

${ }^{c} \mathrm{R} 1=1000 \mathrm{~kg} \mathrm{~h}^{-1}$ de matéria seca verde, $\mathrm{R} 2=4000 \mathrm{~kg} \mathrm{~h}^{-1}$ de matéria seca verde.

A redução na digestibilidade aparente do FDA explica-se pelo menor consumo de matéria orgânica (Tabela 9). Segundo Merchen (1993) reduções no consumo de matéria seca estão associados a incrementos de digestibilidade da dieta, devido ao aumento no tempo de permanência da ingesta no trato gastrointestinal. $O$ tempo de permanência do alimento no sistema digestivo é um fator importante que determina a intensidade da digestão da fração fibrosa da forragem (Merchen 1993).

O NDT não sofreu efeito do resíduo pós pastejo e nem da suplementação (Tabela 13). Esse fato concorda com os dados observados por Detmann et al. (2001) que não observaram efeito significativo do uso de suplementos protéico e energéticos sobre a digestibilidade da matéria seca. 
Entretanto, a média obtida por Detmann et al. (2001) para o coeficiente de digestibilidade da MS foi de $65,4 \%$, acima dos valores médios observados para cada resíduo pós pastejo, no presente experimento. Vanzant et al. (1990) observaram redução linear na digestibiidade da MS da dieta, quando níveis crescentes de sorgo grão $\left(0 ; 0,45 ; 0,90\right.$ e $\left.1,80 \mathrm{~kg}^{-\mathrm{dia}^{-1}}\right)$ foram administrados para animais pastejando forragem com $11,9 \%$ de PB. Krysl et al. (1989) e Galloway et al. (1993) observaram incrementos na digestibilidade da matéria orgânica da dieta de animais suplementados com grãos.

Entretanto, ao integrar-se os dados de consumo médio de MS (kg cab ${ }^{-1}$ $\mathrm{dia}^{-1}$ ) com a respectiva concentração de NDT, obtida em cada tratamento, calculou-se os valores numéricos para a estimativa de ingestão de energia digestível diária. A ingestão média de NDT no R1 se apresentou cerca de 5,5\% inferior ao R2. Essa diferença numérica, foi ampliada para 9,3\% quando comparou-se os tratamentos contendo suplementação energética, nos dois resíduso pós pastejo. No menor resíduo pós pastejo (R1) a utilização de fontes energéticas aumentou o potencial de ingestão de NDT em $28 \%$, enquanto que no $\mathrm{R} 2$ esse aumento representou $20 \%$. Esses valores calculados indicam, como esperado, que a suplementação energética promoveu maior benefício relativo à condição de pastejo onde houve restrição de forragem para o animal. Entretanto, sugere também que, a adoção de suplementação energética em áreas de manejo de pastagens sob elevada oferta de forragem, poderia ampliar a ingestão de NDT, e provavelmente o desempenho dos animais.

$\mathrm{Na}$ tabela 14 observa-se o efeito do tipo da origem da fonte do suplemento sobre a digestibilidade aparente da PB, amido, FDN e FDA, e sobre o NDT.

A suplementação protéica elevou a digestiblidade aparente da PB pela diluição do nitrogênio metabólico fecal. Outros autores observaram efeito da inclusão de suplementos protéicos, para animais pastejando forragens de bom valor nutritivo, sobre a digestibilidade aparente da PB. Krysl et al. (1989) compararam o uso de farelo de soja ou sorgo floculado e obtiveram maior 
coeficiente de digestiblidade aparente da PB para os animais suplementados com farelo de soja em relação ao fornecimento de sorgo floculado e ao tratamento controle, que não diferiram entre si. Heldt et al. (1998) observaram o mesmo efeito que Krysl et al. (1989) ao compararem farelo de soja com farelo de trigo.

Elizalde et al. (1999b) observaram redução linear na digestibilidade do nitrogênio, na dieta à base de alfafa, para bovinos recebendo niveis crescentes de milho moído grosso na dieta, em função do maior teor de PB da alfafa em comparação ao milho. Detmann et al. (2001) não detectaram efeito significativo da suplementação com uma mistura protéico/energética, sobre a digestibilidade aparente da PB da dieta de animais pastejando $B$. decumbens. $O$ coeficiente médio de digestibilidade da PB registrado por Detmann et al. (2001) foi de 65,4 semelhante apenas ao apresentado pela dieta com farelo de soja (Tabela 14).

A digestibilidade do amido sofreu efeito acentuado do processamento do milho. Os animais suplementados com milho floculado apresentaram digestibilidade aparente do amido superior ao animais suplementados com milho moído grosso $(P=0,0001)$. Lima (2001) observou efeito da floculação do milho em comparação ao milho moído fino $(P=0,13)$ sobre a digestibilidade do amido fornecido para vacas leiteiras estabuladas, consumindo capim-elefante picado, colhido simulando o pastejo. A floculação aumenta a digestiblidade do amido do milho e do sorgo (Theurer et al. 1996; Nussio 1997; Theurer et al. 1999), pela quebra da matriz protéica, que envolve os grânulos de amido no endosperma do grão, e pela gelatinização do amido (Rooney \& Pflugfelder, 1986).

Os valores de digestibilidade do amido do milho floculado neste experimento são semelhantes aos valores observados por Theurer (1986), 98\% a $99 \%$ de coeficiente de digestibilidade. Galloway et al. (1993) observou efeito da moagem e da origem do grão sobre a digestibilidade do amido, em dietas à base de capim bemuda (Cynodon dactylon) de bom valor nutritivo. Esses autores observaram que o milho moído fino apresentou $92,7 \%$ de 
digestibilidade aparente do amido em comparação a $81,2 \%$ do milho fornecido inteiro. $O$ valor encontrado para o milho fornecido inteiro se assemelhou aos valores obtidos no presente experimento com a dieta contendo milho moído grosso (Tabela 14).

Os coeficientes de digestiblidade do amido apresentados pelos tratamentos S0 igual a $100 \%$, e S3 igual a $99,98 \%$ eram esperados, uma vez que estas duas dietas possuiam apenas traços de amido, facilitando a digestão total do nutriente. Galloway et al. (1993) observou também coefiente de digestiblidade de $100 \%$ para dietas apenas, com feno de capim bermuda, sem uso de suplementos.

As duas frações fibrosas, FDN e FDA, apresentaram efeito significativo do processamento do milho sobre os coeficientes de digestiblidades apresentados. O milho moído grosso elevou a digestiblidade da FDN e da FDA em relação a todos os outros tratamentos. Não houveram diferenças significativas entre o tratamento controle e os outros suplementos e nem entre suplementos (Tabela 14).

Os coeficientes de digestibilidade aparente da FDN apresentados pelos tratamentos S0, S2 e S3 (Tabela 14), foram semelhantes ao valor médio obtido por Detmann et al. (2001), que registraram um valor de 63,6\%. Entretanto, o valor apresentado pelo tratamento $S 1$, foi semelhante ao coeficiente registrado por Detmann et al. (2001), para o tratamento sem suplementação, que foi de $72,4 \%$. Valores de digestiblidade aparente para o FDN inferiores a esses foram constatados por Vanzant et al. (1990), com animais em pastejo consumindo forragem de bom valor nutritivo, e por Galloway et al (1993) com animais recebendo feno de bom valor nutricional, suplementados por grãos. Os valores registrados variaram entre 47,0 e $48,8 \%$, no experirmento realizado por Vanzant et al. (1990), e entre 50,5 e $56,7 \%$ no esutdo conduzido por Galloway et al. (1993).

A digestibilidade do FDA para os tratamentos S0, S2 e S3 encontra-se abaixo dos valores observados por Elizalde et al. (1998), 67 a $72 \%$, que se 
aproximam do valor obtido no tratamento com milho moído grosso (S1), do presente experimento. Krysl et al. (1989) encontraram coeficientes de digestiblidade para a FDN (63,7 a 66,9\%) similares e para FDA $(60,0$ a $63,0 \%)$ inferiores, aos registrados no presente experimento, e não observaram diferença significativa decorrente do uso de suplemento energético ou protéico, sobre a digestibilidade aparente da FDN e FDA.

A inclusão de carboidratos não estruturais na dieta de animais ruminantes causa depressão da digestão da fibra (Dixon \& Stockdale, 1999). Em geral, certo grau de depressão à digestão da fibra, ocorre com a inclusão de $30 \%$ ou mais, na forma de carboidratos não estruturais à dieta (Hoover 1986). Segundo Matejovsky \& Sanson (1995) o efeito da suplementação com milho na utilização da forragem por animais ruminantes, depende da dose do suplemento e do valor nutritivo da forragem. Forragem de baixa qualidade sofreu depressão linear na digestibilidade da FDN e FDA, quando níveis crescentes de milho foram adicionados à dieta, enquanto forragem de alto valor nutritivo não sofreu efeito da suplementação com níveis crescentes de milho sobre os coeficientes de digestibilidade da FDN e FDA (Matejovsky \& Sanson, 1995). Além disso, há evidências de que efeitos associativos positivos possam ocorrer, quando níveis baixos de carboidratos não estruturais são incluídos em dietas contendo forragens de baixa a média qualidade (Opatpatanakit et al. 1995), elevando o consumo de matéria seca e matéria orgânica da forragem e consequentemente da o consumo da dieta total, como foi observado por Pordomingo et al. (1991). 


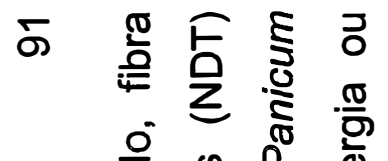

을 吾

คิ

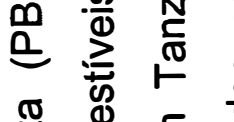

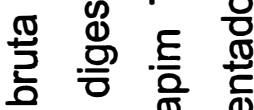

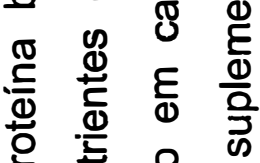

을 艺 윯 ำ

잉 \&

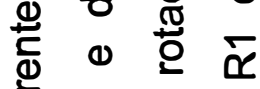

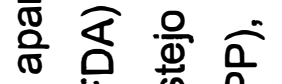

Ð

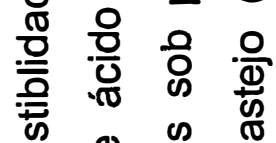

ฮั)

응 它 蛋

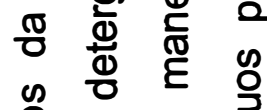

을 진 은 은

.들 은 은

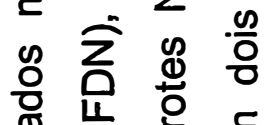

는 은

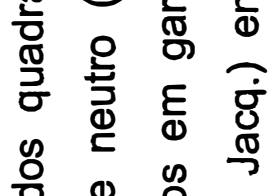

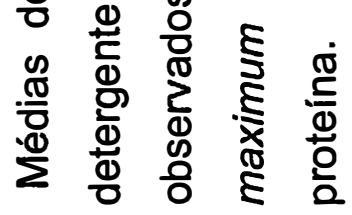

$\dot{\square}$

$\frac{\sigma}{\frac{0}{\sigma}}$

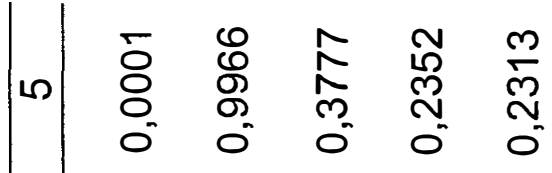

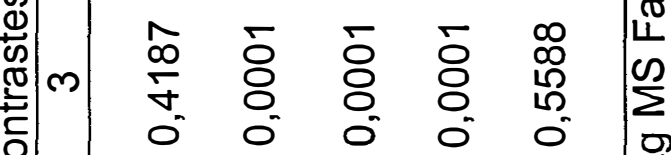

லे

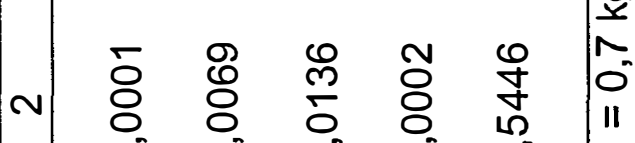

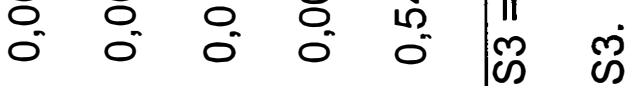

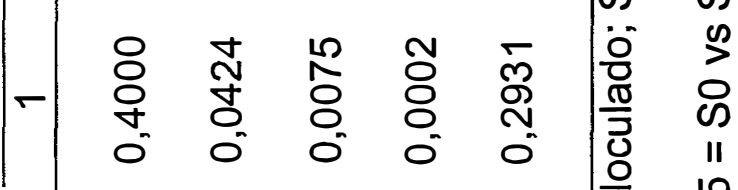

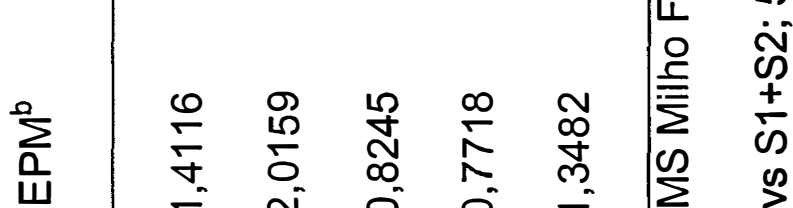

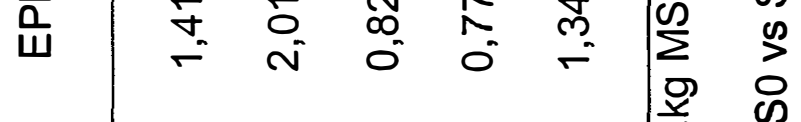

$\begin{array}{llll}2 & 0 & 0 & 0\end{array}$

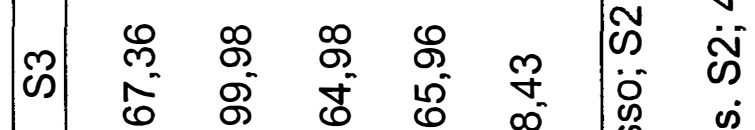

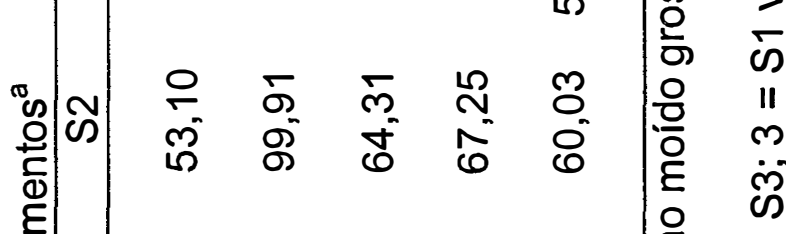

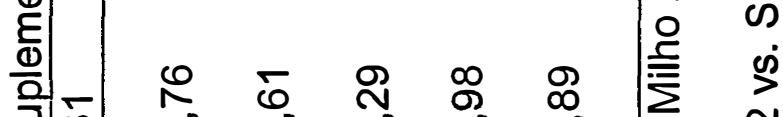

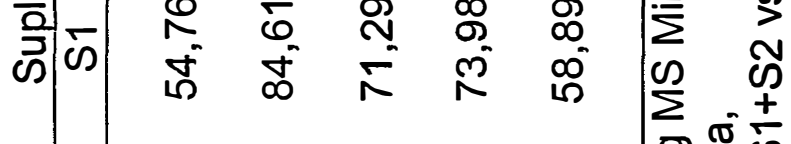

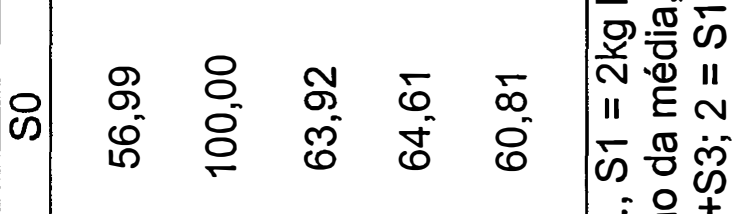

$=0$ 유 +

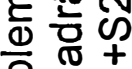

क 응

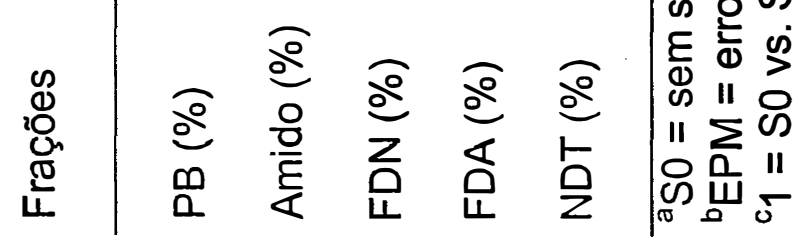


Entretanto, não houve efeito da suplementação e nem da origem do suplemento, sobre o consumo de matéria seca da forragem (Tabela 5 e Tabela 8), embora observou-se coeficientes de substituição próximos a 1 quando utilizou-se suplementos energéticos (Tabela 6). A ocorrência de coeficientes de substituição elevados, quando doses maiores de suplementos energéticos são fornecidas para os animais em pastejo sobre forragens de bom valor nutritivo, pode ser justificada pelo controle fisiológico de ingestão da matéria seca, uma vez que o efeito da inclusão de grãos sobre a redução da digestão ruminal da FDN é menos acentuado, em dietas compostas por forragem de bom valor nutritivo, como a utilizada no presente ensaio.

O uso de milho moído grosso elevou a digestiblidade das frações fibrosas da dieta (Tabela 14). Brake al. (1988), observaram o mesmo fenômeno, quando forneceram milho moído ( $0,6 \%$ do $\mathrm{PV})$ para vacas de corte, alimentadas com feno de capim bermuda (Cynodon dactylon). O coeficiente de digestibilidade foi elevado de 55,5\% (controle) para 60,6\% (suplementados). Jones et al. (1988) observaram efeito associativo positivo do suplemento à base de milho na dose de $0,3 \%$ do PV sobre a digestibiidade ruminal da FDN e FDA, embora esse fato não tenha resultado em diferenças significativas nos coeficientes de digestibilidade dessas duas frações, no trato digestivo total.

Provavelmente, uma liberação mais lenta e ao mesmo tempo cosntante do amido presente no milho moído grosso exerceu um efeito complementar sobre a demanda de substratos dos microrganismos ruminais sem prejuízo ao ambiente ruminal. Entretanto, as flutuações do $\mathrm{pH}$ ao longo do dia (Figura 1) não são suficientes para explicar um menor prejuízo ao ambiente ruminal, quando compara-se o uso de milho moído grosso ao milho floculado, pois as curvas de tendência temporal, dos dois tratamentos, dentro dos dois resíduos pós pastejo, se sobrepõem. As reduções no $\mathrm{pH}$ parecem afetar a digestão da fibra parcialmente (Hoover 1986). Outras fontes de carbono, como amido, maltose e manose, afetariam a digestibilidade da fibra ( Hoover, 1986; Haddad \& Grant, 2000), caracterizando o efeito associativo negativo decorrente 
exclusivamente de substrato, e adicional ao efeito $\mathrm{pH}$. A floculação a vapor aumenta a taxa de hidrólise do amido no rúmen (Theurer, 1986), aumentando a disponibilidade de carboidratos rapidamente fermentáveis, que atuariam diretamente reduzindo a digestibilidade da fibra, e consequentemente da matéria orgânica da dieta, uma vez que a parede celular é o maior componente da dieta estudada nesse ensaio.

\subsection{Conclusões}

A disponibilidade de matéria seca verde na pasagem é o grande limitante ao consumo de forragem por animais em pastejo sobrepondo-se à utilização de suplementos.

Deve-se estar atento ao manejo da pastagem, para que os animais tenham a sua disposição, MS de elevado valor nutritivo e em quantidades aduequadas para não limitar o consumo de forragem.

A utilização de suplementos energéticos para bovinos em pastejo, apresenta efeito mais acentuado quando a disponibilidade de matéria seca verde no dossel esteja limitando o consumo de energia digestível pelos animais. 


\section{COMPORTAMENTO INGESTIVO E SUA RELAÇÃO COM A ESTRUTURA DA PASTAGEM CONSUMIDA POR BOVINOS DE CORTE SUPLEMENTADOS COM PROTEÍNA OU ENERGIA EM PASTEJO ROTACIONADO}

\section{Resumo}

Oito garrotes da raça Nelore foram utilizados em sistema de pastejo rotacionado, com o objetivo de avaliar o comportamento ingestivo de forragem em pastagem de capim Tanzânia (Panicum maximum Jacq.), com dois niveis pré-determinados de resíduo de matéria seca após a saída dos animais. As pastagens foram manejadas para apresentar resíduos pós pastejo de $1000 \mathrm{~kg}$ de MS verde ha-1 (R1) e $4000 \mathrm{~kg}^{-1 e} \mathrm{MS}$ verde ha-1 (R2). Quatro garrotes foram colocados em cada um dos resíduos, sendo distribuídos em dois quadrados latinos $4 \times 4$, onde cada animal recebeu um tratamento de suplementação ( $S 0=$ sem suplementação; $S 1=2,24 \mathrm{~kg} \mathrm{dia}^{-1}$ de milho moído grosso, peneira de 8 $\mathrm{mm}$; $\mathrm{S} 2$ = 2,24 kg dia ${ }^{-1}$ de milho floculado; $\mathrm{S} 3=0,7 \mathrm{~kg} \mathrm{dia}^{-1}$ de farelo de soja). Os ciclos de pastejo apresentaram 33 dias de descanso e 3 dias de ocupação. Em cada periodo de pastejo foi avaliado o comportamento ingestivo dos animais por 24 horas, com observações a cada 5 minutos, durante o dia e 15 minutos durante a noite. A suplementação $(P<0,05)$ reduziu o tempo de ruminação dos animais. Os tempos de pastejo (470,63 contra 354,28 minutos dia $\left.^{-1}\right)$ e de ruminação $\left(408,48\right.$ contra 319,06 minutos dia $\left.^{-1}\right)$ foram aumentados, e o tempo em ócio foi reduzido $(p<0,05)$, para animais manejados no R2 quando comparados aos manejados no R1. Não foi observado efeito da origem do 
suplemento e da interação entre o resíduo pós pastejo de $M S$ verde $\mathrm{ha}^{-1}$ e a suplementação, sobre o comportamento ingestivo $(P>0,05)$.

Palavras chave: bovinos, pastagens, comportamento ingestivo, suplementação.

\section{FEEDING BEHAVIOR AND RELATIONSHIP WITH PASTURE STRUCTURE CONSUMED BY BEEF STEERS SUPPLEMENTED WITH PROTEIN OR ENERGY UNDER ROTATIONAL GRAZING}

\section{Summary}

Eight Nelore steers were used in a Tanzania grass (Panicum maximum Jacq.) rotational grazing system under two post grazing green dry matter (GDM) residue (1000 and $4000 \mathrm{~kg} \mathrm{ha}^{-1}$ ), three days of grazing period and 33 days of resting period, aiming to evaluate the feeding behavior. Four animals were placed on each one of the post grazing residue. Four sources of supplements (WO - no supplement; CC-2.24 kg day ${ }^{-1}$ cracked corn; SFC - $2.24 \mathrm{~kg} \mathrm{day}^{-1}$ steam flaked corn; and SBM - $0.7 \mathrm{~kg}$ day $^{-1}$ soybean meal) were used in a Latin square design. In each grazing period a $24-\mathrm{h}$ feeding behavior was evaluated, with observations every 5 minutes during the day, and every 15 minutes at night. Supplementation $(P<.05)$ reduced the rumination time of the animals. Time spent grazing (470.63 vs. 354.28 minutes day $^{-1}$ ) and ruminating (408.48 vs. 319.06 minutes day ${ }^{-1}$ ) were increased, and time spent resting was reduced $(P<$ .05) for R2 managed animals, when compared to those on R1. No significant effect from either the supplementation or the interaction between the postgrazing residue (green DM.ha' ${ }^{-1}$ ) and supplementation was noted about the feeding behavior $(P>.05)$. 
Key words: bovine, pasture, ingestive behavior, supplementation.

\subsection{Introdução}

O desempenho animal depende da ingestão diária de energia digestível, que é resultado da ingestão de matéria seca multiplicada pela concentração de energia digestível contida na matéria seca. A quantidade de forragem ingerida diariamente é produto do tempo de pastejo e da taxa de ingestão da forragem durante o pastejo. Essa taxa de ingestão é obtida através do produto entre o número de bocados por minuto e a quantidade de forragem colhida por bocado (Hodgson, 1990; Cosgrove 1997). A resposta clássica dos parâmetros de comportamento ingestivo foi demonstrada por Penning (1986) citado por Carvalho et al. (2001). Há uma relação simultânea entre a massa de forragem disponivel na pastagem e a massa apreendida pelo bocado dos animais. Quando a massa ofertada diminui, há concomitante redução na ingestão de matéria seca por bocado, o que é reflexo da condição da pastagem (Hodgson, 1990). Nessa situação, os animais aumentam o tempo de pastejo e a taxa de bocados (Hodgson 1990 e Carvalho et al. 2001). Apesar disso, o consumo diminui à medida que há diminuição no tamanho do bocado e esse não consegue ser compensado pelo aumento na frequência dos mesmos. Portanto, a massa por bocado é na maioria das vezes, o principal fator determinante da quantidade de alimento consumida por um animal em pastejo (Cosgrove 1997, Carvalho et al. 2001).

Hodgson (1990) afirmou que o tempo de pastejo é muito variável, estando dependente da disponibilidade da forragem, podendo variar de 360 a 720 minutos por dia. Krysl \& Hess (1993) detectaram, em extensa revisão da literatura, que o tempo gasto para a atividade de pastejo variou de 359 a 711 minutos por dia. Médias de tempo de pastejo com forragens tropicais foram registradas por Euclides et al. (1999), que avaliaram o comportamento de pastejo de bovinos Nelore, em recria, sobre pastagens de capim Tanzânia 
(Panicum maximum), Tobiatã (Panicum maximum) e Colonião (Panicum maximum) com disponibilidade média de $M S$ de $2060 \mathrm{~kg} \mathrm{ha}^{-1}$ no verão e 1610 $\mathrm{kg} \mathrm{ha}^{-1}$ na seca, e observaram que houve aumento significativo $(P<0,05)$ no tempo de pastejo no inverno. Os tempos de pastejo observados por Euclides et al. (1999), foram de 511 minutos por dia no verão e de 596 minutos por dia no inverno. Esses resultados demonstraram que a redução na disponibilidade de forragem no período seco do ano estimulou o aumento no tempo de pastejo. Lima et al. (2000) constataram valores de 433 minutos por dia, e 461 minutos por dia, em atividade de pastejo para vacas leiteiras em sistema rotacionado de capim Tanzânia (Panicum maximum) e capim Elefante (Pennisetum purpureum), respectivamente. Erlinger et al. (1990) observaram que novilhas de 4 grupos raciais diferentes, pastejando grama bermuda (Cynodon dactylon) sem suplementação, apresentaram tempos de pastejo que variaram de 348 a 515 minutos por dia.

O tempo de pastejo reflete a facilidade de apreensão e remoção da forragem da pastagem (Crowder \& Chheda, 1982). Tempos de pastejo superiores a 480 a 540 minutos por dia provavelmente indicarão condições limitantes da pastagem (Hodgson, 1990). Dificilmente ovinos e bovinos ultrapassam o teto de 720 minutos por dia, na atividade de pastejo (Carvalho et al. 2001).

Cosgrove (1997) afirmou que a diminuição na disponibilidade de forragem provoca aumento no tempo de pastejo, contudo, em relvados adensados, onde a taxa de ingestão é dificultada, os animais podem reduzir o tempo de pastejo pela dificuldade de apreensão da forragem. Isso foi verificado por Chacon \& Stobbs (1976), quando avaliaram o tempo de pastejo de vacas em pastagens de Setaria anceps cv. Kazungula, com diferentes disponibilidades de forragem ao longo de nove dias de observação.

Além do tempo de pastejo, o animal utiliza de 360 a 480 minutos por dia para realizar a atividade de ruminação, sendo o restante do tempo utilizado para descansar ou realizar outras atividades (Hodgson, 1990). 
O efeito do uso de suplementos sobre o comportamento de pastejo dos animais foi pouco avaliado. Alguns autores sugerem que há possibilidade de efeito do uso de concentrados sobre o tempo de pastejo de animais suplementados. Entretanto, ressalta-se que há a necessidade de se avaliar outros fatores conjuntamente ao uso de suplementos, para se obter um completo entendimento do comportamento animal nessa situação. Adams (1985) não observou efeito da suplementação com $0,3 \mathrm{~kg}$ de milho por $100 \mathrm{~kg}$ de PV, e do horário de suplementação sobre o tempo de pastejo e tempo de ruminação apresentados por bovinos em pastejo. Bonfim et al. (2000) não observaram efeito de niveis crescentes de suplemento, 0,6;0,9; 1,2 e 1,5\% do $\mathrm{PV}$, sobre o tempo de pastejo de bovinos manejados em forragem tropical sob diferimento.

No entanto, Krysl \& Hess (1993) revisaram dados avaliando a influência da suplementação no tempo de pastejo e concluíram que aumentando o nível de suplementação com grãos (amido), há redução do tempo de pastejo.

Difante et al. (2001) observaram efeito do nivel de suplemento sobre o tempo de pastejo, tempo de ruminação e tempo de ócio dos bovinos pastejando azevém (Lolium multiflorum) adubado com nitrogênio. Constataram que o uso de $0,8 \%$ do PV em milho apresentou diferença significativa sobre o tratamento sem suplemento $(P=0,0001)$, e sobre o tratamento com $0,4 \%$ do $P V$ de oferta de suplemento $(P=0,042)$, que não diferiram entre si $(P=0,104)$.

Bodine et al. (2000), avaliaram a origem do suplemento e observaram efeito significativo quando houve inclusão de milho nos suplementos oferecidos, ao nivel de $1,3 \%$ do $\mathrm{PV}$, para novilhos manejados em pastagens temperadas, com disponibilidade de MS de $3654 \mathrm{~kg} \mathrm{ha}^{-1}$ a $4353 \mathrm{~kg} \mathrm{ha}^{-1}$. O fornecimento de 0,4\% do PV em farelo de soja não afetou o tempo de pastejo.

Gekara et al. (2001) avaliaram a altura do dossel e o uso de suplementos sobre o tempo de pastejo de vacas de corte em pastagens temperadas. As amplitudes de alturas avaliadas variaram entre 4 a $8 \mathrm{~cm}$ e 8 a $11 \mathrm{~cm}$, que correspondiam ao acúmulo de $1446 \mathrm{~kg}$ de $\mathrm{MS} \mathrm{ha}^{-1}$ e $1955 \mathrm{~kg}$ de $\mathrm{MS} \mathrm{ha}^{-1}$, 
respectivamente. As quantidades de suplementos fornecidos foram 0; 3,2 e 6,4 $\mathrm{kg} \mathrm{dia}{ }^{-1}$. Os autores não observaram interação entre as quantidades de suplementos e as alturas do dossel avaliadas $(P>0,10)$. Entretanto a redução na altura do dossel elevou $(P<0,01)$ o tempo de pastejo em 72 minutos dia ${ }^{-1}$ (564 contra 492 minutos dia $^{-1}$ ). A média do tempo de pastejo demonstrada pelos animais suplementados não diferiu do tempo de pastejo do grupo controle $(p=0,1115)$. Entretanto, houve tendência de redução no tempo de pastejo dos animais que receberam $6,4 \mathrm{~kg} \mathrm{dia}^{-1}$ de suplemento, comparado ao grupo suplementado com $3,2 \mathrm{~kg} \mathrm{dia}^{-1}(P=0,0528)$. Os tempos de pastejo observados entre os níveis de suplementação foram, 546, 540 e 498 minutos dia $^{-1}$, para 0; 3,2 e $6,4 \mathrm{~kg}$ de suplemento $\mathrm{dia}^{-1}$, respectivamente.

A forma de processamento dos grãos foi avaliada por Soriano et al. (2000), que avaliaram o efeito do fornecimento de $6 \mathrm{~kg} \mathrm{dia}^{-1}$ de milho ensilado com alta umidade ou $6 \mathrm{~kg} \mathrm{dia}^{-1}$ de milho moído grosso para vacas leiteiras. Não observaram efeito do tipo de suplemento sobre o tempo de pastejo dos animais, que foi de 384 minutos dia $^{-1}$.

A estrutura e a composição botânica da pastagem pode exercer um efeito direto sobre a ingestão de forragem por animais em pastejo, independente da influência da composição química e do conteúdo de nutrientes da própria forragem (Hodgson, 1990). Segundo Erlinger et al. (1990), a relação planta animal é um complexo sistema de interações quando os animais estão em contato direto com a forragem no campo. Sempre que se abordam estas relações, entre a estrutura da pastagem e o comportamento de pastejo dos animais, questiona-se a carência de informações em pastagens tropicais. Os trabalhos conduzidos por Stobbs (1973a) e Stobbs (1973b) indicam que, em pastagens tropicais, a densidade volumétrica e a relação folha colmo ${ }^{-1}$ teriam importância mais relevante na determinação do comportamento ingestivo dos animais, quando comparadas às pastagens temperadas.

O objetivo deste trabalho foi o de avaliar o efeito da disponibilidade de forragem e da suplementação sobre o comportamento de pastejo de bovinos 
manejados em sistema de pastejo rotacionado.

\subsection{Material e métodos}

\subsubsection{Instalações experimentais e animais}

O experimento foi realizado na fazenda Areão da ESALQ/USP em uma área de 6 hectares estabelecida com capim Tanzânia (Panicum maximum Jacq. Cv. Tanzania) sob irrigação com equipamento do tipo pivô central, subdividida em quatro blocos. Cada bloco foi composto por um conjunto de seis piquetes, com três piquetes para cada resíduo de pastejo, perfazendo um total de 24 subdivisões, com $1500 \mathrm{~m}^{2}$ cada, divididas por cercas fixas e/ou eletrificadas. Cada resíduo de pastejo testado foi dividido em 12 piquetes. O manejo adotado para o sistema constitui-se em um intervalo de descanso de 33 dias, com três dias de ocupação para cada piquete. A forragem recebeu fertilização na dose de $334 \mathrm{~kg} \mathrm{ha}^{-1}$ da fórmula 24-04-24 (80 kg de $\mathrm{N} \mathrm{ha}^{-1}$ ) para cada ciclo de pastejo, logo após a saída dos animais.

Foram utilizados oito garrotes da raça Nelore, com peso vivo médio de $306,6 \mathrm{~kg}$, divididos em dois grupos de quatro animais cada, em um delineamento experimental contendo dois quadrados latinos $4 \times 4$, um para cada resíduo de pastejo estudado. Em cada quadrado latino foram testados quatro formas de suplementação. Os animais utilizados neste experimento sofreram adaptação prévia às instalações e à cirurgia de implantação das cânulas no rúmen e no duodeno proximal.

\subsubsection{Tratamentos}

Um grupo de quatro animais permaneceu durante o período experimental em doze piquetes rotacionados, manejados para atingirem resíduo pós pastejo de $1000 \mathrm{~kg}$ de matéria seca verde ha-1 (R1), enquanto o outro grupo de quatro 
animais permaneceu em doze piquetes rotacionados, manejados com o objetivo de atingir $4000 \mathrm{~kg}$ de matéria seca verde $\mathrm{ha}^{-1}(\mathrm{R} 2)$, de resíduo pós pastejo (Penati, 2002). Os quatro animais utilizados em cada tratamento de resíduo pós pastejo, foram mantidos juntamente com outros animais chamados de traçadores, que entravam e saíam dos piquetes, com o objetivo de obter-se os resíduos pós pastejo desejados. A cada intervalo de 33 dias os animais retornavam ao piquete inicial do sistema.

Em cada resíduo pós pastejo haviam quatro tratamentos de suplementação:

SO - Controle, sem suplementação (SS)

$\mathrm{S} 1$ - 2,24 $\mathrm{kg} \mathrm{dia}^{-1}$ de milho moído grosso em peneira de $8 \mathrm{~mm}$ (MMG)

S2 - 2,24 kg dia-1 de milho floculado $\left(360{\mathrm{~g} . \mathrm{L}^{-1}}^{-1}\right)(\mathrm{MF})$

$\mathrm{S} 3-0,8 \mathrm{~kg} \mathrm{dia}^{-1}$ de farelo de soja (FS)

O milho floculado preparado pela Cia Sul Mineira, Varginha-MG, se submeteu aos ajustes de equipamento visando intensidade de processamento físico necessário para obter-se densidade final de $360 \mathrm{~g} \mathrm{~L}^{-1}$.

As quantidades de suplementos energéticos ofertadas foram compativeis com a expectativa de disponibilidade da fração nitrogenada proveniente da pastagem, para garantir um desempenho estimado de ganho ao redor de $1,2 \mathrm{~kg}$ $\mathrm{dia}^{-1}$ e 1,3 $\mathrm{kg} \mathrm{dia}^{-1}$ respectivamente, para os tratamentos S1 e S2 (NRC, 1996). No caso do tratamento S4, a oferta adicional de farelo de soja, simulou a possibilidade de amplificação da síntese de proteína microbiana, com a elevação da disponibilidade de uma fonte de proteína de maior taxa de degradação ruminal, atingindo níveis mais elevados de proteína dietética e amônia ruminal.

Os suplementos foram fornecidos duas vezes ao dia em quantidades iguais (50\% do total pela manhã e $50 \%$ à tarde), em torno das 7 e 16 horas, através da cânula ruminal para garantir que toda a quantidade de suplemento 
fosse ingerida. Os animais tinham livre acesso a misturas minerais colocadas em cochos próprios disponíveis em cada piquete de pastejo.

\subsubsection{Período experimental}

Um período pré-experimental de 5 meses, foi necessário para amansar os animais e realizar as cirurgias, e a completa recuperação dos animais no período pós cirúrgico.

O período experimental teve duração de 50 dias, iniciando no dia 05/12/1999 e encerrando dia 24/01/2000. Este período foi subdividido em 4 subperíodos, de 12 a 13 dias de extensão, com 8 a 9 dias de adaptação e 4 dias de coleta de conteúdo ruminal. A variação no período de adaptação ocorreu em função das condições metereológicas que permitissem o manejo dos animais.

\subsubsection{Avaliação do comportamento de pastejo e da estrutura do dossel}

As observações para obtenção dos dados sobre o comportamento de pastejo dos oito animais foram conduzidas por 6 observadores treinados. Esses observadores trabalharam em duplas, com turnos de observação de 8 oito horas. Os observadores foram posicionados em torre móvel, protegida lateralmente e no teto, e localizada a 3,5 metros acima do solo, com ângulo de visão de $360^{\circ}$.

As observações foram realizadas no sexto e sétimo dia ou sétimo e oitavo dia do período de adaptação, iniciando-se a avaliação do comportamento ingestivo dos animais, com 24 horas ininterruptas de avaliação, das12 horas de um dia às 11:55 horas do dia seguinte.

Durante as 24 horas, os animais foram observados a cada cinco minutos, com o auxílio de binóculo de visão diurna (Zenith $10 \times 50$ Field $5^{\circ}$ ), durante o 
periodo de iluminação solar; enquanto à noite, as observações foram realizadas a intervalos de quinze minutos com a utilização de binóculo de visão noturna (Night Vision Binoculars, modelo BN 356, Newcon, $\mathrm{OH}$, USA). O período noturno foi considerado das 20 horas às 6:10 horas do dia subsequente.

Cada animal foi identificado com tinta preta em várias partes do corpo. Nessas observações foram anotados os seguintes comportamentos: tempo de pastejo, tempo de ruminação e ócio. O tempo utilizado pelos animais para ingestão de água e sal mineral foi considerado como ócio.

Os dados sobre a estrutura do dossel, antes da entrada dos animais e após a saída dos mesmos dos piquetes foram tomados de acordo com a metodologia descrita por Penati (2002).

\subsubsection{Análise estatística}

Adotou-se o delineamento tipo quadrado latino $4 \times 4$, com um quadrado latino para cada resíduo pós pastejo. Adotou-se o nivel de significância de $5 \%$ a fim de detectar diferença estatística na análise de variância. Quando a análise detectou efeito significativo da suplementação sobre o comportamento de pastejo as médias foram comparadas através dos seguintes contrastes:
a) $\mathrm{S} 0$ vs $\mathrm{S} 1+\mathrm{S} 2+\mathrm{S} 3$
b) $S 3$ vs $S 1+S 2$
c) $S 1$ vs $S 2$
d) $\mathrm{SO}$ vs $\mathrm{S} 1+\mathrm{S} 2$
e) $\mathrm{SO}$ vs $\mathrm{S3}$

Para análise da variância foi utilizado o procedimento GLM do programa SAS (1991). As médias foram obtidas através dos quadrados mínimos, utilizando o comando LSMEANS do programa SAS (1991). O quadro da análise de variância proposto consta na Tabela 1. Como não houve interação entre 
resíduo pós pastejo e suplementos, essa causa de variação foi retirada do modelo.

Tabela 1. Esquema de análise da variância para o ensaio de comportamento de pastejo.

\begin{tabular}{lc}
\hline Causas de variação & Graus de liberdade \\
\hline Quadrado Latino (QL) & 1 \\
Animais (QL) & 6 \\
Suplementos & 3 \\
Período & 3 \\
Resíduo & 18 \\
Total & 31 \\
\hline
\end{tabular}

\subsection{Resultados e discussão}

\subsubsection{Tempo de pastejo}

Os dados referentes aos tempos de pastejo (minutos dia $^{-1}$ ) observados em cada resíduo pós pastejo constam na tabela 2, encontrando-se dentro da amplitude sugerida por Hodgson (1990) e Krysl \& Hess (1993), que varia entre 359 a 720 minutos dia $^{-1}$. Houve efeito significativo do resíduo pós pastejo sobre o tempo de pastejo $(P<0,05)$.

Não houve efeito significativo da suplementação sobre o tempo de pastejo ( $P>0,05$ ) apresentado pelos animais (Tabela 2 ), concordando com as observações de Adams (1985) que não encontrou efeito da suplementação energética (0,3 kg de milho por $100 \mathrm{~kg}$ PV por dia) sobre o tempo de pastejo de garrotes de corte. Esses autores também não observaram efeito do horário de suplementação sobre o tempo de pastejo dos animais. Ressalta-se que as avaliações realizadas por Adams (1985) foram realizadas com gramíneas temperadas. Bonfim et al. (2000) avaliaram o efeito de quatro níveis de concentrado, como suplemento, para pastagens tropicais diferidas no período seco $(0,6 ; 0,9 ; 1,2$ e $1,5 \%$ do $P V)$, e não observaram efeito da suplementação concentrada $(P>0,05)$ sobre o tempo de pastejo de novilhos mestiços que 
variou entre 315 e 386 minutos $\mathrm{dia}^{-1}$.

Tabela 2. Médias dos quadrados mínimos para os tempos de pastejo, de ruminação e de ócio (minutos $\mathrm{dia}^{-1}$ ); provenientes de garrotes manejados sob pastejo rotacionado em capim Tanzânia (Panicum maximum Jacq.) em dois resíduos pós pastejo (R1 e R2), recebendo suplementação protéica ou energética.

\begin{tabular}{|c|c|c|c|c|c|}
\hline & \multirow[t]{2}{*}{$\mathrm{R} 1^{\mathrm{c}}$} & \multirow[t]{2}{*}{$\mathrm{R} 2$} & \multirow[t]{2}{*}{$\mathrm{EPM}^{\mathrm{a}}$} & \multicolumn{2}{|c|}{ Efeitos Principais ${ }^{d}$} \\
\hline & & & & RPP & SUP $^{\mathrm{D}}$ \\
\hline Tempo de pastejo & 354,38 & 470,63 & 19,19 & 0,0007 & 0,7826 \\
\hline Tempo de ruminação & 319,06 & 408,48 & 11,80 & 0,0001 & 0,0435 \\
\hline Tempo em ócio & 766,56 & 560,63 & 24,90 & 0,0001 & 0,4387 \\
\hline
\end{tabular}

Os tempos de pastejo obtidos pelos animais submetidos ao menor resíduo-alvo pós pastejo (R1) que apresentou menor disponibilidade de folhas (Tabela 3), encontram-se dentro dos valores apresentados por Bonfim et al. (2000). Essa semelhança explica-se porque Bonfim et al. (2000) avaliaram o comportamento de pastejo no período seco do ano, em pastagens que provavelmente apresentaram limitação de forragem para o pastejo, semelhante ao observado no R1. Os tempos de pastejo apresentados pelos animais submetidos ao resíduo R2, encontram-se próximos aos observados por Adams (1985), que registrou tempos de pastejo variando entre 438 e 540 minutos dia ${ }^{-1}$ para animais suplementados e 504 minutos $\mathrm{dia}^{-1}$, para o grupo não suplementado.

O tempo de pastejo dos animais que não foram suplementados no R2 
(Tabela 3) foi próximo ao valor obtido por Euclides et al. (1999), para novilhos Nelore pastejando capins do gênero Panicum (Colonião, Tobiatã e Tanzânia) manejados sob lotação contínua no verão. Entretanto, no resíduo (R1), devido à menor disponibilidade de matéria seca verde, o tempo de pastejo registrado demonstrou-se muito abaixo daquele reportado por Euclides et al. (1999) que foi de 511 minutos dia $^{-1}$. Erlinger et al. (1990) observaram tempo de pastejo variável para animais pastejando grama bermuda (Cynodon dactylon) sem suplementação. Estes autores observaram amplitude no tempo de pastejo variando entre 348 a 515 minutos dia ${ }^{-1}$. Ribeiro Filho et al. (1999) observaram tempo de pastejo superior aos observados nesse estudo, para bovinos manejados em pastagens de capim elefante. O tempo de pastejo médio registrado por Ribeiro Filho et al. (1999) foi de 541 minutos dia ${ }^{-1}$. 


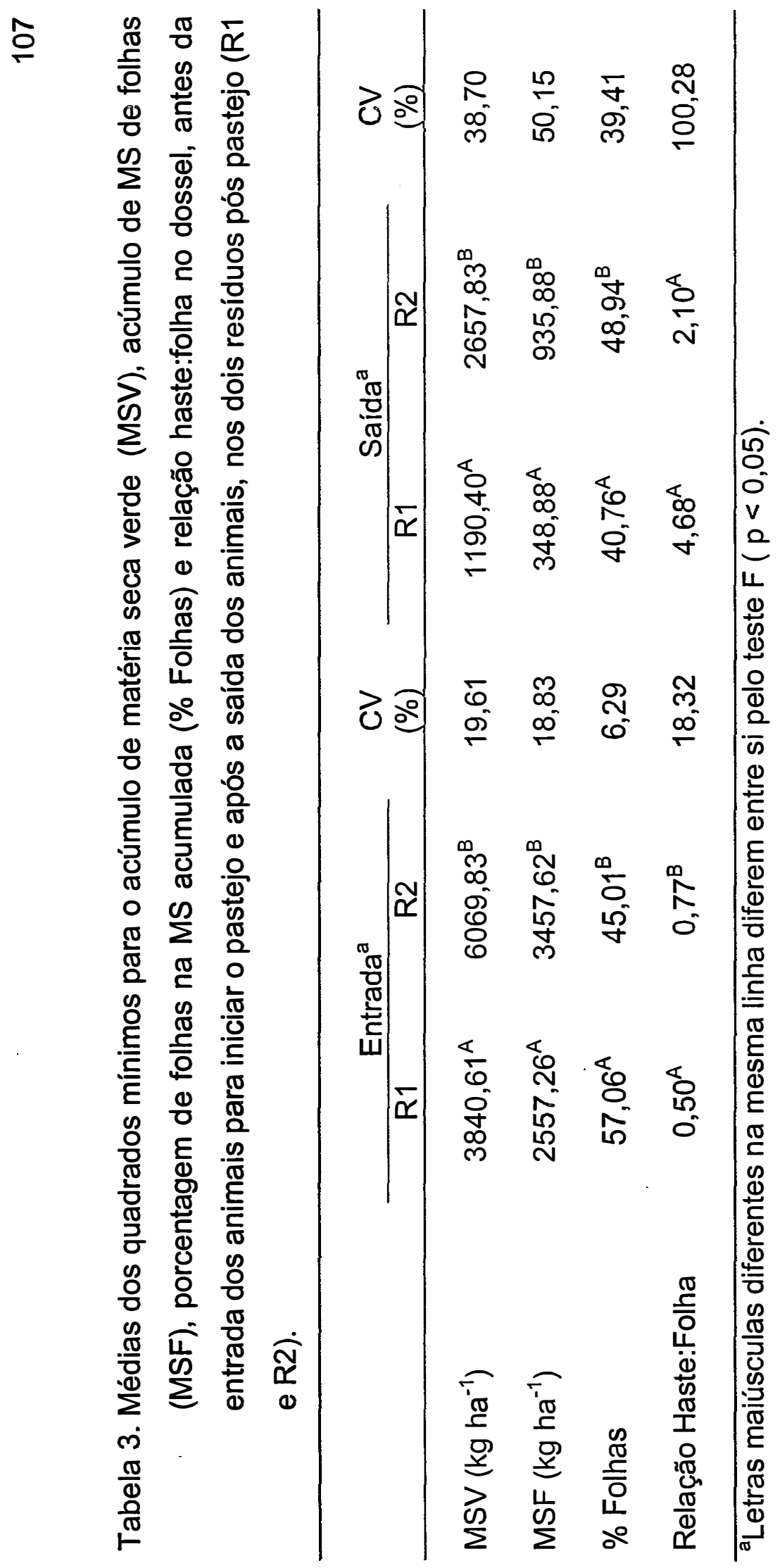


A ausência de efeito do fornecimento de suplemento aos animais sobre o tempo de pastejo, explica-se pelo fato de que não houve efeito da suplementação sobre o consumo de matéria seca da forragem (Tabela 5 capitulo 3). Os animais suplementados provavelmente reduziram a taxa de bocados ou o tamanho do bocado embora tenham demonstrado o mesmo tempo de pastejo. Krysl \& Hess (1993) demonstram em que em algumas situações, os animais suplementados não reduzem o tempo de pastejo mas reduzem a intensidade do pastejo. Esses autores relataram que o pastejo intenso muitas vezes é substituido pelo pastejo exploratório. Segundo Barton et al. (1992) o pastejo intenso caracteriza-se por vários bocados na mesma touceira, sem o animal se mover, enquanto que o pastejo exploratório é caracterizado pela frequente movimentação dos animais de um lugar ao outro, com poucos bocados a cada novo local de movimentação. Entretanto no presente ensaio não foram avaliadas as formas de pastejo.

Krysl \& Hess (1993) ao realizarem extensa revisão sobre o efeito da suplementação sobre o comportamento de pastejo de bovinos, observaram que geralmente a utilização de grãos (amido) como suplemento reduziu o tempo de pastejo. Bodine et al. (2000) também observaram efeito da suplementação sobre o tempo de pastejo. Esses autores utilizaram o milho como matéria prima básica, fornecido ao nivel de $1,3 \%$ do peso vivo, exclusivamente ou misturado ao farelo de soja, e verificaram redução no tempo de pastejo de bovinos em pastagens temperadas, com disponibilidade de matéria seca variando entre 3654 e $4353 \mathrm{~kg}$ de $\mathrm{MS} \mathrm{ha}^{-1}$. Entretanto, nesse mesmo trabalho os autores mencionam que foi difícil separar os efeitos da origem e do nível de concentrado administrado, uma vez que foi fornecido um terceiro tipo de suplemento, que foi $0,4 \%$ do PV de farelo de soja. No entanto Bodine et al. (2000) observaram que a utilização dos suplemento contendo milho reduziu o tempo de pastejo e a intensidade de pastejo, provavelmente não acompanhada por pastejo exploratório.

O efeito do nivel de concentrado foi estudado por Difante et al. (2001), 
que observaram redução no tempo de pastejo de bovinos em pastagens cultivadas de azevém, recebendo níveis crescentes de milho moído como forma de suplemento. Gekara et al. (2001) também avaliaram o nível de suplemento $\left(0,3,2\right.$ e $\left.6,4 \mathrm{~kg} \mathrm{vaca}^{-1} \mathrm{dia}^{-1}\right)$ sobre o comportamento de vacas de corte em pastejo. Não houve diferença significativa entre o grupo controle e a média dos grupos suplementados, embora os autores tenham observado tendência $(p=$ 0,0528) de redução no tempo de pastejo apresentado pelos animais que receberam níveis maiores de suplemento, quando comparado ao nível mais baixo. Gekara et al. (2001) também avaliaram duas alturas de resíduos póspastejo, e a interação entre altura de resíduo pós pastejo e quantidade de suplemento. Não foram encontrados efeitos significativos $(P>0,10)$ para interação. Esses resultados concordam com os observados no presente experimento (Tabela 2). Entretanto, Gekara et al. (2001) observaram aumento no tempo de pastejo de vacas de corte em lactação, quando a altura da dossel foi menor, reduzindo a disponibilidade de forragem.

Pela comparação dos resultados apresentados nas tabelas 2 e 3 observou-se que além da redução na disponibilidade de matéria seca verde do resíduo pós pastejo $\mathrm{R} 1$, houve alteração na composição morfológica do mesmo, com redução no tempo de pastejo dos garrotes $(P<0,05)$. Fato que contrapõe os resultados obtidos por Euclides et al. (1999), que avaliaram três cultivares de Panicum maximum, e constataram aumento no tempo de pastejo médio de 511 contra 596 minutos dia $^{-1}$ quando a disponibilidade média de MS da pastagem foi reduzida de $2060 \mathrm{~kg} \mathrm{ha}^{-1}$ no verão para $1610 \mathrm{~kg} \mathrm{ha}^{-1}$ no inverno, com diminuição na participação de folhas no dossel. Aumento na taxa de lotação demonstrou aumento $(P<0,05)$ no tempo de pastejo de novilhos de 522 para 609,5 minutos dia ${ }^{-1}$ (Ackerman et al. 1998).

A explicação mais provável para a redução no tempo de pastejo, apresentado pelos animais manejados no tratamento onde o objetivo foi a obtenção de $1000 \mathrm{~kg}$ de MS verde ha-1 (R1), reside no fato de que foi mínima a quantidade de folhas presentes na pastagem, após o primeiro dia de pastejo 
(dados não publicados), prejudicando assim a apreensão da forragem pelos animais. Dessa forma, houve inibição da atividade de pastejo pelos animais, havendo assim, maior tempo de procura de forragem nos piquetes ou pastejo de pontas de hastes, estrutura da planta de difícil apreensão e corte. Essa explicação encontra apoio na revisão realizada por Cosgrove (1997), que afirmou que em relvados de altura reduzida, onde a taxa de ingestão é dificultada, os animais podem reduzir o tempo de pastejo. Fato também observado por Chacon \& Stobbs (1976), quando avaliaram o tempo de pastejo de vacas em pastagens de Setaria anceps cv. Kazungula. Segundo esses autores, a redução do tempo de pastejo em pastagens com baixa disponibilidade de forragem, explica-se pela relutância dos animais em selecionar pequena quantidade de folhas das hastes e das porções contaminadas por dejetos dos animais. Situação semelhante foi observada no presente experimento, em que no tratamento R1 a quantidade de matéria seca verde, antes da entrada, e após a saida dos animais, apresentou-se menor que a quantidade de matéria seca verde mensurada no tratamento $\mathrm{R} 2$, nas mesmas épocas. Além disso, o tratamento R1 apresentou menor porcentagem de folhas no resíduo, após as 72 horas de ocupação do piquete, originando valores muito baixos de disponibilidade de folhas ( $\mathrm{kg} \mathrm{ha}^{-1}$ ) no tratamento R1, após a saída dos animais (Tabela 4). Esse fato, aliado ao posicionamento das folhas próximo ao solo, em função da estrutura da planta forrageira, que foi moldada à maior pressão de pastejo aplicada no R1, dificultou a seleção e a apreensão da forragem pelo animal.

Outra forma de explicar a redução no tempo de pastejo dos animais submetidos ao R1 foi mencionada por Jamieson \& Hodgson (1979). Esses autores propuseram que a redução no tempo de pastejo em sistemas rotacionados, com baixa disponibilidade de forragem, pode ser um comportamento adquirido, onde os animais ponderam a dificuldade de apreensão da forragem com a antecipação de serem removidos a um novo piquete. Segundo Cosgrove (1997) há ainda um grande componente 
comportamental inexplicado, concordando com os registros obtidos nesse experimento, onde observou-se que, no último dia de ocupação dos piquetes, os animais posicionavam-se próximos às porteiras, à espera da mudança para novos piquetes.

Entretanto quando calculamos a eficiência de colheita ( $g$ de MS de forragem $\mathrm{kg} \mathrm{PV}^{-1}$ minutos de pastejo ${ }^{-1}$ ) para os animais submetidos aos dois resíduos pós pastejo, observa-se que embora os animais submetidos ao R1 tenham reduzido o tempo de pastejo pela baixa disponibilidade de forragem a eficiência de colheita foi um pouco superior $(0,058$ contra $0,046 \mathrm{~g}$ de MS de forragem $\mathrm{kg} \mathrm{PV}^{-1}$ minuto de pastejo-1). Entretanto esses valores não sofreram análise estatística. A maior eficiência de colheita apresentada pelos animais submetidos ao R1 explica-se pela intensidade de pastejo mais elevada no primeiro dia de ocupação dos piquetes, momento em que havia abundância de folhas na área. A maior eficiência de pastejo juntamente com os menores tempos de pastejo registrados para os animais do $\mathrm{R} 1$, reduzem o custo energético para realização do pastejo (Barton et al. 1992; Krysl \& Hess 1993), atenuando possíveis diferenças de desempenho causadas pela menor ingestão de matéria seca da forragem, pelos animais submetidos a esse resíduo pós pastejo.

\subsubsection{Tempo de ruminação e tempo em ócio}

Os tempos de ruminação (minutos dia $^{-1}$ ) e de estado de ócio (minutos dia $^{-1}$ ) encontram-se na Tabela 2. Os resíduos de matéria seca verde (R1 e R2) apresentaram influência sobre essas duas variáveis comportamentais. Houve redução no tempo de ruminação e aumento no tempo em ócio $(P<0,05)$, quando os animais foram expostos ao tratamento R1, que apresentava a menor disponibilidade de forragem. Isso pode ser explicado pelo menor tempo de pastejo observado nos animais submetidos a um menor resíduo de matéria seca verde no R1 (Tabela 3), que inibiu a atividade de pastejo, originando 
menor ingestão de matéria seca da forragem por esses animais (Tabela 5 capítulo 3), reduzindo a quantidade de forragem destinada a ruminação.

Para o tempo de ruminação houve efeito significativo $(P<0,05)$ do uso de suplementos (Tabela 2). A suplementação reduziu o tempo de ruminação (Tabela 4), entretanto, não houve interação entre suplementação e residuo pós pastejo ( $P=0,1162$ ). $O$ efeito de diluição causado pelo fornecimento do concentrado sobre o consumo de FDN, provavelmente reduziu o tempo de ruminação demonstrado pelos animais suplementados. Não houve efeito significativo da origem do suplemento $(P>0,05)$ sobre o tempo de ruminação (Tabela 4).

Adams (1985) não observou diferença entre os tempos de ruminação de bovinos de corte suplementados com milho e sem suplementação. $O$ tempo de ruminação registrado por Adams (1985) foi de 420 minutos dia $^{-1}$, tanto para os animais suplementados quanto para os não suplementados. Esse tempo se assemelha a média observada no $R 2$, que foi superior $(P<0,05)$ ao valor médio obtido no menor resíduo de pastejo (R1) (Tabela 2). Entretanto, o nível de suplemento, à base de milho, fornecido para animais em pastejo, exerceu efeito significativo sobre o tempo de ruminação (Difante et al. 2001). Esses mesmos autores verificaram redução no tempo de ruminação e aumento no tempo em ócio, quando os animais receberam $0,8 \%$ do PV em concentrado comparado ao grupo sem suplementação e com $0,4 \%$ do PV de oferta de suplemento. 


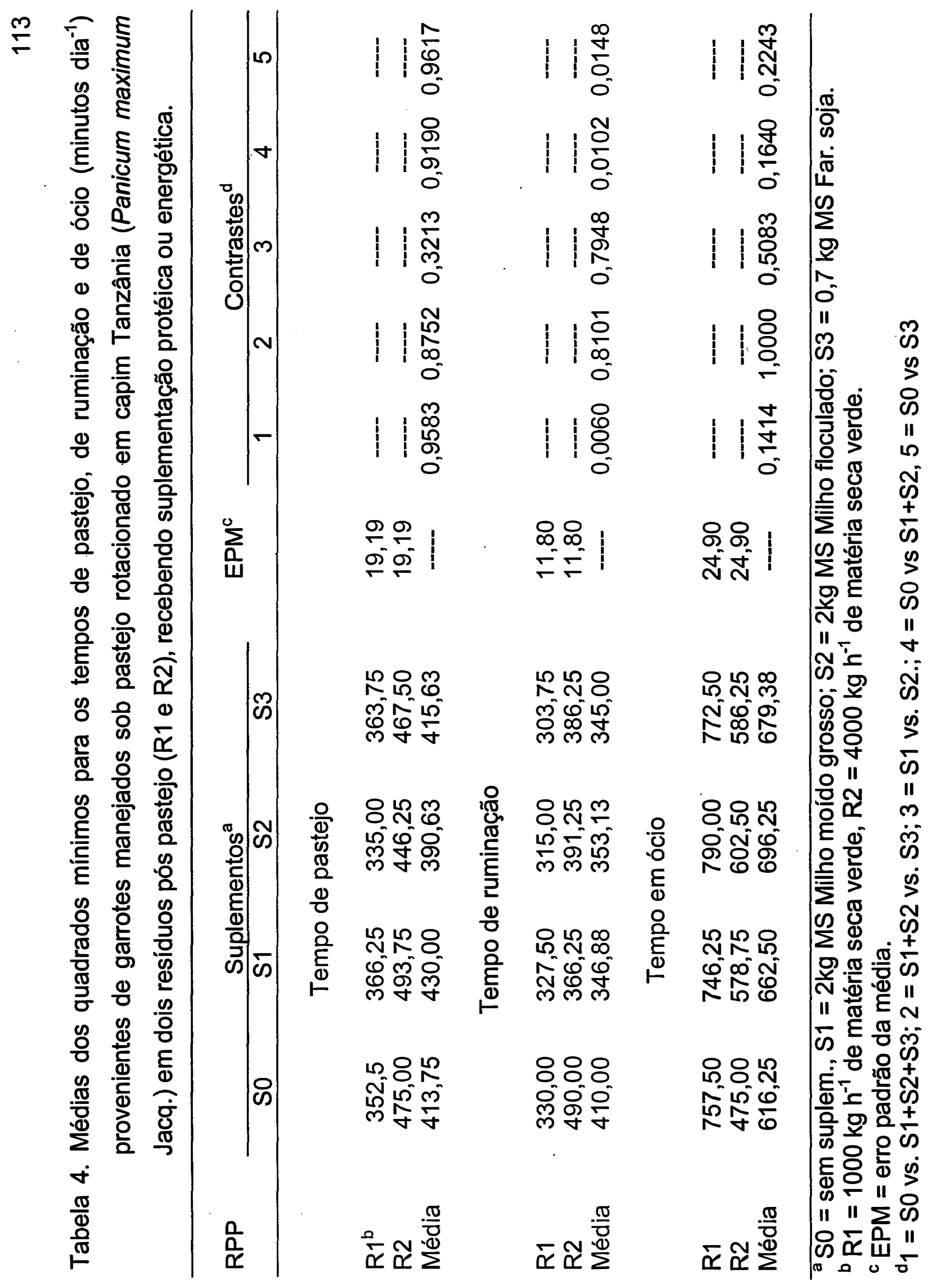


O tempo em ócio observado no presente experimento, não foi alterado significativamente $(P>0,05)$ pela suplementação (Tabela 2 ), fato que contraria as observações realizadas por Difante et al. (2001). Apenas os resíduos de forragem, após a saída dos animais, demonstraram ter efeito significativo ( $P<$ 0,05 ) sobre o tempo em que os animais permaneceram em ócio (Tabela 2). Da mesma forma Adams (1985) não observou efeito do suplemento sobre o tempo em ócio dos animais. O maior tempo em ócio apresentado pelos animais do tratamento R1 é explicado pelos menores tempos de pastejo e consequentemente de ruminação.

Os tempos de ruminação e os tempos em ócio obtidos nesse experimento (Tabela 2) encontram-se abaixo e acima, respectivamente, dos valores constatados por Difante et al. (2001), que obtiveram tempos de ruminação de 514, 471 e 461 minutos dia $^{-1}$ e tempo em ócio de 507, 555 e 612 minutos dia $^{-1}$, para animais sem suplemento, e para os que receberam $0,4 \mathrm{e}$ $0,8 \%$ do PV em milho, respectivamente.

\subsection{Conclusões}

A disponibilidade de matéria seca verde, e de matéria seca de folhas, influenciou o comportamento de pastejo de bovinos em sistemas rotacionados. A redução nos tempos de pastejo e de ruminação, e o aumento no tempo em ócio, demonstra a importância da oferta de forragem para garantir comportamento ingestivo adequado pelos animais. O uso de suplementação não alterou o tempo de pastejo e o tempo em ócio, mas diminuiu o tempo de ruminação em função do menor consumo de parede celular (FDN) causado pelo consumo do concentrado. Assim infere-se que a disponibilidade de forragem na pastagem exerce efeito mais acentuado sobre o comportamento ingestivo de bovinos em pastejo que a prática da suplementação. 


\section{EFEITO DA SUPLEMENTAÇÃO ENERGÉTICA OU PROTÉICA SOBRE A DEGRADABILIDADE RUMINAL DO CAPIM TANZÂNIA (Panicum maximum Jacq. cv. Tanzânia ) MANEJADO SOB DOIS RESÍDUOS PÓS PASTEJO, EM SISTEMA ROTACIONADO DE PASTEJO, NO VERÃO.}

\section{Resumo}

Oito garrotes da raça Nelore foram utilizados em um sistema de pastejo rotacionado, em capim Tanzânia (Panicum maximum Jacq.), apresentando dois niveis de resíduo de matéria seca verde (MSV) após a saída dos animais (R1 = $1000 \mathrm{~kg} \mathrm{ha}^{-1}$ de MSV e R2 = $4000 \mathrm{~kg} \mathrm{ha}^{-1}$ de MSV). Quatro garrotes foram colocados em cada um dos resíduos, sendo distribuídos em dois quadrados latinos $4 \times 4$, onde cada animal recebeu um tratamento de suplementação (S0 = sem suplementação; $\mathrm{S} 1=2,24 \mathrm{~kg} \mathrm{dia}^{-1}$ de milho moído grosso, peneira de 8 $\mathrm{mm} ; \mathrm{S} 2=2,24 \mathrm{~kg} \mathrm{dia}^{-1}$ de milho floculado; $\mathrm{S} 3=0,7 \mathrm{~kg} \mathrm{dia}^{-1}$ de farelo de soja). Os ciclos de pastejo apresentaram 33 dias de descanso e 3 dias de ocupação. Não houve efeito da suplementação sobre os parâmetros de degradabilidade ruminal da matéria seca, fibra em detergente neutro e fibra em detergente ácido $(P>0,05)$. O resíduo de matéria seca verde pós pastejo influenciou apenas a fração insolúvel e potencialmente degradável da FDN e FDA, que foram superiores para o R1 $(P<0,05)$ e a taxa fracional de degradação da FDN que foi menor para o R1 $(P<0,05)$. Não ocorreram diferenças significativas entre os parâmetros de degradabilidade ruminal da matéria seca das forragens colhidas nos dois resíduos pós pastejo avaliados $(P>0,05)$, apesar de haver superioridade para a degradabilidade da fração fibra no R2. 
Palavras chave: bovinos, suplementação, forragem, degradabilidade ruminal, fibra.

ENERGY OR PROTEIN SUPPLEMENT EFFECTS ON RUMEN DEGRADABILITY IN BEEF CATTLE ROTATIONALLY GRAZING TANZANIA GRASS, UNDER TWO POST GRAZING RESIDUES DURING SUMMER

\section{Summary}

Eight Nelore steers were used in a Tanzania grass rotational grazing system under two post grazing green dry matter (GDM) residue (1000 and 4000 $\mathrm{kg} \mathrm{ha}^{-1}$ ), three days of grazing period and 33 days of resting period. Four animals were allocated to each one of the post grazing residue. Four sources of supplements (WO - no supplement; CC -2.24 kg day ${ }^{-1}$ cracked com; SFC - 2.24 $\mathrm{kg} \mathrm{day}^{-1}$ steam flaked corn and SBM $-0,7 \mathrm{~kg} \mathrm{day}^{-1}$ soybean meal) were used in a Latin square design. There were no differences in rumen dry matter, FDN and FDA degradabilities due to supplements. Animals kept in the lowest post grazing residue treatment showed a higher $(P<.05)$ insoluble and potentially degradable FDN and FDA and a lower $(P<.05)$ FDN degradation rate as compared to the animals having a lower forage availability. Rumen dry matter degradability was the same for both post grazing residue treatments.

Key words: bovine, supplement, forage, ruminal degradability, fiber

\subsection{Introdução}

O rúmen é o local de maior ocorrência de digestão da fibra no sistema 
digestivo dos ruminantes (Van Soest, 1994). Sendo as forragens tropicais as mais fibrosas, com $60 \%$ a $75 \%$ de parede celular na matéria seca, a digestão ruminal da matéria seca é dependente da digestão da fibra no rúmen (Dixon \& Stockdale, 1999).

Segundo Mertens (1997) a fibra pode ser definida nutricionalmente como sendo a fração lentamente digestível ou a fração indigestível dos alimentos que ocupam espaço físico no trato gastrointestinal dos animais. A porção fibra dos alimentos é formada por carboidratos estruturais, que são representados pela fração fibra detergente neutro (FDN), e essa apresenta uma relação inversamente proporcional à densidade energética. Porém, há necessidade de uma quantidade mínima de fibra de boa qualidade, para promover máximo consumo de matéria seca e energia, manter a fermentação ruminal e prevenir distúrbios metabólicos nos animais (Hoover 1986; NRC, 1989).

A digestão da fibra no rúmen é um processo dinâmico que envolve a aderência e a fermentação dos polissacarídeos da parede celular pelos microrganismos. A extensão da digestão da fibra é caracterizada pela proporção de fibra potencialmente digestível, e das taxas de digestão e de passagem no rúmen (Allen \& Mertens, 1988). A taxa e a extensão da digestão dos carboidratos estruturais são comprometidas pela queda acentuada do $\mathrm{pH}$, decorrente da maior produção de ácidos orgânicos durante a fermentação de carboidratos não estruturais, que estimulam o aumento da taxa de crescimento de bactérias não celulolíticas, que devem competir com vantagens sobre as bactérias celulolíticas, resultando em menor degradação da parede celular (Fahey et al. 1988). Entretanto, reduções no pH parecem afetar a digestão da fibra parcialmente (Hoover, 1986). Outras fontes de carbono como amido, maltose e manose, afetariam a digestibilidade da fibra (Hoover, 1986; Haddad \& Grant, 2000), independente do efeito do $\mathrm{pH}$.

Em dietas exclusivas de forragem, a digestão da parede celular está associada ao teor de lignina ou até mesmo à quantidade de determinados constituintes da lignina como os ácidos p-cumárico e ferúlico (Jung \& Fahey, 
1984). Segundo Akin (1982) estes componentes da lignina deprimem o crescimento dos microrganismos "in vitro".

Hoover (1986), em extensa revisão de literatura, observou que a adição de carboidratos rapidamente fermentáveis, em dietas com forragem, reduziu a digestão da fibra em experimentos "in vivo" e "in vitro". Segundo esse autor, a quantidade de $10 \%$ a $15 \%$ de carboidratos rapidamente fermentáveis no rúmen seria suficiente para promover queda na digestão da fibra, embora severas depressões são comumente associadas à níveis de $30 \%$ de inclusão de grãos, ou outras formas de carboidratos rapidamente fermentáveis. Entretanto, alguns trabalhos não apresentaram efeito da inclusão de carboidratos não estruturais sobre a taxa e a degradabilidade efetiva da matéria seca de forragens tropicais (Berchielli et al. 1996) e sobre a fração potencialmente degradável da FDN de gramíneas temperadas ensiladas (De Visser et al. 1998).

Euclides et al. (1999) observaram valores de degradabilidade "in situ" da matéria seca do capim Tanzânia (Panicum maximum), após 96 horas de incubação, de $70,2 \%$ no verão e $67,1 \%$ no inverno $(P<0,05)$,sem o uso de suplementos para os animais.

Segundo Dixon \& Stockdale (1999) a utilização de suplementos contendo carboidratos não estruturais exerce efeito negativo mais acentuado sobre forragens de menor valor nutritivo. Leventine et al. (1990) observou que a degradabilidade potencial e a taxa de degradabilidade da MS foram maiores para forragens de melhor qualidade, quando comparada às de menor qualidade, quando foram incluídos níveis crescentes de concentrados na dieta. Esses autores também observaram efeito linear do nivel de concentrado sobre a degradabilidade potencial da MS e da FDN após 96 horas de incubação.

Além da qualidade da forragem, a origem do suplemento pode ter impacto diferente sobre a degradação da MS e da FDN. Nussio (1997) observou reduções na degradação da MS e FDN, bem como redução nas taxas de degradação destas frações do feno de alfafa, quando o sorgo laminado foi substituido por sorgo floculado em dietas para vacas leiteiras. Resultados 
semelhantes foram observados por Weiss (1994) e Harmisson et al. (1997). Entretanto, Lima (2000) não observou efeito do processamento do grão (floculação contra moagem fina), sobre a degradabilidade efetiva e a taxa de degradação da MS e da FDN do capim elefante fornecido para vacas em lactação. A degradabilidade efetiva da MS e da FDN do capim elefante foram de $63 \%$ e $62,7 \%$ respectivamente.

Krysl et al.(1989) não observaram efeito do uso de suplemento energético (0,5 kg cab ${ }^{-1} \mathrm{dia}^{-1}$ de sorgo floculado) e nem do uso de suplemento protéico $\left(0,5 \mathrm{~kg} \mathrm{cab}^{-1} \mathrm{dia}^{-1}\right.$ de farelo de soja) sobre a degradação da FDN nos diferentes tempos de incubação $(P>0,10)$, sobre a degradabilidade potencial em 72 horas de incubação $(P>0,10)$ e sobre a taxa de degradação $(P>0,10)$ da FDN de forragem nativa de bom valor nutritivo (PB > 11\%), incubada no rúmen de novilhos em pastejo. Os valores de degradabilidade potencial obtidos foram de 53,6; 54,6 e 55,3\%; e as taxas de degradação foram de 3,3; 3,0 e $3,0 \% \mathrm{~h}^{-1}$ para os tratamentos controle (sem suplemento), suplemento energético e suplemento protéico, respectivamente.

Hess et al. (1996) estudaram o efeito do uso de fontes de fibra ou de amido sobre a degradabilidade potencial e a taxa de degradação da FDN do capim festuca contendo elevado valor nutritivo (\% PB $\geq 12 \%$ ). Constataram redução $(P=0,01)$ na taxa de degradação de $7,5 \% \mathrm{~h}^{-1}$ para 5,4 a $5,7 \% \mathrm{~h}^{-1}$ com a suplementação dos animais em pastejo, independente da fonte de carboidrato utilizado no suplemento. Entretanto, não houve efeito do tipo de suplemento (0,34\% do PV em milho moído contra $0,34 \%$ do PV em farelo de trigo) e da quantidade de suplemento utilizada $(0,34 \%$ vs $0,48 \%$ do PV de farelo de trigo), sobre a taxa de degradação. A degradabilidade potencial obtida as 96 horas de incubação não apresentou diferença significativa $(P>0,10)$ entre os animais recebendo a dieta controle e os animais suplementados. Com isso, ressalta-se que o uso de suplemento reduziu $(P=0,02)$ a degradação da FDN nos tempos de 6,9 e 24 horas $(P<0,05)$ de incubação. Segundo os autores a lenta degradação, na fase inicial da incubação, levou à menor taxa de degradação da 
FDN $\left(\% \mathrm{~h}^{-1}\right)$. Mertens \& Loften (1980) estudaram o efeito do amido de milho e de trigo na digestão "in vitro" da fibra e sugeriram que o amido altera a digestão da fração fibrosa dos alimentos, principalmente por aumentar o "lag time".

A substituição da casca de soja por grão de milho em suplementos fornecidos na base de $40 \%$ da MS da dieta, não provocou redução na taxa (\% $\mathrm{h}^{-1}$ ) e nem na extensão da degradação da MS (96 horas) em feno de baixo valor nutritivo. Entretanto, quantidades crescentes de milho no suplemento oferecido, apresentaram efeito linear negativo sobre a degradabilidade da MS da forragem às 4 e 8 horas $(P<0,02)$ e às 12 horas $(P=0,07)$ de incubação (Grigsby et al. 1993).

Bodine et al. (2001) comparou o uso de suplemento protéico e dois tipos de fontes de energia (grãos contra uma mistura de farelo de trigo + casca de soja) para suplementar forragem de baixa qualidade (5,5\% de PB). Os autores não observaram efeito da suplementação e nem da origem de suplemento utilizado, sobre a degradabilidade potencial, após 72 horas de incubação da MS da forragem, apresentando valores de $63,83 \%$ para grãos e $68,05 \%$ para os não suplementados $(P>0,10)$. Entretanto, a suplementação elevou a taxa de degradação da MS da forragem de $1,92 \%$ para $2,88 \%$ a $3,35 \%$. O efeito positivo da suplementação nesse experimento ocorreu provavelmente, devido os suplementos elevarem o nível de proteína da dieta, já que o feno apresentava restrições qualitativas e os suplementos foram formulados para fornecer $1,1 \mathrm{~g}$ de PDR $\mathrm{kg}$ de $\mathrm{PV}^{-1}$. Lodman et al. (1990) também observaram efeito positivo da suplementação protéica sobre a taxa de degradação da MS e da FDN.

Pordomingo et al (1991) avaliaram niveis de suplementação, com milho laminado, sobre a degradação da matéria orgânica de forragem de elevado valor nutritivo consumida por novilhos em pastejo. Os autores observaram que o nivel mais baixo de suplementação ( $0,2 \%$ do PV) aumentou a degradação potencial da matéria orgânica da forragem, após 96 horas de incubação, quando comparada ao controle, enquanto que, níveis mais elevados de 
suplementação (0,4 e $0,6 \%$ do PV) deprimiram a degradação potencial da matéira orgânica. A taxa de degradação da matéria orgânica, observada para forragem incubada no rúmen de novilhos que receberam $0,2 \%$ do $\mathrm{PV}$ de milho, apresentou apenas tendência de se elevar, quando comparada aos demais tratamentos. Há evidências de que efeitos associativos positivos podem ocorrer quando baixos níveis de carboidratos rapidamente fermentáveis no rúmen são adicionados em dietas com forragens de baixa a média qualidade, devido ao estímulo da digestão microbiana da forragem e síntese de proteína microbiana (Opatpatanakit et al. 1995).

Chase Junior \& Hibberd (1987) observaram redução linear na taxa de degradação da MS e da FDN do feno, com 4,2\% de PB, ao fornecerem 0, 1, 2 e $3 \mathrm{~kg}$ de milho moído por dia. Heldt et al. (1998) observaram redução na taxa de degradação $(P<0,01)$ e na degradabilidade potencial da MS, após 72 horas de incubação $(P=0,06)$ de feno de gramínea de baixo valor nutritivo, quando elevaram a quantidade de farelo de trigo na dieta dos animais. A mesma situação foi observada quando os autores avaliaram a degradabilidade da FDN do feno.

O objetivo desse ensaio foi avaliar o efeito da origem do suplemento energético e da suplementação protéica sobre a degradabilidade ruminal do capim Tanzânia manejado sob dois resíduos de matéria seca verde pós pastejo.

\subsection{Material e métodos}

\subsubsection{Instalações experimentais e animais}

O experimento foi realizado na fazenda Areão da ESALQ/USP em uma área de 6 hectares estabelecida com capim Tanzânia (Panicum maximum Jacq. Cv. Tanzania) sob irrigação com equipamento do tipo pivô central, subdividida em quatro blocos. Cada bloco foi composto por um conjunto de seis piquetes, 
com três piquetes para cada resíduo de pastejo, perfazendo um total de 24 subdivisões, com $1500 \mathrm{~m}^{2}$ cada, divididas por cercas fixas e/ou eletrificadas. Cada resíduo de pastejo testado foi dividido em 12 piquetes. O manejo adotado para o sistema constitui-se em um intervalo de descanso de 33 dias, com três dias de ocupação para cada piquete. A forragem recebeu fertilização na dose de $334 \mathrm{~kg} \mathrm{ha}^{-1}$ da fórmula 24-04-24 (80 kg de $\mathrm{N} \mathrm{ha}^{-1}$ ) para cada ciclo de pastejo, logo após a saída dos animais.

Foram utilizados oito garrotes da raça Nelore, com peso vivo médio de $306,6 \mathrm{~kg}$, divididos em dois grupos de quatro animais cada, em um delineamento experimental contendo dois quadrados latinos $4 \times 4$, um para cada resíduo de pastejo estudado. Em cada quadrado latino foram testados quatro formas de suplementação. Os animais utilizados neste experimento sofreram adaptação prévia às instalações e à cirurgia de implantação das cânulas no rúmen e no duodeno proximal.

\subsubsection{Tratamentos}

Um grupo de quatro animais permaneceu durante o período experimental em doze piquetes rotacionados, manejados para atingirem resíduo pós pastejo de $1000 \mathrm{~kg}$ de matéria seca verde ha-1 (R1), enquanto o outro grupo de quatro animais permaneceu em doze piquetes rotacionados, manejados com o objetivo de atingir $4000 \mathrm{~kg}$ de matéria seca verde ha-1 (R2), de resíduo pós pastejo (Penati, 2002). Os quatro animais utilizados em cada tratamento de resíduo pós pastejo, foram mantidos juntamente com outros animais chamados de traçadores, que entravam e saíam dos piquetes, com o objetivo de obter-se os resíduos pós pastejo desejados. A cada intervalo de 33 dias os animais retornavam ao piquete inicial do sistema.

Em cada resíduo pós pastejo haviam quatro tratamentos de suplementação: 
S0 - Controle, sem suplementação (SS)

$\mathrm{S} 1$ - 2,24 $\mathrm{kg} \mathrm{dia}^{-1}$ de milho moído grosso em peneira de $8 \mathrm{~mm}$ (MMG)

$\mathrm{S} 2$ - 2,24 $\mathrm{kg} \mathrm{dia}^{-1}$ de milho floculado (360 g.L $\mathrm{L}^{-1}$ ) (MF)

$\mathrm{S} 3-0,8 \mathrm{~kg} \mathrm{dia}^{-1}$ de farelo de soja (FS)

O milho floculado preparado pela Cia Sul Mineira, Varginha-MG, se submeteu aos ajustes de equipamento visando intensidade de processamento físico necessário para obter-se densidade final de $360 \mathrm{~g} \mathrm{~L}^{-1}$.

As quantidades de suplementos energéticos ofertadas foram compativeis com a expectativa de disponibilidade da fração nitrogenada proveniente da pastagem, para garantir um desempenho estimado de ganho ao redor de $1,2 \mathrm{~kg}$ $\mathrm{dia}^{-1}$ e $1,3 \mathrm{~kg} \mathrm{dia}^{-1}$ respectivamente, para os tratamentos S1 e S2 (NRC, 1996). No caso do tratamento $\mathrm{S} 4$, a oferta adicional de farelo de soja, simulou a possibilidade de amplificação da síntese de proteína microbiana, com a elevação da disponibilidade de uma fonte de proteina de maior taxa de degradação ruminal, atingindo níveis mais elevados de proteína dietética e amônia ruminal.

Os suplementos foram fornecidos duas vezes ao dia em quantidades iguais ( $50 \%$ do total pela manhã e $50 \%$ à tarde), em torno das 7 e 16 horas, através da cânula ruminal para garantir que toda a quantidade de suplemento fosse ingerida. Os animais tinham livre acesso a misturas minerais colocadas em cochos próprios disponiveis em cada piquete de pastejo.

\subsubsection{Período experimental}

Um período pré-experimental de 5 meses, foi necessário para amansar os animais e realizar as cirurgias, e a completa recuperação dos animais no periodo pós cirúrgico.

O período experimental teve duração de 50 dias, iniciando no dia 
05/12/1999 e encerrando dia 24/01/2000. Este período foi subdividido em 4 subperíodos, de 12 a 13 dias de extensão, com 8 a 9 dias de adaptação e 4 dias de coleta de conteúdo ruminal. A variação no período de adaptação ocorreu em função das condições metereológicas que permitissem o manejo dos animais.

\subsubsection{Degradabilidade "in situ"}

O ensaio de degradabilidade "in situ" da MS, FDN e FDA, foi realizado com forragem colhida no estrato acima de $7 \mathrm{~cm}$ do solo para o R1 e $37 \mathrm{~cm}$ do solo para R2, objetivando simular a forragem disponivel para pastejo pelos animais, submetidos a cada um dos resíduos avaliados.

As amostras foram secas em estufa com circulação de ar a $60^{\circ} \mathrm{C}$ por 72 horas, e moídas em moinhos tipo Willey com peneira de $5 \mathrm{~mm}$. Sub-amostras deste material, pesando aproximadamente 6 gramas, foram colocados em sacos de nailon $10 \times 20 \mathrm{~cm}$, com porosidade de $45 \mu \mathrm{m}$, previamente pesados. Os sacos foram agrupados em uma argola com ganchos de metal, e esta argola foi presa a uma corda de nailon de $50 \mathrm{~cm}$, de modo a evitar que os saquinhos ultrapassassem o limite do compartimento ruminal. Os sacos foram posicionados submersos no rúmen de todos os garrotes de cada resíduo. Os horários utilizados para avaliar a degradabilidade foram: 0, 24, 48, 72 e 96 horas. Para cada horário haviam dois sacos de nailon. Os saquinhos foram colocados em ordem reversa, sempre às 7:30 horas, e retirados simultaneamente, visando reduzir os possíveis erros no momento da lavagem.

Retirados do rúmen, os saquinhos foram lavados imediatamente em água corrente até que esta se apresentasse limpa. Os sacos referentes ao tempo 0 foram lavados juntamente com os demais. Os saquinhos foram levados para secagem em estufa de ventilação forçada a $60^{\circ} \mathrm{C}$ por 72 horas, e peso foi registrado para determinação da MS do resíduo. As amostras do resíduo foram moídas em moinho Willey com peneira de $1 \mathrm{~mm}$ e foram analisadas para determinação da FDN e FDA pelo método sequencial descrito por Van Soest et 
al. (1991), utilizando-se o equipamento Fiber Analyser Ankom 200 (Holden, 1999).

Os dados das amostras incubadas foram processados utilizando o programa "fit curve" desenvolvido pela Rowett Research Institute, Aberdeen, Escócia. O programa oferece os parâmetros do modelo de degradabilidade ruminal segundo Orskov \& McDonald (1979), entre outras informações. As degradabilidades potenciais "in situ" da matéria seca, FDN e FDA foram calculadas de acordo com a equação:

$D g=a+b\left(1-e^{-c t}\right)$

Sendo:

Dg = degradabilidade estimada, \%;

$a=$ interseção da curva no tempo 0 , podendo ser interpretada como fração rapidamente solúvel, \%;

b = fração insolúvel em água, mas potencialmente degradável, \%;

$c=$ taxa de degradação da fração b por hora $\% \mathrm{~h}^{-1}$;

e = logaritimo natural;

$\mathrm{t}=$ tempo de incubação, $\mathrm{h}$;

$a+b=$ potencial de degradabilidade, $\%$;

A degradabilidade efetiva foi calculada pela equação de Orskov \& McDonald (1979):

$D E=a+\left(b \times c^{-c+k p}\right)$

Onde:

$\mathrm{kp}=\mathrm{a}$ taxa de passagem, $\% \mathrm{~h}^{-1}$;

Para cálculo o da degradabilidade efetiva, foi considerarada a taxa de 
passagem dos alimentos pelo rúmen. Recomenda-se o valor de $2 \% \mathrm{~h}^{-1}$ para animais recebendo ração completamente moída e/ou sob menor consumo (mantença), $5 \% \mathrm{~h}^{-1}$ para vacas leiteiras de baixa produção (menos de $15 \mathrm{~kg}$ de leite.dia ${ }^{-1}$ ) ou gado de corte recebendo alto nível de dietas mistas (menos que 2 vezes a mantença) e $8 \% \mathrm{~h}^{-1}$ para vacas leiteiras de alta produção (mais de 15 $\mathrm{kg}$ de leite $\mathrm{dia}^{-1}$ ) recebendo dietas mistas (mais que 2 vezes a mantença) (AFRC, 1992).

Adotou-se o valor de $\mathrm{kp}=2 \% \mathrm{~h}^{-1}$ como valor padrão para a estimativa de degradabilidade efetiva, uma vez que em ambos resíduos houveram ganhos de peso para os animais testadores, para avaliação do sistema de pastejo rotacionado irrigado em capim Tanzânia, que acompanharam os animais canulados utilizados para coleta de dados neste experimento.

\subsubsection{Análise estatística}

O experimento foi conduzido em um delineamento tipo quadrado latino 4 $x 4$, com um quadrado para cada resíduo pós pastejo. Em cada quadrado latino (resíduo pós pastejo) foram estudados quatro suplementos (S0, S1, S2 e S3). Foi adotado o nível de significância de 5\% para declarar a diferença estatística na análise de variância Utilizou-se contrastes não ortogonais para comparação entre as médias dos suplementos utilizados, com nível de significância de 5\%. Os contrastes utilizados foram:
a) $\mathrm{SO}$ vs $\mathrm{S} 1+\mathrm{S} 2+\mathrm{S} 3$
b) $\mathrm{S3}$ vs $\mathrm{S} 1+\mathrm{S} 2$
c) $\mathrm{S} 1 \mathrm{vs} \mathrm{S} 2$
d) $\mathrm{SO}$ vs $\mathrm{S} 1+\mathrm{S} 2$
e) $\mathrm{SO}$ vs $\mathrm{S3}$

Para análise da variância e comparação das médias foi utilizado o 
procedimento GLM do programa SAS (1991). As médias foram obtidas através dos quadrados mínimos, utilizando o comando LSMEANS do programa SAS (1991). O quadro da análise de variância proposto para os dados é apresentado na tabela 1. Como não houve interação entre resíduo pós pastejo e a suplementação sobre os parâmetros de degradabilidade "in situ" a interação foi retirada do modelo.

Foram analisados os seguintes parâmetros de degradabilidade "in situ" da MS, FDN e FDA: a (fração solúvel), b (fração potencialmente degradável e não solúvel), c (taxa de degradação), $a+b$ (fração potencialmente degradável) e estimativas de degradabilidade efetiva para taxa de passagem de $2 \%$.

Tabela 1. Esquema de análise da variância para o ensaio de degradabilidade ruminal.

\begin{tabular}{lc}
\hline Causas de variação & Graus de liberdade \\
\hline Quadrado Latino & 1 \\
Animais (QL) & 6 \\
Suplementos & 3 \\
Período & 3 \\
Resíduo & 18 \\
Total & 31 \\
\hline
\end{tabular}

\subsection{Resultados e discussão}

Os parâmetros de degradabilidade "in situ" da MS, da FDN e da FDA, encontram-se nas tabelas 2, 3 e 4 , respectivamente. Não ocorreu efeito significativo $(P>0,05)$ da suplementação com concentrados, sobre os parâmetros das frações de degradação estudadas. Provavelmente, a ausência de efeito da suplementação sobre os parâmetros de degradabilidade explica-se, pelo fato de que a forragem pastejada apresentou bom valor nutritivo, uma vez que segundo Dixon \& Stockdale (1999), as forragens de melhor qualificação 
sofrem efeitos menos acentuados nos parâmetros de degradação, quando suplementadas com carboidratos não estruturais.

A suplementação com $0,2 \%$ do peso vivo com milho laminado aumentou a taxa de degradação potencial da matéria orgânica de forragens de bom valor nutritivo às 96 horas de incubação, em relação ao controle; enquanto niveis mais elevados de milho laminado $(0,4$ e $0,6 \%$ do PV) deprimiram esse parâmetro em relação à dieta controle (Pordomingo et al. 1991). Esses autores não observaram efeito da presença e nem dos níveis de inclusão do milho laminado sobre a taxa fracional de degradação da matéria orgânica da forragem.

Berchielli et al. (1996) não observou efeito de níveis crescentes de concentrado sobre o potencial de degradação, sobre a fração potencialmente degradável, sobre a taxa fracional de degradação e sobre a degradabilidade efetiva da matéria seca do feno de coast-cross (Cynodon dactylon).

Bodine et al. (2001) não observaram efeito significativo da suplementação sobre a degradabilidade potencial da MS da forragem as 72 horas com feno de gramínea de baixo valor nutritivo, embora a utilização de suplementos tenha elevado a taxa de degradação fracional da matéria seca da forragem de menor valor nutricional, devido ao aumento na ingestão de PB pelos animais suplementados. 
Tabela 2. Médias dos quadrados mínimos dos parâmetros de degradabilidade "in situ" da matéria seca do capim Tanzânia (Panicum maximum Jacq.) proveniente de dois resíduos pós pastejo (RPP), R1 e R2, incubados no rúmen de garrotes suplementados com fontes de energia ou de proteína.

\begin{tabular}{|c|c|c|c|c|c|}
\hline \multirow[t]{2}{*}{ Parâmetros } & \multirow{2}{*}{$\mathrm{R} 1^{\mathrm{b}}$} & \multirow[t]{2}{*}{$\mathrm{R} 2$} & \multirow{2}{*}{$\mathrm{EPM}^{\mathrm{a}}$} & \multicolumn{2}{|c|}{ Efeitos Principais } \\
\hline & & & & RPP & SUP $^{\bar{c}}$ \\
\hline a (\%) & 15,85 & 17,72 & 0,6445 & 0,0582 & 0,7319 \\
\hline b (\%) & 66,90 & 64,81 & 2,4066 & 0,5500 & 0,6020 \\
\hline$c^{e}\left(\% h^{-1}\right)$ & 2,47 & 3,05 & 0,0040 & 0,3286 & 0,6075 \\
\hline Pot. Degradável $^{d}(\%)$ & 82,77 & 81,92 & 2,1461 & 0,7833 & 0,4882 \\
\hline Ef. Degradável ${ }^{f}(\%)$ & 45,71 & 44,41 & 2,3120 & 0,6954 & 0,5711 \\
\hline
\end{tabular}

${ }^{a}$ EPM = erro padrão da média.

${ }^{\mathrm{b}} \mathrm{R} 1=1000 \mathrm{~kg} \mathrm{~h}^{-1}$ de matéria seca verde, $\mathrm{R} 2=4000 \mathrm{~kg} \mathrm{~h}^{-1}$ de matéria seca verde.

${ }^{\mathrm{c}}$ SUP = efeito da suplementação com fonte de energia ou proteína.

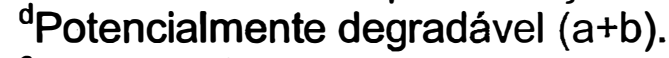

${ }^{\mathrm{e}} \mathrm{kd}=$ taxa fracional de de degradação $\left(\% \mathrm{~h}^{-1}\right)$.

'Efetivamente degradával $(\mathrm{kp}=2 \%)$.

A inclusão de níveis crescentes de milho na dieta de bovinos, recebendo feno de baixo valor nutritivo, reduziu linearmente a taxa de degradação fracional da MS e da FDN (Chase Jr \& Hibberd, 1987). Heldt et al. (1998) observaram redução na taxa fracional de degradação da MS e da degradabilidade potencial da MS e da FDN as 72 horas com a elevação da quantidade de farelo de trigo utilizada como suplemento para forragem de baixo valor nutricional.

A origem do suplemento foi avaliada por Hess et al. (1996), que observaram efeito da suplementação com fontes de fibra ou amido, sobre a taxa fracional de degradação da parede celular de forragem de bom valor nutritivo. Esses autores mencionaram redução na taxa fracional de degradação 
da FDN da forragem de boa qualificação, de $7,5 \% \mathrm{~h}^{-1}$, para 5,4 a $5,7 \% \mathrm{~h}^{-1}$. Entretanto esses autores não detectaram efeito da suplementação sobre a degradabilidade potencial da FDN às 96 horas, e nem encontraram diferenças entre a origem do suplemento (fibra ou amido) sobre esses parâmetros. A ausência de efeito da inclusão de concentrados sobre a degradabilidade potencial da FDN de gramíneas ensiladas foi relatada por De Visser et al. (1988).

A suplementação não exerceu efeito sobre os parâmetros de degradabilidade "in situ" da FDN e FDA. Os valores médios de $\mathrm{pH}$ ruminal registrados neste experimento (Tabela 12 capítulo 3 ), embora tenham sofrido redução decorrente da suplementação, esta não foi suficientemente acentuada resultando em valores médios sempre acima de 6,2. Segundo Fahey et al. (1988) a taxa fracional de degradabilidade e a extensão da degradabilidade da fibra são comprometidas quando a queda do $\mathrm{pH}$ for pronunciada. Além disso a concentração de nitrogênio amoniacal apresentou-se acima do valor considerado limitante a digestão da fibra (Tabela 12 capítulo 3 ).

$O$ resíduo pós pastejo também não demonstrou significância $(P>0,05)$ sobre os parâmetros de degradabilidade "in situ" da matéria seca (Tabela 2). A explicação mais provável para este fato é que, embora no R1 as disponibilidades de matéria seca verde e de matéria seca de folhas fossem inferiores quando comparadas às do R2 (Tabela 3 capítulo 4), o valor nutritivo da forragem colhida através da simulação de pastejo foi muito próximo (Tabela 1 capítulo 3 ). Se a forragem colhida através de pastejo simulado, dos dois resíduos pós pastejo apresentasse valores nutritivos diferentes, provavelmente haveria diferenças entre os parâmetros de degradabilidade "in situ" da matéria seca. Leventini et al. (1990) observaram efeito do valor nutritivo entre plantas forrageiras, que foram colhidas em duas idades de crescimento distintas, sobre a taxa de degradação fracional e sobre a degradabilidade potencial da MS as 96 horas, que apresentaram-se inferiores na forragem de menor valor nutritivo. No presente experimento, o período de descanso utilizado no manejo da 
pastagem foi semelhante entre os dois resíduos pós pastejo estudados, sendo insuficiente para causar diferença mais acentuada sobre o valor nutritivo da forragem, conforme os valores de NDT observados na tabela 13 do capítulo 1.

A degradabilidade potencial da MS, às 96 horas, registrada no presente experimento esteve acima dos valores observados por Euclides et al. (1999) para o capim Tanzânia, incubado no rúmen de animais em pastejo, sem receber suplementação, que foram de $70,2 \%$ para forragem colhida no verão e de $67,1 \%$ para aquela colhida no inverno. Lima (2000) registrou valores de degradabilidade potencial da MS do capim elefante, suplementado com grãos, próximos de $70 \%$.

As taxas fracionais de degradação da MS da forragem colhida em R1 e R2 não diferiram entre si, e encontram-se próximas dos valores obtidos por Berchielli et al. (1996) e abaixo dos valores encontrados por Lima (2000).

Os valores de degradabilidade efetiva da matéria seca da forragem observados no presente experimento apresentaram-se muito abaixo dos registrados com capim elefante por Balsalobre (1996) e Lima (2000), que encontraram valores médios de $67,9 \%$ e $63 \%$, respectivamente, adotando o valor para taxa de passagem ( $\mathrm{kp}$ ) de 5\%. Entretanto, Berchielli et al. (1996) observaram valores para degradabilidade efetiva da matéria seca do feno de coast-cross (Cynodon dactylon) variando entre 31,21 a 36,25\%, utilizando um kp igual a $5 \%$. 
Tabela 3. Médias dos quadrados mínimos dos parâmetros de degradabilidade "in situ" da FDN do capim Tanzânia (Panicum maximum Jacq.) proveniente de dois resíduos pós pastejo (RPP) R1 e R2, incubados no rúmen de garrotes suplementados com fontes de energia ou de proteína.

\begin{tabular}{|c|c|c|c|c|c|}
\hline \multirow[t]{2}{*}{ Parâmetros } & \multirow[t]{2}{*}{$\mathrm{R} 1^{\mathrm{b}}$} & \multirow[t]{2}{*}{$\mathrm{R} 2$} & \multirow[t]{2}{*}{$\mathrm{EPM}^{\mathrm{a}}$} & \multicolumn{2}{|c|}{ Efeitos Principais } \\
\hline & & & & RPP & SUP $^{\bar{c}}$ \\
\hline$a(\%)$ & 4,61 & 7,99 & 1,4152 & 0,1124 & 0,9905 \\
\hline $\mathrm{b}(\%)$ & 76,42 & 69,28 & 2,0182 & 0,0246 & 0,5882 \\
\hline$c^{e}\left(\% h^{-1}\right)$ & 2,85 & 4,17 & 0,0032 & 0,0116 & 0,9759 \\
\hline Pot. Degradável $^{d}(\%)$ & 81,03 & 77,27 & 1,8255 & 0,1663 & 0,6318 \\
\hline Ef. Degradável ${ }^{\dagger}(\%)$ & 40,50 & 46,16 & 2,1783 & 0,0859 & 0,4440 \\
\hline $\begin{array}{l}{ }^{\mathrm{a}} \mathrm{EPM}=\text { erro padrão d } \\
{ }^{\mathrm{b}} \mathrm{R} 1=1000 \mathrm{~kg} \mathrm{~h}^{-1} \mathrm{de} \\
\text { verde. } \\
{ }^{\mathrm{c}} \text { SUP = efeito da supl } \\
{ }^{\mathrm{d}} \text { Potencialmente degr } \\
{ }^{\mathrm{e}} \mathrm{kd}=\text { taxa fracional de } \\
{ }^{\mathrm{f}} \mathrm{Efetivamente} \text { degrad }\end{array}$ & $\begin{array}{l}\text { tação } \\
\text { el (a+1 } \\
\text { legra } \\
\mathrm{kp}=2\end{array}$ & $\begin{array}{l}\text { fonte de } \\
\left(\% h^{-1}\right) \text {. }\end{array}$ & ergia c & $\begin{array}{l}\mathrm{h}^{-1} \text { de } \mathrm{m} \\
\text { oteína. }\end{array}$ & seca \\
\hline
\end{tabular}

A fração insolúvel mas potencialmente degradável do FDN da forragem colhida no R1 foi superior $(P<0,05)$, fato que explica a tendência $(P=0,11)$ do menor valor de fração solúvel (a), uma vez que a fração potencialmente degradável foi similar em R1 e R2 conforme pode ser observado na tabela 3. A taxa de degradação fracional do FDN foi inferior em $R 1(P<0,05)$ em relação ao R2, justificando a tendência de menor degradabilidade efetiva em R1 ( $P=$ 0,086). Leventini et al. (1990) encontraram taxa de degradação fracional (c) e degradabilidade potencial da FDN menor para forragem de menor valor nutritivo, às 96 horas de incubação.

A fração (b), insolúvel mas potencialmente degradável, foi superior aos 
valores observados por Lima (2000) para capim elefante que registrou 59,34 a $62,36 \%$, e Rosa et al. (1996) para Brachiaria decumbens que observaram uma fração "b" igual a 58,7\%. A taxa fracional de degradação da forragem colhida no R2 foi superior e do R1 foi similar quando comparadas à amplitude de valores obtidos por Lima (2000) com capim elefante, 3,46 a 4,3\% $\mathrm{h}^{-1}$. O potencial de degradação da FDN às 96 horas do capim Tanzânia colhido nos dois resíduos pós pastejo foi maior que os observados por Lima (2000) e Rosa et al. (1996). Lima (2000) registrou médias para o potencial de degradação da FDN do capim elefante às 96 horas de incubação, de 66,1 a 69,1\% e Rosa et al. (1996) obtiveram valores para o potencial de degradação da FDN da Brachiaria decumbens, de $70,6 \%$. Valores mais próximos aos obtidos nesse experimento, para degradabilidade potencial da FDN, foram reportadas por Hess et al. (1996) se situando na amplitude compreendida entre 71 e $74,8 \%$, após 96 horas de incubação, da extrusa coletada de animais pastejando gramíneas de elevado valor nutritivo.

A degradabilidade efetiva apresentou-se inferior aos valores observados por Lima (2000), que obteve $62,7 \%$ com uma taxa de passagem de $5 \% \mathrm{~h}^{-1}$ e superior ao relatado por Vieira et al. (1996), que observaram valores de 28,74 a $34,23 \%$ para capim elefante com 61 e 82 dias de crescimento. Entretanto, os valores aproximam-se das observações mencionadas por Rosa et al. (1996), que foi $45,9 \%$, para $B$. decumbens utilizando uma taxa de passagem de $2,4 \% \mathrm{~h}^{-1}$. 
Tabela 4. Médias dos quadrados mínimos dos parâmetros de degradabilidade "in situ" da FDA do capim Tanzânia (Panicum maximum Jacq.) provenientes de dois resíduos pós pastejo (RPP) R1 e R2, incubados no rúmen de garrotes suplementados com fontes de energia ou de proteína.

\begin{tabular}{|c|c|c|c|c|c|}
\hline \multirow{2}{*}{ Parâmetros } & \multirow{2}{*}{$\mathrm{R} 1^{\mathrm{b}}$} & \multirow[t]{2}{*}{$\mathrm{R} 2$} & \multirow{2}{*}{$\mathrm{EPM}^{\mathrm{a}}$} & \multicolumn{2}{|c|}{ Efeitos Principais } \\
\hline & & & & RPP & SUP' \\
\hline$a(\%)$ & 6,67 & 8,50 & 1,7173 & 0,4640 & 0,9937 \\
\hline$b(\%)$ & 77,76 & 67,59 & 2,2123 & 0,0054 & 0,8268 \\
\hline$c^{e}\left(\% h^{-1}\right)$ & 4,23 & 4,00 & 0,0105 & 0,8774 & 0,4370 \\
\hline Pot. Degradável ${ }^{d}(\%)$ & 84,43 & 76,09 & 1,6991 & 0,0034 & 0,6143 \\
\hline Ef. Degradável ${ }^{f}(\%)$ & 41,99 & 45,85 & 2,5636 & 0,3036 & 0,7205 \\
\hline
\end{tabular}

${ }^{\mathrm{a} E P M}=$ erro padrão da média.

${ }^{\mathrm{b}} \mathrm{R} 1=1000 \mathrm{~kg} \mathrm{~h}^{-1}$ de matéria seca verde, $\mathrm{R} 2=4000 \mathrm{~kg} \mathrm{~h}^{-1}$ de matéria seca verde.

'SUP = efeito da suplementação com fonte de energia ou proteína.

${ }^{d}$ Potencialmente degradável $(a+b)$.

${ }^{e} k d=$ taxa fracional de de degradação $\left(\% h^{-1}\right)$.

'Efetivamente degradával $(\mathrm{kp}=2 \%)$.

A fração (b), insolúvel mas potencialmente degradável e a consequente resposta na degradabilidade potencial $(a+b)$ da fração FDA da forragem, foram superiores no $R 1$ em relação ao $R 2(P<0,05)$. Não foram observadas diferenças os demais parâmetros de degradabilidade "in situ" da fração (Tabela 4). Os resultados dos parâmetros de degradabilidade da FDA demonstram perfil semelhante aos parâmetros de degradabilidade da FDN, evidenciando a similaridade entre as frações FDN e FDA da forragem colhida nos dois resíduos pós pastejo.

Todos os valores registrados para os parâmetros de degradabilidade da FDA foram inferiores ao observados por Lima (2000), com capim elefante sob 
pastejo simulado e ofertado para vacas leiteiras recebendo concentrados. Essa autora registrou amplitudes variando entre 63,3 a 66,8\%, para a fração insolúvel mas potencialmente degradável, 3,07 a 3,83\%, para a taxa de degradação fracinal e $62,7 \%$ para degradabilidade efetiva, adotado $5 \%$ como taxa de passagem para a FDA do capim elefante. Apenas a degradabilidade potencial da forragem $(a+b)$ observada por Lima (2000) foi inferior à encontrada nesse experimento. Lima (2000) obteve degradabilidade potencial da FDA do capim elefante variando entre 67,3 e $70,2 \%$.

Não foram observadas alterações para a degradabilidade da MS da forragem, entre os resíduos R1 e R2, apesar de ter sido significativa o maior potencial de degradação dos compostos da parede celular da forragem colhida no R2. Esse fato associado à maior presença de folhas na forragem colhida em R1 (Tabela 3 capítulo 4), indica que o potencial de degradação da parede celular da fração haste da planta, tenha sido superior ao da fração folha, uma vez que o teor médio de FDN não variou entre as amostras de forragem colhidas nos dois resíduos pós pastejo (Tabela 1 capítulo 3 ).

\subsection{Conclusões}

Os resíduos pós pastejo $\mathrm{R} 1$ e $\mathrm{R} 2$, impostos ao manejo da pastagem, resultaram em elevado valor nutritivo de ambos, e quando suplementados apresentaram efeito pouco pronunciado nos parâmetros de degradabilidade ruminal da MS e da fração fibra.

O menor resíduo pós pastejo determinou redução potencial de degradação dos componentes da parede celular. 


\section{CONCLUSÕES GERAIS}

A disponibilidade de matéria seca verde na pastagem, é o grande limitante ao consumo de forragem por animais em pastejo, sobrepondo-se à utilização de suplementos.

A utilização de suplementos energéticos para bovinos em pastejo apresenta efeito mais acentuado quando a estrutura da pastagem esteja limitanto o consumo de energia digestível pelos animais.

O comportamento ingestivo sofre maior influência da disponibilidade de matéria seca verde presente na pastagem, quando comparada à administração de suplementos. 


\section{REFERÊNCIAS BIBLIOGRÁFICAS}

ACKERMAN, C. J.; PAISLEY, S. I.; PURVIS II, H. T.; HORN, G. W.; BODINE, T. $\mathrm{N}$. Summer gains of heavy vs light weight steers grazing old world bluestem at three stocking rates. Journal of Animal Science, v. 76, suppl. 1, p. 192, 1998.

ADAMS, D. C. Effect of time of supplementation on performance, forage intake and grazing behavior of yearling beef steers grazing russian wild ryegrass in the fall. Journal of Animal Science, v. 61, p. 1037 - 1042, 1985.

AGRICULTURAL AND FOOD RESEARCH COUNCIL. Technical Commitee on Responses to Nutrients. Report No. 9. Nutritive requirements of ruminants animals: protein. Nutrition Abstracts Reviews, v. 62, p. 787 - 835, 1992.

AKIN, D. E. Forage cell wall degradation and p-coumaric, ferulic and synapic acids. Agronomy Journal, v. 74, p. 424, 1982.

ALLEN, M. S. Relationship between fermentation acid production in the rumen and the requirement for physically effective fiber. Journal of Dairy Science, v. 80, p. $1477-1462,1997$.

ALLEN, M. S.; MERTENS, D. R. Evaluating constraints on fiber digestion by rumen microbes. Journal of Nutrition, v. 118, p. $261-270,1988$. 
AMARAL, D. M.; VEENHUIZEN, J. J.; DRACKLEY, J. K.; COOLEY, M. H.; MCGILLIARD, A. D.; YOUNG, J. W. Metabolism of propionate, glucose and carbon dioxide as affected by exogenous glucose in dairy cows at energy equilibrium. Journal of Dairy Science, v. 73, p. 1244 - 1254, 1990.

ANDERSON, S. J.; KLOPFENSTEIN, T. J.; WILKERSON, V. A. Escape protein supplementation of yearling steers grazing smooth brome pastures. Journal of Animal Science, v. 66, p. 237-242, 1988.

AROEIRA, L. J. M.; LOPES, F. C. F.; VASQUEZ, H. M.; DAYRELL, M. S.; DERESZ, F.; MATOS, L. L. de; VITTORI, A.; VERNEQUE, R. S. Disponibilidade e consumo do capim elefante ( $P$. purpureum, Schum.) sob diferentes intervalos de pastejo, por vacas em lactação. In: REUNIÃO ANUAL DA SOCIEDADE BRASILEIRA DE ZOOTECNIA, 33., Fortaleza, 1996. Anais. Fortaleza: SBZ, 1996. p. 177-179.

Association of Official Agricultural Chemists. Official methods of analysis. 13. ed. A. O. A. C. Washington, 1980.

BALDWIN, R. L.; ALLISON, M. J. Rumen matabolism. Journal of Animal Science, v. 57, Suplemento 2, p. 461-477, 1983.

BALSALOBRE, M. A. A. Desempenho de vacas em lactação sob pastejo rotacionado de capim elefante (Pennisetum purpureum Schum.). Piracicaba, 1996. 139 p. Dissertação (Mestrado) - Escola Superior de Agricultura "Luiz de Queiroz", Universidade de São Paulo.

BALSALOBRE, M. A. A. Valor alimentar do capim Tanzânia irrigado. Piracicaba, 2002. Tese (Doutorado) - Escola Superior de Agricultura "Luiz de Queiroz". Universidade de São Paulo (no prelo). 
BARTON, R. K.; KRYSL, L. J.; JUDKINS M. B.; HOLCOMBE D. W.; BROESDER, J. T.; GUNTER, S. A.; BEAM, S. W. Time of daily supplementation for steers grazing dormant intermediate wheatgrass pasture. Journal of Animal Science, v.70, p. 547 - 558, 1992.

BERCHIELLI, T. T.; FIGUEIRA, D. G.; RODRIGUEZ, N. M. Efeito de niveis de concentrado sobre a degradabilidade "in situ" da matéria seca. In: REUNIÃO ANUAL DA SOCIEDADE BRASILEIRA DE ZOOTECNIA, 33., Fortaleza, 1996. Anais. Fortaleza: SBZ, 1996. p. $39-40$.

BERGMAN, E. N. Energy contributions of volatile fatty acids from the gastrointestinal tract in various species. Physiological Reviews, v. 70, p. $567-590,1990$.

BODINE, T. N.; PURVIS II, H. T.; COX, D. A. Blood, ruminal and fecal measures of steers fed different combinations of supplemental energy and degradable intake protein while grazing winter range: Animal Science Research Report, Oklahoma State University. 2000a htttp://www.ansi.okstate.edu/research/2000rr/0.8htm. (21 ago. 2001)

BODINE, T. N.; PURVIS II, H. T.; COX, D. A. Effects of supplemental energy and degradable intake protein on grazing behavior, forage intake, digestion and performance of steers grazing winter forage: Animal Science Research Report, Oklahoma State University. 2000b htttp://www.ansi.okstate.edu/research/2000rr/0.7htm. (21 ago. 2001)

BODINE, T. N.; PURVIS II, H. T.; LALMAN, D. L. Effects of supplement type on animal performance, forage intake, digestion, and ruminal measurements of growing beef cattle. Journal of Animal Science, v. 79, p. 1041 - 1051, 2001. 
BOMFIM, M. A. D.; REZENDE, C. A. P. de; PAIVA, P. C. A.; ANDRADE, I. F. de; MUNIZ, J. A.; BOMFIM, E. R. P.; ALMEIDA, O. C. Efeito do nível de concentrado no tempo de pastejo de novilhos holandês $x$ zebu suplementados a pasto na estação seca. In: REUNIÃO ANUAL DA SOCIEDADE BRASILEIRA DE ZOOTECNIA, 37., Viçosa, 2000. Anais. Viçosa: SBZ, 2000. p. 10.

BOIN, C.; TEDESCHI, L. O.; LANNA, D. P. D. Atendimento das exigências nutricionais de bovinos no pastejo rotacionado. In: SIMPÓSIO SOBRE MANEJO DA PASTAGEM, 14., Piracicaba, 1997. Fundamentos do pastejo rotacionado: anais. Piracicaba: FEALQ, 1997. p. 297 - 316.

BRAKE, A. C.; GOETSCH, A L.; FORSTER Jr., L. A.; LANDIS, K. M. Feed intake, digestion and digesta characteristics of cattle fed bermudagrass or orchardgrass alone or with ground barley or corn. Journal of Animal Science, v. 67, p.3425-3436, 1989.

BRANDYBERRY, S. D.; COCHRAN, R. C.; VANZANT, E. S.; DeL CURTO, T.; CORAH, L. R. Influence of supplementation method on forage use and grazing behavior by beef cattle grazing bluestem range. Journal of Animal Science, v. 69, p. $4128-4136,1991$.

BRANINE, M. E.; GALYEAN, M. L. Influence of grain and monensin supplementation on ruminal fermentation, intake, digesta kinetics and incidence and severity of frothy bloat in steers grazing winter wheat pasture. Journal of Animal Science, v. 68, p. 1139 - 1150, 1990. 
CARDOSO, E. G. Suplementação de bovinos de corte em pastejo (semi confinamento). In: SIMPÓSIO SOBRE MANEJO DA PASTAGEM, 9., Piracicaba, 1996. Confinamento de bovinos: anais. Piracicaba: FEALQ, 1996. p. 97-120.

CARVALHO, P. C. F.; RIBEIRO FILHO, H. M. N.; POLI, C. H. E. C.; MORAES, A. de; DELAGARDE, R. Importância da estrutura da pastagem na ingestão e seleção de dietas pelo animal em pastejo. In: MATTOS, W. R. S. de (Ed.). A produção animal na visão dos brasileiros. Piracicaba: FEALQ, 2001. p. $853-871$.

CATON, J. S.; DHUYVETTER, D. V. Influence of energy supplementation on grazing ruminants: requiriments and responses. Journal of Animal Science, v. 75, p. 533-542, 1997.

CHACON, E.; STOBBS, T. H. Influence of progressive defoliation of a grass sward on the eating behaviour of cattle. Australian Journal of Agricultural Research, v. 27, p. $709-727,1976$.

CHANEY, A. L.; MARBACH, E. P. Modified reagents for determination of urea and ammonia. Clinical Chemistry, v. 8, p. 130 - 137, 1962.

CHASE Jr., C. C.; HIBBERD, C. A. Utilization of low-quality native grass hay by beef cows fed increasing quantities of corn grain. Journal of Animal Science, v. 65, p. $557-566,1987$.

CHEN, K. H.; HUBER, J. T.; THEURER, C. B.; SWINGLE, R. S.; SIMAS, J. M.; CHAN, S. C.; WU, Z.; SULLIVAN, J. L. Effect of steam flaking of corn and sorghum grains on performance of lactating cows. Journal of Dairy Science, v. 77, p. 1038 - 1043, 1994. 
CHURCH, D. C. Función y produción de saliva. In: $\mathrm{CHURCH}$, D. C. (Ed.) EI rumiante: fisiologia digestiva y nutricion. Zaragoza: Editorial Acribia, 1993. cap. 7 , p. $127-135$.

COMBS, D. K. Pasture suplementation and forage intake. In: INTERNATIONAL SYMPOSIUM ON ANIMAL PRODUCTION UNDER GRAZING, Viçosa, 1997. Proceedings. Viçosa: UFV, 1997. p. 209-233.

CONRAD, H. R.; PRATT, A. D.; HIBBS, J. W. Regulation of feed intake in dairy cows. I. Change in importance of physiological factors with increasing digestibility. Journal of Dairy Science, v. 47, p. 54 - 62, 1964.

CORSI, M.; MARTHA Jr., G. B. Manutenção da fertilidade do solo em sistemas intensivos de pastejo rotacionado. In: SIMPÓSIO SOBRE MANEJO DA PASTAGEM, 14., Piracicaba, 1997. Fundamentos do pastejo rotacionado: anais. Piracicaba: FEALQ, 1997. p. 161-192.

COSGROVE, G. P. Grazing behaviour and forage intake. In: INTERNATIONAL SYMPOSIUM ON ANIMAL PRODUCTION UNDER GRAZING, Viçosa, 1997. Proceedings. Viçosa: UFV, 1997. p. $59-80$.

COUTINHO FILHO, J. L. V.; JUSTO, C. L.; PERES, R. M. Efeito da suplementação protéica/energética sobre o desenvolvimento ponderal de fêmeas pastejando Brachiaria decumbens durante o ano (seca e águas). In: REUNIÃO ANUAL DA SOCIEDADE BRASILEIRA DE ZOOTECNIA, 38., Piracicaba, 2001. Anais. Piracicaba: SBZ, 2001. p. 967 - 968.

COWAN, R.T.; LOWE, K. F. Tropical and subtropical grass management and quality. In: CHERNEY, J. H.; CHERNEY, D. J. R. Grass for dairy cattle. Wallingford: $C A B, 1998$. cap. 5, p.101- 136. 
CROWDER, L. V.; CHHEDA, H. R. Tropical grassland husbandry. New York: Longman Tropical Agricultural Series, 1982. 562p.

CRUZ, G. M. da; RODRIGUES, A.A.; TULLIO, R. R.; ALENCAR, M. M.; CORDEIRO, C. A.; OlIVEIRA, G. P. de. Avaliação do desempenho de bezerros nelore e cruzados desmamados recebendo dois níveis de suplementação concentrada em pastagem de coastcross. In: REUNIÃO ANUAL DA SOCIEDADE BRASILEIRA DE ZOOTECNIA, 38., Piracicaba, 2001. Anais. Piracicaba: SBZ, 2001. p. 1181 - 1182.

DEL CURTO, T.; COCHRAN, R. C.; CORAH, L. R.; BEHARKA, A. A.; VANZANT, E. S.; JOHNSON, D. E. Supplementation of dormant tallgrassprairie forage. II. Performance and forage utilization characteristics in grazing beef cattle receiving supplements of different protein concentrations. Journal of Animal Science, v. 68, p. 532 - 542, 1990.

DETMANN, E.; PAULINO, M. F.; LANA, R. P. Fontes de proteína em suplementos múltiplos para terminação de bovinos em pastejo: $\mathrm{pH}$ e amônia ruminal (compact disc). In: REUNIÃO ANUAL DA SOCIEDADE BRASILEIRA DE ZOOTECNIA, 37., Viçosa, 2000. Anais. Viçosa: SBZ, 2000.

DETMANN, E.; PAULINO, M. F.; ZERVOUDAKIS, J. T.; VALADARES FILHO, S. C.; LANA, R. P.; QUEIROZ, D. S. de. Suplementação de novilhos mestiços durante a época das águas: parâmetros ingestivos e digestivos. Revista Brasileira de Zootecnia, v. 30, p. 1340 - 1349, 2001. 
DE VISSER, H.; KLOP, A.; VAN DER KOELEN, C. J.; VAN VUUREN, A. M. Starch supplementation of grass harvested at two stages of maturity prior to ensiling: intake, digestion, and degradability by dairy cows. Journal of Dairy Science, v. 81, p. $2221-2227,1998$.

DIFANTE, G. S.; MARCHEZAN, E.; MARZARI, V.; SEGABINAZI, T.; ROCHA, M. G. da. Produção de novilhos de corte suplementados em pastagens de inverno, submetida a doses de adubação nitrogenada em áreas de várzea. In: REUNIÃO ANUAL DA SOCIEDADE BRASILEIRA DE ZOOTECNIA, 38., Piracicaba, 2001. Anais. Piracicaba: SBZ, 2001. p. 375 - 376.

DIXON, R. M.; STOCKDALE, C. R. Associative effects between forages and grains: consequences for feed utilisation. Australian Journal of Agricultural Research, v. 50, p. 757-773, 1999.

ELIZALDE, J. C.; CREMIN Jr., J. D.; FAULKNER, D. B.; MERCHEN, N. R. Performance and digestion by steers grazing tall fescue and supplemented witth energy and protein. Journal of Animal Science, v. 76, p. 1691-1701, 1998.

ELIZALDE, J. C.; MERCHEN, N. R.; FAULKNER, D. B. Supplemental cracked corn for steers fed fresh alfalfa. II. Protein and amino acid digestion. Journal of Animal Science, v. 77, p. 467 - 475, 1999a.

ELIZALDE, J. C.; MERCHEN, N. R.; FAULKNER, D. B. Supplemental cracked corn for steers fed fresh alfalfa. I. Effects on digestion of organic matter, fiber, and starch. Journal of Animal Science, v. 77, p. 457 - 466, 1999 b. 
ERLINGER, L. L.; TOLLESON, D. R.; BROWN, C. J. Comparison of bite size, biting rate and grazing time of beef heifers from herds distinguished by mature size and rate of maturity. Journal of Animal Science, v. 68, p. 3578-3587, 1990.

EUCLIDES, V. P. B.; THIAGO, L. R. L. S.; MACEDO, M. C. M.; OLIVEIRA, M. P. de. Consumo voluntário de forragem de três cultivares de Panicum maximum sob pastejo. Revista Brasileira de Zootecnia, v. 28, p. 1177 1185, 1999.

FAHEY Jr.; G. C.; BERGER, L. L. Carbohydrate nutrition of ruminants. In: $\mathrm{CHURCH}$, D. C. (Ed.). The ruminant animal: digestive physiology and nutrition. New Jersey: Prentice Hall, 1988. cap. 14, p. 269 - 297.

FAIRBROTHER, T. E.; BRINK, G. E. Effect of energy and protein supplement on performance of steers grazing bermudagrass pastures. Journal of Animal Science, v. 69, suppl. 1, p. 225, 1991.

FORBES, J. M. Voluntary food intake and diet selection in farm animals. Wallingford: CAB, 1995. 532p.

FRANKLIN, K. K.; WINCH, J. E.; MaCLEOD, G. K. The effect of concentrate on the digestion of bromegrass constituents. Canadian Journal of Animal Science, v. 61, p. $935-944,1981$.

FUNK, M. A.; GAYLEAN, M. L.; BRANINE, M. E. Steers grazing blue grama rangeland throughout the growing season. II. Site and extent of digestion and microbial protein synthesis. Journal of Animal Science, v. 65, p. $1354-1361,1987$. 
GALLOWAY, D. L.; GOETSCH, L. A.; FORSTER Jr., L. A.; BRAKE, A. C.; JONHSON, Z. B. Digestion, feed intake, and live weight gain by cattle consuming bermudagrass and supplemented with different grains. Journal of Animal Science, v. 71, p. 1288 - 1297, 1993.

GEKARA, O. J.; PRIGGE, E. C.; BRYAN, W. B.; SCHETTINI, M.; NESTOR, E. L.; TOWNSEND, E. C. Influence of pasture sward height and concentrate supplementation on intake, digestibility, and grazing time of lactating beef cows. Journal of Animal Science, v. 79, p. 745 - 752, 2001.

GOERING, H. K.; VAN SOEST,P. J. Forage fiber analysis. Aparatus, reagents, procedures and some applications. Washington: USDA, 1970. 379p. (ARS Agricultural Handbook)

GRIGSBY, K. N.; KERLEY, M. S.; PATERSON, J. A.; WEIGEL, J. C. Combinations of starch and digestible fiber in supplements for steers consuming a low-quality bromegrass hay diet. Journal of Animal Science, v. 71, p. $1057-1064,1993$.

HADDAD, S.G.; GRANT, R. J. Influence of nonfiber carbohydrate concentration on forage fiber digestion in vitro. Animal Feed Science and Technology, v. 86, p. $107-115,2000$.

HAFLEY, J. L.; ANDERSON, B. E.; KLOPFENSTEIN, T. J. Supplementation of growing cattle grazing warm-season grass with proteins of various ruminal degradabilities. Journal of Animal Science, v. 71, p. 522-529, 1993. 
HARMISON, B.; EASTRIDGE, M. L.; FIRKINS, J. L. Effect of percentage of dietary forage neutral detergent fiber and source of starch on performance of lactating Jersey cows. Journal of Dairy Science, v. 80, p. $905-911$, 1997.

HELDT, J. S.; PRUITT, R. J.; BIRKELO, C. P.; JOHNSON, P. S.; WICKS III, Z. W. Evaluation of wheat middlings as a supplement for beef cows grazing native range with differing forage availabilities. Journal of Animal Science, v. 76, p. $378-387,1998$.

HELDT, J. S.; COCHRAN, R. C.; MATHIS, C. P.; WOODS, B. C.; OLSON, K. C., TITGEMEYER, E. C.; NAGARAJA, T. G.; VANZANT, E. S.; JOHNSON, D. E. Effects of level and source of carbohydrate and level of degradable intake protein on intake and digestion of low-quality tallgrass-prairie hay by beef steers. Journal of Animal Science, v. 77, p. 2846 - 2854, 1999.

HENNING, P. A.; VAN DER LINDEN, Y.; MATTHEYSE, M. E.; NAUHAUS, W. K.; SCHUWARTZ, H. M.; GILCHRIST, F. M. Factors affecting the intake and digestion of roughage by sheep fed maize straw supplemented with maize grain. Journal of Agricultural Science, v. 94, p. 565 - 573, 1980.

HESS, B. W.; KRYSL, L. J.; JUDKINS, M. B.; HOLCOMBE, D. W.; HESS, J. D.; HANKS, D. R.; HUBER, S. A. Supplemental cracked corn or wheat bran for steers grazing endophyte-free fescue pasture: effects on live weight gain, nutrient quality, forage intake, particulate and fluid kinetics, ruminal fermentation, and digestion. Journal of Animal Science, v. 74, p. 1116 1125, 1996.

HODGSON, J. Grazing management: science into practice. Essex: Longman, 1990. 203 p. 
HOGAN, J. P. Digestion and utilisation of proteins. In: HACKER, J. B. (Ed.). Nutritional limits to animal production from pastures. Farnham Royal: CAB, 1982. p. $245-257$.

HOLDEN, L. A. Comparison of methods of in vitro dry matter digestibility for ten feeds. Journal of Dairy Science, v. 82, p, 1791 - 1794, 1999.

HOOVER, W. H. Chemical factors involved in fiber digestion. Journal of Dairy Science, v. 69, p. 2755 - 2766, 1986.

HUMPHREYS, L. R. Tropical pasture utilisation. Cambridge: Cambridge University Press, 1991. 205p.

HUNTINGTON, G. B.; PRIOR, R. L.; BRITTON, R. A. Glucose and lactate absorption and metabolic interrelationships in steers changed from low to high concentrate diets. Journal of Nutrition, v. 111, p. 1164, 1981.

JAMIESON, W. S.; HODGSON, J. The effect of daily herbage allowance and sward characteristics upon the ingestive behavior and herbage intake of calves under strip-grazing management. Grass and Forage Science, v. 34, p. $261,1979$.

JONES, A. L.; GOETSCH, A. L.; STOKES, S. R.; COLBERG, M. Intake and digestion in cattle fed warm or cool-season grass hay with or without supplemental grain. Journal of Animal Science, v. 66, p. 194-203, 1988.

JOY, M. T.; De PETERS, J.; FADEL, J. G.; ZINN, R. A. Effects of corn processing on the site and extent of digestion in lactating cows. Journal of Dairy Science, v. 80, p. 2087 - 2097, 1997. 
JUNG, H. G.; FAHEY Jr.; G. C. Influence of phenolic acids on forage structural carbohydrate digestion. Canadian Journal of Animal Science, v. 64, Suppl. 1, p. 50, 1984.

KARGES, K. K.; KLOPFENSTEIN, T. J.; WILKERSON, V. A; CLANTON, D. C. Effects of ruminally degradable and escape protein supplements on steers grazing summer native range. Journal of Animal Science, v. 70, p. 19571964, 1992.

KEMALYAN, R.E.; ROUQUETTE Jr., F.M.; FLORENCE, M. J.; ELLIS, W. C.; HUTCHESON, D. P. Effect of self-limiting corn-based supplement on performance of calves grazing rye-grass pastures. Journal of Animal Science, v. 69, Suppl. 1, p. 225, 1991.

KÖSTER, H. H.; COCHRAN, R. C.; TITGEMEYER, E. C.; VANZANT, E. S.; ABDELGADIR, I.; ST-JEAN, G. Effect of increasing degradable intake protein on intake and digestion of low-quality, tall-grass-prairie forage by beef cows. Journal of Animal Sciense, v. 74, p. 2473 - 2481, 1996.

KRYSHNAMOORTHY, U.; SNIFFEN, C.J.; STERN, M. D.; VAN SOEST, P. J. Evaluation of a mathematical model of rumen digestion and in vitro simulation od rumen proteolysis to estimate teh rumen-undegraded nitrogen content od feedstufs. British Journal of Nutrition, v. 50, p. $555-568$, 1983.

KRYSL, L. J.; HESS, B. W. Influence of supplementation on behavior of grazing cattle. Journal of Animal Science, v. 71, p. 2546-2555, 1993. 
KRYSL, L. J.; BRANINE, M. E.; CHEEMA, A U.; FUNK, M. A; GALYEAN, M. L. Influence of soybean meal and sorghum grain supplementation on intake, digesta kinetics, ruminal fermentation, site and extent of digestion and microbial protein synthesis in beef steers grazing blue grama rangeland. Journal of Animal Science, v. 67, p.3040-3051, 1989.

LENG, R. A. Factors affecting the utilization of poor quality forages by ruminants particularly under tropical conditions. Nutrition Research Reviews, v. 3, p. 277-303, 1990.

LEVENTINI, M. W.; HUNT, C. W.; ROFFLER, R. E.; CASEBOLT, D. G. Effect of dietary level of barley-based supplements and ruminal buffer on digestion and growth by beef cattle. Journal of Animal Science, v. 68, p. 4334 4344, 1990.

LIMA, L. G. de. Local, taxa e extensão da digestão de nutrientes em rações para vacas leiteiras com base em capim elefante (Pennisetum purpureum, Schum cv cameron) suplementadas com fontes e níveis de energia e proteina. Piracicaba, 2000. 99 p. Dissertação (Mestrado) - Escola Superior de Agricultura "Luiz de Queiroz", Universidade de São Paulo.

LIMA, N. C.; SIMILI, F. F.; LIMA, M. L. P.; SANTOS, A. L. dos; ROMA JR.; L. C.; LEME, P. R.; BERCHIELLI, T. T.; PINHEIRO, M. G.; NOGUEIRA, J. R. Tempo de pastejo de vacas mestiças em sistema rotacionado de capim Tanzânia (Panicum maximum) ou capim-elefante (Pennisetum purpureum). In: REUNIÃO ANUAL DA SOCIEDADE BRASILEIRA DE ZOOTECNIA, 37., Viçosa, 2000. Anais. Viçosa: SBZ, 2000. p. 16. 
LODMAN, D. W.; PETERSEN, M. K.; CLARCK, C. K.; WILEY, J. S.; HAVSTAD, K. M.; McINERNEY, M. J. Substitution of DL-methionine for soybean meal as a winter supplement for gestating cows grazing native range. Journal of Animal Science, v. 68, p. 4361 - 4375, 1990.

LYKOS, T.; VARGA, G. A.; CASPER, D. Varying degradation rates of total nonstructural carbohydrates. Effects on ruminal fermentation, blood metabolites and milk production and composition in high producing holstein cows. Journal of Dairy Science, v. 80, p. 3341 - 3355, 1997.

MARCONDES, P. F.; ALVES, J. B.; ISEPON, O. J.; BERGAMASCHINE, A. F. Desempenho de bovinos em pastagens de Brachiaria decumbens suplementados com proteína e energia no período das águas. In: REUNIÃO ANUAL DA SOCIEDADE BRASILEIRA DE ZOOTECNIA, 38., Piracicaba, 2001. Anais. Piracicaba: SBZ, 2001. p. 1229 - 1231.

MATEJOVSKY, K. M.; SANSON, D.W. Intake and digestion of low-, medium-, and high quality grass hays by lambs receiving increasing levels of com supplementation. Journal of Animal Science, v. 73, p. 2156 - 2163, 1995.

MATHIS, C. P.; COCHRAN, R. C.; HELDT, J. S.; WOODS, B. C.; ABDELGADIR, I. E. O.; OLSON, K. C.; TITGEMEYER, E. C.; VANZANT, E. $S$. Effects of supplemental degradable intake protein on utilization of medium to low-quality forages. Journal of Animal Science, v. 78, p. 224 232, 2000.

McCOLLUM, F. T.; GALYEAN, M. L. Influence of cottonseed meal supplementation on voluntary intake, rumen fermentation and rate of passage of prairie hay in beef steers. Journal of Animal Science, v. 60, p. $570-577,1985$. 
MENEZES Jr., M. P. Efeito do processamento do grão de milho e sua substituição parcial por polpa de citros peletizada sobre o desempenho, digestibilidade de nutrientes e parâmetros sanguíneos de vacas de leite. Piracicaba, 1999. 97p. Dissertação (Mestrado) - Escola Superior de Agricultura "Luiz de Queiroz", Universidade de São Paulo.

MERCHEN, N. R. Digestión, absorción y excreción en los ruminantes. In: $\mathrm{CHURCH}$, D. C. (Ed.). El rumiante: fisiología digestiva y nutrición. Zaragoza: Editorial Acribia, 1993 cap. 9, p. 191 - 223.

MERTENS, D. R. Predicting intake and digestibility using mathematical models of ruminal function. Journal of Animal Science, v. 64, p. 1548 - 1558, 1987.

MERTENS, D. R. Nonstructural and structural carbohydrates. In: VAN HORN, H. H.; WILCOX, C. J. (Ed.). Large dairy herd management. Champaing: American Dairy Science Association, 1992. cap. 25, p. 219 - 235.

MERTENS, D. R. Regulation of forage intake. In: FAHEY Jr., G. C.; MOSER, L. E.; MERTENS, D. R.; COLLINS, M. (Ed.). Forage quality, evaluation and utilization. Madison: ASA; CSSA; SSSA, 1994. cap. 11, p. 450-493.

MERTENS, D. R. Creating a system for meating the fiber requirements of dairy cows. Journal of Dairy Science, v. 80, p. $1463-1481,1997$.

MERTENS, D. R.; ELY, L. O. Relationship of rate and extent of digestion to forage utilization. A dynamic model evaluation. Journal of Animal Science, v. 54 , p. $895-905,1982$. 
MERTENS, D. R.; LOFTEN, J. R. The effects of starch on forage fiber digestion kinetics in vitro. Journal of Dairy Science, v. 63, p. 1437, 1980.

MINSON, D. J. Forages in ruminant nutrition. New York: Academic Press, 1990. 483p.

NATIONAL RESEARCH COUNCIL. Nutrient requirements of dairy cattle. 6.ed. Washington: National Academy of Sciences,1989. 157p.

NATIONAL RESEARCH COUNCIL. Nutrient requirements of beef cattle. 7. ed. Washington: National Academy of Sciences, 1996. 242p.

NATIONAL RESEARCH COUNCIL. Nutrient requirements of dairy cattle. 7.ed. Washington: National Academy of Sciences, 2001. 381p.

NOLLER, C. H. Nutritional requirements of grazing animal. In: INTERNATIONAL SYMPOSIUM ON ANIMAL PRODUCTION UNDER GRAZING, Viçosa, 1997. Proceedings. Viçosa: UFV, 1997. p. 145-172.

NUSSIO, L. G. Effects on NDF levels and ruminally degradable starch on performance, ruminal parameters and in situ degradation of nutrients in lactating dairy cows fed sorghum diets. Tucson, 1997. 139 p. Thesis (Ph.D.) - University of Arizona.

NUSSIO, L. G.; MANZANO, R. P.; PEDREIRA, C. G. S. Valor alimentício em plantas do gênero Cynodon. In: SIMPÓSIO SOBRE MANEJO DA PASTAGEM, 15., Piracicaba, 1998. Manejo de pastagens de Tifton, Coastcross e Estrela: anais. Piracicaba: FEALQ, 1998. p. 203 - 242. 
OBARA, Y.; DELLOW, D. W.; NOLAN, J. V. The influence of energy-rich supplements on nitrogen kinetics in ruminants. In: TSUDA, T.; SASAKI, Y.; KAWASHIMA, R. (Ed.) Physiological aspects of digestion and metabolism in ruminants. New York:Acadmeic Press, 1991. p. 515-539.

OLSON, K. C.; COCHRAN, R. C.; JONES, T. J.; VANZANT, E. S.; TITGEMEYER, E. C.; JOHNSON, D. E. Effects of ruminal administration of supplemental degradable intake protein and starch on utilization of lowquality warm-season grass hay by beef steers. Journal of Animal Science, v. 77, p. 1016 - 1025, 1999.

OPATPATANAKIT, Y.; KELLAWAY, R. C.; LEAN, I. J.; ANNISON, G.; KIRBY, A. Effects of cereal grains on fibre digestion in vivo. Australian Journal of Agricultural Research, v. 46, p. $403-413,1995$.

ORSKOV, E. R. Nutrición proteica de los ruminantes. Zaragoza: Ed. Acribia, 1988. $178 \mathrm{p}$.

ORSKOV, E. R.; McDONALD, I. The estimation of protein degradability in the rumen from incubation measurements weighed according to rate of passage. Journal of Agricultural Science, v. 92, p. 499 - 503, 1979.

ORSKOV, E. R.; REID, G. W.; KAY, M. Prediction of intake by cattle from degradation characteritics of roughages. Animal Production, v. 46, p. 29 34, 1988.

PALMQUIST, D. L.; CONRAD, H. R. Origin of plasma fatty acids in lactating cows fed high grain fat diets. Journal of Dairy Science, v. 54, p. 1025 , 1971. 
PATERSON, J. A.; BELYEA, R.L.; BOWMAN, J. B., KERLEY, M. S., WILLIAMS, $J$ J. The impact of forage quality and supplementation regimen on ruminant animal intake and performance. In: FAHEY Jr., G. C.; MOSER, L. E.; MERTENS, D. R.; COLLINS, M. (Ed.) Forage, quality, evaluation and utilization. Madison: ASA; CSSA; SSSA, 1994. cap. 2, p. 59 - 114.

PENATI, M. A. Estudo do desempenho animal e produção do capim Tanzânia (Panicum maximum Jacq.) em um sistema rotacionado de pastejo sob irrigação em três niveis de residuo pós pastejo. Piracicaba, 2002. Tese (Doutorado) - Escola Superior de Agricultura "Luiz de Queiroz". Universidade de São Paulo (no prelo).

PERRY, T. W.; HUBER, D. A; MOTT, G. O.O.; RHYKERD, C. L.; TAYLOR, R. W. Effect of level of pasture supplementation on pasture, drylot and total performance of beef cattle. II. Spring plus summer pasture. Journal of Animal Science, v. 34, p. 647-652, 1972.

POORE, M. H.; ECK, T. P.; SWINGLE, R. S.; THEURER, C. B. Total starch and relative starch availability of feed grains. In: BIENNAL CONFERENCE ON RUMEN FUNCTION, 20. Chicago, USDA, 1989. Abstracts.

POPPI, D. P.; McLENNAN, S. R. Protein and energy utilisation by ruminants at pasture. Journal of Animal Science, v. 73, p. 278 - 290, 1995.

POPPI, D. P.; HUGHES, T. P.; L'HUILLIER, P. J. Intake of pasture by grazing ruminants. In: New Zealand Society of Animal Science. Livestock feeding pasture. Wellington: New Zealand Society of Animal Production, 1987. cap. 4, p. $55-63$. 
PORDOMINGO, A J.; WALLACE, J. D.; FREEMAN, A S.; GALYEAN, M. L. Supplemental corn grain for steers grazing native rangeland during summer. Journal of Animal Science, v. 69, p.1678-1687, 1991.

PROHMANN, P. E. F.; BRANCO, A. F.; CECATO, U.; JOBIM, C. C.; GUIMARÃES, C. C.; SARTI, L.; HOESCHL, A. R.; CANO, C. P. Efeitos da suplementação energética no verão sobre o desenvolvimento de novilhos precoces. In: REUNIÃO ANUAL DA SOCIEDADE BRASILEIRA DE ZOOTECNIA, 38., Piracicaba, 2001. Anais. Piracicaba: SBZ, 2001. p. $1286-1287$.

REARTE, D. H.; PIERONI, G. A. Supplementation of temperate pastures. In: INTERNATIONAL GRASSLAND CONGRESS, 19, São Pedro, 2001. Anais. Piracicaba:FEALQ, 2001. p. 679 - 689.

RIBEIRO FILHO, H. M. N.; APZTEGUIA, E. S.; ALMEIDA, E. X. de; MARASCHIN, G. E. Comportamento ingestivo e parâmetros ruminais de novilhos em capim elefante anão "Mott" (Pennisetum purpureum, Shum) com quatro doses de nitrogênio sob pastejo. (compact disc). In: REUNIÃO ANUAL DA SOCIEDADE BRASILEIRA DE ZOOTECNIA, 36., Porto Alegre, 1999. Anais. Porto Alegre: SBZ, 1999.

RIBEIRO FILHO, H. M. N.; ALMEIDA, E. X. de; HARTHMANN, O. E. L.; MARASCHIN, G. E.; RIBEIRO, S. R. Consumo de forragem de bovinos submetidos a diferentes ofertas de capim-elefante anão cv. "Mott". In: REUNIÃO ANUAL DA SOCIEDADE BRASILEIRA DE ZOOTECNIA, 34., Juiz de Fora, 1997. Anais. Juiz de Fora: SBZ, 1997. p. 274-275. 
ROONEY, L. W.; PFLUGFELDER, R. L. Factors affecting starch digestibility with special emphasis on sorghum and corn. Journal of Animal Science, v. 63, p. $1607-1623,1986$.

ROSA, B.; REIS, R. A.; RESENDE, K. T. de; JOBIM, C. C. RODRIGUES, L. R. A. Degradabilidade in situ do feno de Brachiaria decumbens Stapf cv. Basilisk amonizado. In: REUNIÃO ANUAL DA SOCIEDADE BRASILEIRA DE ZOOTECNIA, 33., Fortaieza, 1996. Anais. Fortaleza : SBZ, 1996. p. 324 -326 .

SANSON, D. W.; CLANTON, D. C.; RUSH, I. G. Intake and digestion of lowquality meadow hay by steers and performance of cows on native range when fed protein supplements containing various levels of corn. Journal of Animal Science, v. 68, p. 595-603, 1990.

SAS INSTITUTE. SAS: users guide; statistics. 5.ed. Cary, 1991. 213p.

SATTER, L. D.; SLYTER, L. L. Effect of ammonia concentration on rumen microbial protein production in vitro. British Journal of Nutrition, v. 32, p. $199-208,1974$.

SIMAS, J. M. C. Effect of sorghum grain processing and fat supplementation on performance and nutrient utilization in lactating dairy cows. Tucson, 1995. 147p. Thesis (Ph.D.) - Universtiy of Arizona.

SORIANO, F. D.; POLAN, C. E.; MILLER, C. N. Milk production and composition, rumen fermentation parameters and grazing behavior of dairy cows supplemented with different forms and amounts of corn grain. Journal of Dairy Science, v. 83, p. 1520 - 1529, 2000. 
STAKELUM, G.; LIEVENSE, P.; GLEESON, P. A. The relationship between the social dominance of cows in a grazing herd and their milk production, herbage intake and grazing behaviour. Irish Journal of Agricultural Research, v. 26, p. $231-235,1987$.

STOBBS, T. H. The effect of plant structure on intake of tropical pastures. I. Variation in the bite size of grazing cattle. Australian Journal of Agricultural Research, v. 24, p. $809-819,1973 a$.

STOBBS, T. H. The effect of plant structure on intake of tropical pastures. II. Differences in sward structure, nutritive value, and bite size of animals grazing Setaria anceps and Chloris gayana at various stages of growth. Australian Journal of Agricultural Research, v. 24, p. 821 - 829, $1973 b$.

SUTTON, J. D.; BINES, J. A.; MORATI, S. V.; NAPPER, D. J. A comparasion of starch and fibrous concentrate for milk production, energy utilization and hay intake by friesian cows. Journal of Agricultural Science, v. 109, p. $375-$ 386, 1987.

THEURER, B. C. Grain processing effects on starch utilization by ruminants. Journal of Animal Science, v. 63, p. 1649- 1662, 1986.

THEURER, B. C.; HUBER, J. T.; DELGADO-ELORDUY, A. Steam-flaking improves starch utilization and milk production parameters. In: CORNELL NUTRITION CONFERENCE FOR FEED MANUFACTURERS, Rochester, 1996. Proceedings. Ithaca: Cornell University, 1996. p. 121 - 130. 
THEURER, B. C.; HUBER, J. T.; DELGADO-ELOURDY A.; WANDERLEY, R. Invited Review: Summary of steam-flaking corn or sorghum grain for lactating dairy cows. Journal of Dairy Science, v. 82, p. $1950-1959$, 1999.

THIAGO, L. R. L. S.; GILL, M. Consumo voluntário de forragens por ruminantes: mecanismo físico ou fisiológico. In: SOCIEDADE BRASILEIRA DE ZOOTECNIA. Bovinocultura de corte. Piracicaba: FEALQ, 1990. p. 47 77.

THIAGO, L. R. L. S.; EUCLIDES, V. P. B.; NICODEMO, M. L. F.; CARVALHO, J. Estudos sobre a degradação e remoção da matéria seca do rúmen de bovinos. In: REUNIÃO ANUAL DA SOCIEDADE BRASILEIRA DE ZOOTECNIA, 28., João Pessoa, 1991. Anais. João Pessoa, SBZ, 1991. p. 228.

VAN SOEST, P. J.; ROBERTSON, J. B.; LEWIS, B. A. Methods for dietary fiber, neutral detergent fiber, and nonstarch polissacharides in relation to animal nutrition. Journal of Dairy Science, v. 74, p. 3583 - 3591, 1991.

VAN SOEST, P. J. Nutritional ecology of ruminant. Ithaca: Cornell University Press, 1994. 476p.

VANZANT, E. S.; COCHRAN, R. C.; JACQUES, K. A.; BEHARKA, A. A.; DELCURTO, T.; AVERY, T. B. Influence of level of supplementation on type of grain in supplements on intake and utilization of harvested, early-growingseason, bluestem-range forage by beef steers. Journal of Animal Science, v. 68 , p. 1457-1468, 1990. 
VIEIRA, R. A. M.; PERERIA, J. C.; QUEIROZ, A. C. de; NASCIMENTO JR., D. do; VALADARES FILHO, S. de C.; MALAFAIA, P. A. M. Estimativa da digestibilidade ruminal do capim elefante a partir de ensaios de degradação in situ e in vitro. In: REUNIÃO ANUAL DA SOCIEDADE BRASILEIRA DE ZOOTECNIA, 33., Fortaleza, 1996. Anais. Fortaleza:SBZ, 1996. p. 297 299.

WEISS, W. P.; CONRAD, H. R.; PIERRE, N. R. S. A theoretically-based model for predicting total digestible nutrient values of forages and concentrates. Animal Feed Science and Technology, v. 39, p. 95 - 110, 1992.

WEISS, W. P. Estimation of digestibility of forages by laboratory methods. In: FAHEY Jr., G. C.; MOSER, L. E.; MERTENS, D. R.; COLLINS, M. (Ed.). Forage quality, evaluation and utilization. Madison: ASA;CSSA;SSSA, 1994. cap. 16 , p. $644-681$.

WILES, P. G.; GRAY, I. K.; KISSILING, R. C. Routine analysis of protein by Kjeldhal and Dumas methods: Review and interlaboratory study using dairy products. Journal of A. O. A. C. International, v. 81, p. $620-632,1998$.

WORREL, M. A.; UNDERSANDER, D. J.; THOMPSON, C. E.; BRIDGES JR, W. C. Effects of time of season and cottonseed meal and lasalocid supplementation on steers grazing rye pastures. Journal of Animal Science, v. 68, p. $1151-1157,1990$.

YOKOYAMA, M. T.; JOHNSON, K. A. Microbiologia del rumen y intestino. In: $\mathrm{CHURCH}$, C. D. (Ed.) El ruminante: fisiologia digestiva y nutrición. Zaragoza: Ed. Acribia, 1993. cap. 7, p. 137-157. 